\title{
"The Rule of Love": Wife Beating as Prerogative and Privacy
}

Reva B. Siegel ${ }^{\dagger}$

\author{
CONTENTS
}

INTRODUCTION $\ldots \ldots \ldots \ldots \ldots \ldots \ldots \ldots \ldots \ldots \ldots \ldots \ldots \ldots \ldots \ldots$

I. NINETEENTH-CENTURY ABOLITION OF

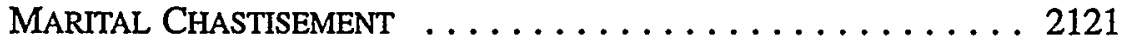

A. The Right of Chastisement and Its Critics . . . . . . . 2122

B. Formal Repudiation of the Right of Chastisement ...... 2129

1. Relief for Battered Wives: Separation and Divorce . . . . 2130

2. Race and Class Bias in the Criminal Prosecution of Wife Beaters ...................... 2134

II. REgUlating MaRital VIOLENCE IN AN ERA OF

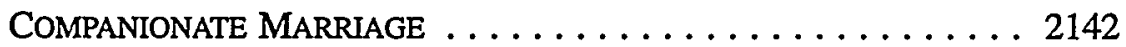

III. The Discourse of AfFective PRivacy IN DOMestic AsSAULt LAW ....................... 2150

A. Marital Violence and Marital Privacy in the Criminal Law ..................... 2154

B. Affective Privacy in the Emerging Law of Interspousal Tort Immunity . . . . . . . . . . . . . . . . 2161

C. A Brief Reprise: Marital Privacy in the Criminal Law of the Twentieth Century ................. 2170

$\dagger$ Professor of Law, Yale Law School. I am grateful to Bruce Ackerman and Robert Post and many other friends and colleagues who commented on the manuscript in its various stages of development: Akhil Amar, Jack Balkin, Hugh Baxter, James Boyle, Mary Anne Case, Nancy Cott, William Eskridge, Thomas Ferraro, Owen Fiss, Paul Gewirtz, Sally Goldfarb, Julie Goldscheid, Robert Gordon, Anthony Kronman, Lawrence Lessig, Martha Minow, Victoria Nourse, Lisa Orsaba, Joel Paul, Joel Pfister, Milton Regan, Judith Resnik, Dorothy Roberts, Austin Sarat, Derick Schilling, William Treanor, Lea VanderVelde, Laura Wexler, Joan Williams, and participants in faculty workshops at the Yale Law School, Harvard Law School, and American College of Law. In writing this Article, I was fortunate to have the assistance of Lisa Cardyn, who devoted many hours of research to the project and was always willing to engage the critical premises of my argument; Johanna Shargel and Catherine Lhamon also contributed significant research support. 
IV. CIVIL RIGHTS REFORM AND THE MODERNIZATION OF

STATUS Discourse . . . . . . . . . . . . . . . . . 2174

A. Historical Perspectives ................... 2175

B. Contemporary Perspectives ................ 2188

C. Discourses of Affective Privacy Today: Interpreting the

Violence Against Women Act . . . . . . . . . . . . . . . 2196

1. VAWA's Civil Rights Remedy for

Gender-Motivated Violence . . . . . . . . . . . . 2197

2. VAWA: Rule of Love Redux . . . . . . . . . . . . 2200

CONCLUSION ............................ 2206

\section{INTRODUCTION}

The Anglo-American common law originally provided that a husband, as master of his household, could subject his wife to corporal punishment or "chastisement" so long as he did not inflict permanent injury upon her. ${ }^{1}$ During the nineteenth century, an era of feminist agitation for reform of marriage law, authorities in England and the United States declared that a husband no longer had the right to chastise his wife. ${ }^{2}$ Yet, for a century after courts repudiated the right of chastisement, the American legal system continued to treat wife beating differently from other cases of assault and battery. While authorities denied that a husband had the right to beat his wife, they intervened only intermittently in cases of marital violence: Men who assaulted their wives were often granted formal and informal immunities from prosecution, in order to protect the privacy of the family and to promote "domestic harmony."3 In the late 1970s, the feminist movement began to challenge the concept of family privacy that shielded wife abuse, and since then, it has secured many reforms designed to protect women from marital violence. ${ }^{4}$ Yet violence in the household persists. The U.S. Surgeon General recently found that "battering of women by husbands, ex-husbands or lovers '[is] the single largest cause of injury to women in the United States."

1. See infra Section I.A.

2. See infra Section I.B. For some accounts of law reform in England during the late nineteenth century, see A. JAMES HAMMERTON, CRUELTY AND COMPANIONSHIP: CONFLICT IN NINETEENTH-CENTURY MARRIED LIFE 52-67 (1992); Carol Bauer \& Lawrence Ritt, "A Husband is a Beating Animal": Frances Power Cobbe Confronts the Wife-Abuse Problem in Victorian England, 6 INT'L J. WOMEN's STUD. 99 (1983); Carol Bauer \& Lawrence Ritt, Wife-Abuse, Late-Victorian English Feminists, and the Legacy of Frances Power Cobbe, 6 INT'L J. WOMEN's STUD. 195 (1983).

3. See infra Part III.

4. See, e.g., Elizabeth M. Schneider, The Violence of Privacy, 23 CoNN. L. REV. 973 (1991).

5. Joan Zorza, The Criminal Law of Misdemeanor Domestic Violence, 1970-1990, 83 J. CRIM. L. \& CriminologY 46, 46 (1992) (quoting Nikki R. Van Hightower \& Susan A. McManus, Limits of State 
"[T]hirty-one percent of all women murdered in America are killed by their husbands, ex-husbands, or lovers."

The persistence of domestic violence raises important questions about the nature of the legal reforms that abrogated the chastisement prerogative. By examining how regulation of marital violence evolved after the state denied men the privilege of beating their wives, we can learn much about the ways in which civil rights reform changes a body of status law. In the nineteenth century, and again in the twentieth century, the American feminist movement has attempted to reform the law of marriage to secure for wives equality with their husbands. Its efforts in each century have produced significant changes in the law of marriage. The status of married women has improved, but wives still have not attained equality with their husbands-if we measure equality as the dignitary and material "goods" associated with the wealth wives control, or the kinds of work they perform, or the degree of physical security they enjoy. Despite the efforts of the feminist movement, the legal system continues to play an important role in perpetuating these status differences, although, over time, the role law plays in enforcing status relations has become increasingly less visible.

As this Article will show, efforts to reform a status regime do bring about change-but not always the kind of change advocates seek. When the legitimacy of a status regime is successfully contested, lawmakers and jurists will both cede and defend status privileges-gradually relinquishing the original rules and justificatory rhetoric of the contested regime and finding new rules and reasons to protect such status privileges as they choose to defend. Thus, civil rights reform can breathe new life into a body of status law, by pressuring legal elites to translate it into a more contemporary, and less controversial, social idiom. ${ }^{7}$ I call this kind of change in the rules and rhetoric of a status regime "preservation through transformation," and illustrate this modernization dynamic in a case study of domestic assault law as it evolved in rule structure and rationale from a law of marital prerogative to a law of marital privacy.

Parts I-III of this Article illustrate that as the nineteenth-century feminist movement protested a husband's marital prerogatives, the movement helped bring about the repudiation of chastisement doctrine; but, in so doing, the movement also precipitated changes in the regulation of marital violence that "modernized" this body of status law. A survey of criminal and tort law regulating marital violence during the Reconstruction Era reveals that the American legal system did not simply internalize norms of sex equality

Constitutional Guarantees: Lessons from Efforts to Implement Domestic Violence Policies, 49 PUB. ADMIN. REv. 269, 269 (1989)).

6. Zorza, supra note 5 , at 46 . For a more extended account of recent domestic violence statistics, see infra text accompanying notes 199-211.

7. See infra Section IV.A. 
espoused by feminist critics of the chastisement prerogative; instead, during the Reconstruction Era, chastisement law was supplanted by a new body of marital violence policies that were premised on a variety of gender-, race-, and classbased assumptions. This new body of common law differed from chastisement doctrine, both in rule structure and rhetoric. Judges no longer insisted that a husband had the legal prerogative to beat his wife; instead, they often asserted that the legal system should not interfere in cases of wife beating, in order to protect the privacy of the marriage relationship and to promote domestic harmony. Judges most often invoked considerations of marital privacy when contemplating the prosecution of middle- and upper-class men for wife beating. Thus, as I show, the body of formal and informal immunity rules that sprang up in criminal and tort law during the Reconstruction Era was both genderand class-salient: It functioned to preserve authority relations between husband and wife, and among men of different social classes as well. ${ }^{8}$

These changes in the rule structure of marital status law were justified in a distinctive rhetoric: one that diverged from the traditional idiom of chastisement doctrine. Instead of reasoning about marriage in the older, hierarchy-based norms of the common law, jurists began to justify the regulation of domestic violence in the language of privacy and love associated with companionate marriage in the industrial era. Jurists reasoning in this discourse of "affective privacy" progressively abandoned tropes of hierarchy and began to employ tropes of interiority to describe the marriage relationship, justifying the new regime of common law immunity rules in languages that invoked the feelings and spaces of domesticity. Once translated from an antiquated to a more contemporary gender idiom, the state's justification for treating wife beating differently from other kinds of assault seemed reasonable in ways the law of chastisement did not. ${ }^{9}$

As the history of domestic violence law illustrates, political opposition to a status regime may bring about changes that improve the welfare of subordinated groups. With the demise of chastisement law, the situation of married women improved - certainly, in dignitary terms, and perhaps materially as well. At the same time, the story of chastisement's demise suggests that there is a price for such dignitary and material gains as civil rights reform may bring. If a reform movement is at all successful in advancing its justice claims, it will bring pressure to bear on lawmakers to rationalize status-enforcing state action in new and less socially controversial terms. This process of adaptation can actually revitalize a body of status law, enhancing its capacity to legitimate social inequalities that remain among status-differentiated groups. Examined from this perspective, the reform of chastisement doctrine can teach us much about the dilemmas confronting movements for social justice in America today.

8. See infra Subsection I.B.2 and Section III.A.

9. See infra Sections III.A-B. 
With these concerns in mind, Part IV of this Article offers some reflections on the ways in which civil rights reform modernizes the structure of a status regime. Drawing on the account of chastisement's demise explored in the main body of the Article, I first explore the question from a historical standpoint, and then briefly examine the implications of this analysis for understanding the civil rights revolutions of the 1960 s and $1970 \mathrm{~s}^{10}$ Finally, I bring the substantive and methodological concerns of the Article to bear on the most recent civil rights reform affecting the regulation of domestic violence today: the Violence Against Women Act," which provides a civil rights cause of action for victims of gender-motivated violence. The new federal statute treats intimate assaults such as rape and domestic violence as a problem of sex discrimination. But its scope has been sharply contested, raising questions about which acts of rape and domestic violence will be deemed "gender-motivated" within the meaning of the Act. By exploring conflicts over the new civil rights cause of action, I offer contemporary evidence that the rules and rhetoric governing intimate assaults are continuing to evolve in the face of recent civil rights initiatives. ${ }^{12}$ In this analysis of the Violence Against Women Act, as throughout the Article, I seek to demonstrate why, if civil rights reform is to be effective, civil rights law must remain in critical dialogue with the evolving discourse of any status regime it aspires to disestablish.

\section{NINETEENTH-CENTURY ABOLITION OF MARITAL CHASTISEMENT}

By the old law, a husband might give his wife moderate correction ... but it is declared in black and white that he may not beat her black and blue, though the civil law allowed any man on whom a woman had bestowed her hand, to bestow his fists upon her at his own discretion. The common people, who are much attached to the common law, still exert the privilege of beating their wives ... and a woman in the lower ranks of life, if she falls in love with a man, is liable, after marriage, to be a good deal struck by him.

Gilbert Abbott À Beckett, The Comic Blackstone (1869) ${ }^{13}$

Judge Blackstone ... published his commentaries above one hundred years ago, when society was much more rude . . . than it is at the present day in this country; and the exercise of a rude privilege there is no excuse for a like privilege here.... The wife is not to be considered as the husband's slave. And the privilege, ancient though it be, to beat her with a stick, to pull her hair, choke her, spit in her

10. See infra Sections IV.A-B.

11. 42 U.S.C.A. § 13981 (West 1995).

12. See infra Section IV.C.

13. Gilbert ABbott À Beckett, The Comic Blackstone 121-22 (Chicago, Callaghan \& Cockroft 1869) (1846) 
face or kick her about the floor, or to inflict upon her like indignities, is not now acknowledged by our law.

Fulgham v. State (Alabama 1871) $)^{14}$

In the nineteenth century, a husband's prerogative to chastise his wife was discussed in tones both jocose and solemn, uneasy and outraged.$^{15}$ Underlying most conversation about the prerogative was a common assumption, articulated more frequently with the passage of time: that marital chastisement was a vestige of another world, an ancient legal precedent of increasingly uncertain legitimacy. Yet, precisely by reason of its lineage as an ancient prerogative of marriage, chastisement did not die an easy death. In the following sections, I situate the prerogative in the marital status regime of the common law, and then trace the evolving social mores and diverse forms of political protest that precipitated its doctrinal demise. I then examine in more detail two cases repudiating the prerogative in 1871 , one from Massachusetts and the other from Alabama, in order to explore attitudes toward marital violence in this period. As this inquiry illustrates, a variety of gender-, class-, and race-based concerns shaped the regulation of marital violence during the Reconstruction Era, evidence that draws into question the social meaning of chastisement's demise.

\section{A. The Right of Chastisement and Its Critics}

Until the late nineteenth century, Anglo-American common law structured marriage to give a husband superiority over his wife in most aspects of the relationship. By law, a husband acquired rights to his wife's person, the value of her paid and unpaid labor, and most property she brought into the marriage. A wife was obliged to obey and serve her husband, and the husband was subject to a reciprocal duty to support his wife and represent her within the legal system. According to the doctrine of marital unity, ${ }^{16}$ a wife's legal identity "merged" into her husband's, so that she was unable to file suit without his participation, whether to enforce contracts or to seek damages in

14. 46 Ala. 143, 146-47 (1871) (emphasis added).

15. See Frances Power Cobbe, Wife-Torture in England, 32 CoNTEMP. REV. 55, 56-57 (1878) ("[Wifebeating] seems to be surrounded by a certain halo of jocosity which inclines people to smile whenever they hear of a case of it (terminating anywhere short of actual murder), and causes the mention of the subject to conduce rather than otherwise to the hilarity of a dinner party. The occult fun thus connected with wifebeating forms by no means indeed the least curious part of the subject.").

16. 1 William BLACKSTONE, COMMENTARIES *442 ("By marriage, the husband and wife are one person in law: that is, the very being or legal existence of the woman is suspended during the marriage, or at least is incorporated and consolidated into that of the husband: under whose wing, protection, and cover, she performs everything ...." (citations omitted)). For a more skeptical account of marital unity doctrine, see TAPPING REEVE, THE LAW OF BARON AND FEMME; OF PARENT AND CHILD; OF GUARDIAN AND WARD; OF MASTER AND SERVANT; AND OF THE POWERS OF COURTS OF CHANCERY 129-30 (NeW Haven, Oliver Steele 1816). 
tort. The husband was in turn responsible for his wife's conduct-liable, under certain circumstances, for her contracts, torts, and even some crimes. ${ }^{17}$

As master of the household, a husband could command his wife's obedience, and subject her to corporal punishment or "chastisement" if she defied his authority. In his treatise on the English common law, Blackstone explained that a husband could "give his wife moderate correction,"

[f]or, as he is to answer for her misbehavior, the law thought it reasonable to intrust him with this power of restraining her, by domestic chastisement, in the same moderation that a man is allowed to correct his apprentices or children; for whom the master or parent is also liable in some cases to answer. But this power of correction was confined within reasonable bounds, and the husband was prohibited from using any violence to his wife, aliter quam ad virum, ex causa regiminis et castigationis uxoris suae, licite et rationabiliter pertinet. ${ }^{18}$

As Blackstone suggested, the master of the household might chastise his wife (or children or servants), but the prerogative was a limited one. A husband was not allowed to do violence to his wife, except as a means of "ruling and chastising" her. The authority Blackstone quoted in support of this principle was the writ of supplicavit-a writ that allowed a wife to petition for court protection when her husband was threatening her with bodily harm. By the terms of the writ, a wife could ask the court to require her husband to provide a guarantee or security bond "that he will not do, or cause to be done, any harm or evil to her body, other than licitly and reasonably pertains to a husband for ruling and chastising his wife."19

17. See 1 William BLACKSTONE, COMMENTARIES *430-33 (citations omitted); 2 JAMES KENT, COMMENTARIES ON AMERICAN LAW 109 (New York, O. Halstead 1827) ("The general rule is, that the husband becomes entitled, upon the marriage, to all the goods and chattels of the wife, and to the rents and profits of her lands, and he becomes liable to pay her debts, and perform her contracts."). See generally NORMA BASCH, IN THE EYES OF THE LAW: WOMEN, MARRIAGE, AND PROPERTY IN NINETEENTH-CENTURY NEW YORK 51-54 (1982) (summarizing analysis of Blackstone's Commentaries); MARYLYNN SALMON, WOMEN AND THE LAW OF PROPERTY IN EARLY AMERICA 15-18, $41-44$ (1986) (discussing doctrine of marital unity as it applied to conveyances and contracts).

18. I WILLIAM BLACKSTONE, COMMENTARIES *444 (citations omitted). Blackstone quoted the Latin pleading of the writ of supplicavit. See Henry Ansgar Kelly, Rule of Thumb and the Folklaw of the Husband's Stick, 44 J. LEGAL EDUC. 341, 353 (1994).

19. Kelly, supra note 18, at 351 (citation omitted) (discussing Fitzherbert's account of writ of supplicavit). Kelly notes:

Here it is stated that "if the husband threaten his wife to beat or to kill her, she shall have this writ," which begins, "Supplicavit nobis A, uxor B, quod cum ipsa de vita sua et mutilatione membrorum suonum per praedictum B graviter et manifeste comminata existat" (A, the wife of $B$, supplicated us that, since she is under grave and manifest threat of her life and the mutilation of her limbs because of the aforesaid B), and so on. Under terms of the writ, the husband is to be summoned and required to guarantee "quod ipse praefatam $A$ bene et honeste tractabit et gubemabit; et dampnum et malum aliquod eidem de corpore suo, aliter quam ad virum suum ex causa regiminis et castigationis uxoris suae licite et rationabiliter pertinent, non faciet, nec fieri procurabit" (that he will not do, or cause to be done, any harm or evil to her body, other than licitly and reasonably pertains to a husband for ruling and chastising his wife). 
Writing in the late eighteenth century, Blackstone asserted that a husband had a right to chastise his wife. Yet he also took pains to qualify the prerogative, describing it as an antiquated practice that persisted primarily among the British lower classes:

\begin{abstract}
But, with us, in the politer reign of Charles the Second, this power of correction began to be doubted; and a wife may now have security of the peace against her husband; or, in return, a husband against his wife. Yet the lower rank of people, who were always fond of the old common law, still claim and exert their ancient privilege: and the courts of law will still permit a husband to restrain a wife of her liberty, in case of any gross misbehaviour. ${ }^{20}$
\end{abstract}

Blackstone's Commentaries played an important role in shaping American legal culture; $;^{21}$ and the law treatises that began to appear in the United States during the early nineteenth century displayed a similar ambivalence about the chastisement prerogative. For example, Kent's Commentaries and Wharton's treatise on criminal law recognized the prerogative in qualified terms, ${ }^{22}$ while America's first family law treatise-authored by Tapping Reeve in 1816-voiced strong doubts about its continuing authority in the United States. Beginning his discussion with the warning that it was "difficult to ascertain, with exactness, what power the husband has over the person of his wife," Reeve proceeded to paraphrase Blackstone's account, interjecting the observation that "[i]n Connecticut, it is not to be denied, that there are to be found brutal husbands who abuse their wives; but the right of chastising a wife is not claimed by any man; neither is any such right recognized by our law."23 In general, it seems that the practice of wife beating was more

Id. at 353; see also LAWRENCE STONE, ROAD TO DIVORCE: ENGLAND, 1530-1987, at 201 (1990) (discussing writ of supplicavit as one form of recourse available to battered wives in seventeenth century).

20. 1 WILliaM BLACKSTONE, COMMENTARIES *445 (citations omitted).

21. See BASCH, supra note 17, at 43-54 (discussing Blackstone's significance in American marital status law); see also DANIEL J. BOORSTIN, THE MYSTERIOUS SCIENCE OF THE LAW: AN ESSAY ON BLACKSTONE'S COMMENTARIES 3-8 (1941); LAWRENCE M. FRIEDMAN, A HISTORY OF AMERICAN LAW 112 (2d ed. 1985) ("Ordinary lawyers referred to Blackstone constantly; they used his book as a shortcut to the law . . . ."); cf. Dennis R. Nolan, Sir William Blackstone and the New American Republic, 51 N.Y.U. L. REv. 731, 732 (1976) (analyzing Blackstone's "oblique" and "diffuse" influence in America).

22. See 2 KENT, supra note 17 , at 180 ("[A]s the husband is the guardian of the wife, and bound to protect and maintain her, the law has given him a reasonable superiority and control over her person, and he may even put gentle restraints upon her liberty, if her conduct be such as to require it."); FRANCIS Wharton, A TREATISE ON THE CRIMINAL LAW OF THE UNITED STATES 314-15 (Philadelphia, James Kay, Jr. \& Brother 1846) (observing that "[b]y the ancient common law, the husband possessed the power of chastising his wife, though the tendency of criminal courts in the present day is to regard the marital relation as no defence to a battery," and discussing Mississippi case allowing exercise of prerogative). See generally 1 JOEL, PRENTISS BISHOP, COMMENTARIES ON THE CRIMINAL LAW 520-26 (Boston, Little, Brown \& Co. 1872) (discussing chastisement prerogative in various status relations of household: parent and child, guardian and ward, teacher and pupil, master and servant, and husband and wife).

23. REEVE, supra note 16 , at 65 . 
frequently addressed in popular culture ${ }^{24}$ than in the published judicial decisions of the antebellum era. Yet cases in a number of states, particularly in the southern and mid-Atlantic regions, recognized a husband's prerogative to chastise his wife. ${ }^{25}$

There were, however, a variety of social forces in antebellum America that combined to draw the legitimacy of the chastisement prerogative into question. Perhaps most prominently, corporal punishment was the subject of widespread social controversy in this period, with campaigns against the practice developing in a variety of contexts. ${ }^{26}$ Reformers questioned the propriety of

24. For a social history of wife beating gleaned from a variety of cultural sources, see Jerome Nadelhaft, Wife Torture: A Known Phenomenon in Nineteenth-Century America, 10 J. AM. CULTURE 39, 42 (1987):

Throughout the nineteenth century wife abuse appeared in poems, songs, and jokes, in temperance stories and novels which blanketed the country, in almanacs, in children's books, in illustrations, and even in at least one card game. Wife abuse was a constant topic in woman's rights conventions and in the literature of the movement ....

25. For American cases recognizing the right of chastisement during the nineteenth century, see Bradley v. State, 1 Miss. (I Walker) 156, 158 (1824) (permitting husband "to exercise the right of moderate chastisement, in cases of great emergency, and use salutary restraints in every case of misbehaviour, without being subjected to vexatious prosecutions, resulting in the mutual discredit and shame of all parties concerned"); State v. Black, 60 N.C. (Win.) 262, 262 (1864) (permitting husband "to use towards his wife such a degree of force as is necessary to control an unnly temper and make her behave herself; and unless some permanent injury be inflicted to gratify his own bad passions, the law will not invade the domestic forum or go behind the curtain"). Cf. Robbins v. State, 20 Ala. 36, 39 (1852) (wife's provocation can be shown in mitigation of husband's fine for assault; "if the husband was at the time... provoked to this unmanly act by the bad behaviour and misconduct of his wife, he should not be visited with the same punishment as if he had without provocation wantonly and brutally injured one whom it was his duty to nourish and protect"); State v. Buckley, 2 Del. (2 Harr.) 552, 552 (1838) (husband indicted for striking his pregnant wife, over his objection that he had right to chastise her; "We know of no law that will authorize a husband to strike his pregnant wife a blow with his fist, such as has been inflicted on this woman .... . [A]ny undue or excessive battery by a husband of his wife either in degree, or with improper means, [is] indictable." (emphasis added)); People v. Winters, 2 Parker's Crim. Cas. 10 (N.Y. 1823) (declaring that while husband has no right to inflict corporal punishment on his wife, he may defend himself against her; holding that husband who struck his wife on head and bruised her severely when she attempted to prevent him from striking one of their children was not guilty of assault and battery because jury found prisoner "had done nothing more than was necessary to defend himself in this case"); State v. Hussey, 44 N.C. (Busb.) 123 (1852) (ruling wife's testimony against her husband incompetent in all cases of assault and battery, except where permanent injury or great bodily harm is either threatened or inflicted); Richards $v$. Richards, 1 Grant's Cas. 389, 392-93 (Pa. 1856) (denying petition for divorce; suggesting that "it is a sickly sensibility which holds that a man may not lay hands on his wife, even rudely if necessary, to prevent the commission of some unlawful or criminal purpose" and further that "some allowance should be made for the frailties of human nature" that "betray[]" a man "into the commission of an act, or a harsh expression, for which, in a moment after, he might be repentant and sorrowful").

Early American cases discussing the writ of supplicavit, whose ancient language recognizes and circumscribes a husband's right to chastise his wife, see supra text accompanying note 19, include: Helms v. Franciscus, 2 Bland 544, 562 n.l (Md. Ch. 1840) (quoting Bread's Case, decided in 1681, in which court granted petition for writ of supplicavit; where wife was threatened with death and mutilation by her husband, court ordered husband to give security under penalty to treat his wife well, and enjoined him from doing "any damage or evil to the said Jane of her body, otherwise than what to a husband, by cause of government and chastisement of his own wife, lawfully and reasonably belongeth"); Adams v. Adams, 100 Mass. 365, 369-70 (1868) (declining to issue writ as substitute for divorce for petitioner who sought alimony but was religiously precluded from obtaining divorce); Codd v. Codd, 2 Johns. Ch. 141 (N.Y. Ch. 1816) (holding that writ is unavailable where injuries occurred eight years before petition); Prather $v$. Prather, 4 S.C. Eq. (4 Des.) 33 (1809) (granting petition for writ).

26. See myra C. Glenn, Campaigns against Corporal Punishment: Prisoners, Sallors, WOMEN, AND CHILDREN IN ANTEBELLUM AMERICA (1984). 
corporal punishment inflicted on prisoners and sailors; ${ }^{27}$ the literature of the abolitionist movement graphically depicted slave whippings in order to dramatize the cruelty of slaveholding; ${ }^{28}$ and experts on family life challenged the traditional use of corporal punishment in the rearing and education of children. A large and growing body of prescriptive literature now argued that parents and teachers should eschew corporal punishment in favor of more gentle methods of discipline. ${ }^{29}$ Force, these experts argued, was an inefficacious method of instilling authority; instead, they advocated "relocati[ng] authority relations in the realm of emotion, and a conscious intensification of the emotional bond between the authority-figure and its charge"-a strategem Richard Brodhead has dubbed "discipline through love." 30 This effort to inculcate authority through introjection of affective relations occurred as the family itself was undergoing a fundamental shift in social structure. With a growing number of men working outside the household, norms and practices of parenting began to focus on the relationship between mother and child rather than father and child. As idealized in the prescriptive literature of the middle class, the family emerged as a site of specialized domestic activities, presided over by a mother figure who dispensed affection and spiritual nurturance to husband and children alike. ${ }^{31}$

As we will see, these changes in conceptions of authority and in family structure were in tension with the social norms of the common law and, over the course of the nineteenth century, would contribute to the reform of the chastisement prerogative, as well as many other marital status rules of the common law. ${ }^{32}$ Yet, for all the public discussion of corporal punishment, talk

27. See, e.g., id. at 12-13, 85-147.

28. See, e.g., RichaRd H. BRODHEAD, CULTURES OF LeTtERs: ScENES OF READING AND WRITING in NineteENTH-CENTURY AMERICA 13-15 (1993); $c f$. KAREN SÁNCHEZ-EPPLER, TOUCHING LIBERTY: ABOLITION, FEMINISM, AND THE POLITICS OF THE BODY (1993) (analyzing antislavery discourse).

29. See BRODHEAD, supra note 28 , at $18-27$.

30. Id. at 18-19. The brilliant analysis of "disciplinary intimacy" that Brodhead offers in Cultures of Letters has also been published separately. See Richard H. Brodhead, Sparing the Rod: Discipline and Fiction in Antebellum America, 21 REPRESENTATIONS 67 (1988). For a similar account of this shift in social conceptions of discipline, see G.M. GOSHGARIAN, TO KISS THE CHASTENING ROD: DOMESTIC FICTION AND SEXUAL IDEOLOGY IN THE AMERICAN RENAISSANCE 39-40 (1992).

31. See, e.g., NANCY F. COTT, THE BONDS OF WOMANHOOD: "WOMAN's SPHERE" IN NEW ENGLAND, 1780-1835 (1977); MARY P. RYAN, THE EMPIRE OF THE MOTHER: AMERICAN WRITING ABOUT DOMESTICITY 1830-1860 (1982); BARBARA WELTER, DIMITY CONVICTIONS: THE AMERICAN WOMAN IN THE NINETEENTH CENTURY (1976).

32. For a discussion of the shifting understandings of the marriage relationship that contributed to reform of marital chastisement doctrine, see especially infra Part II.

The relationship between changing social mores and law reform is obviously a complex one, explored in Part IV of this Article. For now, it suffices to observe that, during the nineteenth century, reformers sought to persuade parents and teachers to abandon corporal punishment of children and organized the first societies for the prevention of cruelty to children, but did not seek reform of the parent's legal prerogative to chastise a child. By contrast, discussion of wife beating during the antebellum era was relatively circumspect, see infra note 33, yet resulted in repudiation of the marital chastisement prerogative. 
about wife beating during the antebellum era, and after, remained circumspect. $^{33}$

The first organized protest against wife beating did not challenge the husband's legal prerogative to inflict marital chastisement; it approached marital violence without even directly questioning the husband's authority over his wife. It was the antebellum temperance movement that first initiated public conversation about wife beating. As temperance advocates demonstrated the social evils of alcohol, they drew attention to the violence that drunken husbands so often inflicted on their families. ${ }^{34}$ The movement's conventions, newspapers, poems, songs, and novels featured vivid accounts of women and children who had been impoverished, terrorized, maimed, and killed by drunken men. ${ }^{35}$ Temperance protest was simultaneously radical and conservative in tenor. Condemning alcohol provided reformers an outlet for criticizing the social conditions of family life, in the name of protecting the sanctity of family life. Initially, at least, temperance activists preached one remedy for the family violence they so graphically depicted: prohibiting the sale of alcohol.

Soon thereafter, a very different kind of challenge to wife beating was mounted by the woman's rights movement that grew out of temperance and abolitionist protests of the antebellum era. Although membership in this new reform initiative was relatively small, the group was well connected to social elites both within and outside government. ${ }^{36}$ In 1848 , when the woman's

33. See GLENN, supra note 26, at 80-82. Myra Glenn's history of corporal punishment observes that "[i]n comparison with reform efforts on behalf of chastised seamen, convicts, slaves, and children, there was relatively little public criticism of wife beating during the antebellum period. Idealized views of marriage and women imposed a crucial ideological barrier to widespread public discussion of wife beating." Id. at 80. Even after the repudiation of marital chastisement, public discussion of wife beating remained muted. For example, by the 1880 s most urban areas had begun to organize societies for prevention of cruelty to children; yet only one city had a society for prevention of cruelty to wives. See ELIZABETH PleCK, Domestic Tyranny: The Making of American SOCIal Policy Against Family ViolenCE FROM COLONIAL TIMES to THE PRESENT 88 (1987) [hereinafter PLECK, DOMESTIC TYRaNNY]. As Linda Gordon has shown, societies for prevention of cruelty to children served as clearinghouses for problems of marital violence as well. See LINDA GORDON, HEROES OF THEIR OWN LIVES: THE POLITICS AND HISTORY OF FAMILY VIOLENCE 252-64, 280-85, 288, 298 (1988) [hereinafter GORDON, HEROES].

34. See Barbara L. Epstein, The Politics of Domesticity: Women, Evangelism, and TEMPERANCE IN NINETEENTH-CENTURY AMERICA 109-10 (1981); PLECK, DOMESTIC TYRANNY, supra note 33, at 98-101. See generally RUTH BORDIN, WOMAN AND TEMPERANCE: THE QUEST FOR POWER AND LIBERTY, 1873-1900 (1981) (recounting history of Woman's Christian Temperance Union).

35. See Nadelhaft, supra note 24 , at $42-44$.

36. For a general discussion of the nineteenth-century woman's rights movement, see STEVEN M.

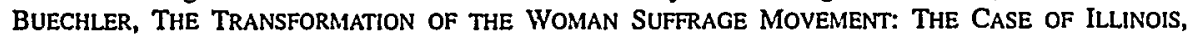
1850-1920 (1986); Ellen Carol DuBois, Feminism and SufFrage: THE EMERGenCE of aN INDEPENDENT WOMEN'S MOVEMENT IN AMERICA, 1848-69 (1978); ELEANOR FLEXNER, CENTURY OF STRUGGLE: THE WOMAN'S RIGHTS MOVEMENT IN THE UNITED STATES (rev. ed. 1975); AILEEN S. KRADITOR, THE IDEAS OF THE WOMAN SUFFRAGE MOVEMENT, 1890-1920 (W.W. Norton \& Co. 1981) (1965). 
rights movement held its first convention, it denounced the common law doctrines of marital status in a formal Declaration of Sentiments:

He has made her, if married, in the eye of the law, civilly dead.

He has taken from her all right in property, even to the wages she earns.

... In the covenant of marriage, she is compelled to promise obedience to her husband, he becoming, to all intents and purposes, her master-the law giving him power to deprive her of her liberty, and to administer chastisement. ${ }^{37}$

During the 1850s, woman's rights advocates organized numerous conventions throughout the Northeast and Midwest, published newspapers, and conducted petition campaigns seeking for women the right to vote and demanding various reforms of marriage law. And in time the movement did elicit a response. Legislatures and courts began to modify the common law of marital status-first giving wives the right to hold property in marriage, and then the right to their earnings and the rudiments of legal agency: the right to file suit in their own names and to claim contract and tort damages. ${ }^{38}$

The woman's rights movement differed from the temperance movement, both in its diagnosis of family violence and in the social remedies it proposed. As the Declaration of Sentiments illustrates, the chastisement prerogative figured prominently in the feminist movement's first challenge to the marital status rules of the common law. Woman's rights advocates protested the hierarchical structure of marriage; and, as they did so, they attacked the chastisement prerogative as a practical and symbolic embodiment of the husband's authority over his wife. The woman's rights movement thus broke with the temperance movement by depicting wife beating as a symptom of fundamental defects in the legal structure of marriage itself. The movement's 1848 Declaration of Sentiments identified chastisement as part of a political system of male dominance, an analysis that feminists continued to elaborate in the ensuing decades. ${ }^{39}$

For woman's rights advocates, a structural diagnosis of male violence against women dictated a structural remedy. Beginning in the 1850 s, a vocal minority in the movement argued that wives should be allowed to divorce

37. REPORT OF THE WOMAN'S RightS CONVENTION, HELD AT SENECA FALLS, N.Y., JULY 19TH \& 20TH, 1848, at 6 (Rochester, John Dick 1848) [hereinafter SENECA FALLS CONVENTION REPORT] (emphasis added).

38. For an illustration of the slow progress of common law reform, see Reva B. Siegel, The Modernization of Marital Status Law: Adjudicating Wives' Rights to Earnings, 1860-1930, 82 GEO. L.J. 2127, 2149-57 (1994) [hereinafter Siegel, Modernization] (describing interaction of legislature and courts in New York state in late nineteenth century); see also Reva B. Siegel, Home As Work: The First Woman's Rights Claims Concerning Wives' Household Labor, 1850-1880, 103 YALE L.J. 1073, 1167-77 (1994) [hereinafter Siegel, Home As Work] (describing legislative responses to feminist demands for suffrage, inheritance reforms, and rights to earnings during 1870s).

39. See SENECA FALlS CONVENTION REPORT, supra note 37, at 5-7. 
drunken, violent husbands. ${ }^{40}$ But if most woman's rights advocates were not ready to embrace the politically explosive demand for divorce, all were united in the view that state-sanctioned violence in the marriage relationship evidenced fundamental defects in its structure and proved the justice of women's demand to participate in the enactment and enforcement of the laws. They pointed to the chastisement prerogative and to gruesome reports of wife beating in the tabloid press as proof that women needed the vote and did not in fact receive "virtual representation" through male suffrage. ${ }^{41}$ As one of the movement's newspapers argued in the 1870s, domestic violence exposed the "fiction of Woman's protection by man" and thus demonstrated "the necessity that women should have increased power, social, civil, legal, political and ecclesiastical, in order to protect themselves."42 "These horrors," another writer contended, "result inevitably from the subjection and disfranchisement of women, just as similar outrages used to result from the subjection and disfranchisement of negroes. Equal Rights and Impartial Suffrage are the only radical cure for these barbarities."

\section{B. Formal Repudiation of the Right of Chastisement}

Over time, the American legal system did respond to these criticisms of wife beating. Decades of protest by temperance and woman's rights advocates, combined with shifting attitudes toward corporal punishment and changing gender mores, together worked to discredit the law of marital chastisement. By the 1870s, there was no judge or treatise writer in the United States who recognized a husband's prerogative to chastise his wife. Thus, when a wife beater was charged with assault and battery, judges refused to entertain his claim that a husband had a legal right to strike his wife; instead they

40. See PLECK, DOMESTIC TYRANNY, supra note 33, at 57-62. For examples of how the divorce question was addressed in early feminist debates, see PROCEEDINGS OF THE TENTH NATIONAL WOMAN'S Rights CONVENTION, Held AT THE COOPER INSTITUTE, NEW YORK CITY, MAY 10TH AND 11TH, 1860, at 88-90, 95-97 (Boston, Yerrinton \& Garrison 1860). See also 1 HISTORY OF WOMAN SuFFRAGE 723-37 (Ayar Co. 1985) (Elizabeth C. Stanton et al. eds., New York, Fowler \& Wells 1881). For an example of how marital violence figured in Elizabeth Stanton's arguments for divorce, see infra text accompanying note 117.

41. See DuBols, supra note 36 , at $46-47$; KRADITOR, supra note 36 , at $112,121$.

42. Crimes Against Women, Woman's J., Dec. 25, 1875, at 413, 413 (column signed C.C.H. of East Orange, New Jersey).

43. Crimes of a Single Day, Woman's J., Jan. 29, 1876, at 34, 34 (column signed H.B.B.). 
denounced the prerogative, and allowed the criminal prosecution to proceed. ${ }^{44}$ In several states, legislatures enacted statutes specifically prohibiting wife beating; three states even revived corporal punishment for the crime, providing that wife beaters could be sentenced to the whipping post. ${ }^{45}$

But it would be misleading to look to the repudiation of chastisement doctrine as an indicator of how the legal system responded to marital violence. As we will see, during the Reconstruction Era, jurists and lawmakers vehemently condemned chastisement doctrine, yet routinely condoned violence in marriage. And when the legal system did prosecute wife beating, it treated the crime as a deviant social act rather than as conduct recently condoned by law, selecting men for prosecution in ways that suggest that concerns other than protecting women animated the punishment of wife beaters.

In short, while we can say that the American legal system repudiated the doctrine of marital chastisement by the end of the Civil War, the significance of this doctrinal development is far from self-evident. To illustrate the complex attitudes toward marital violence underlying formal repudiation of the prerogative, this section examines two opinions written in 1871 that repudiate the husband's prerogative to chastise his wife, one from Massachusetts and the other from Alabama. ${ }^{46}$ It situates these opinions in a broader sociolegal context in order to suggest some of the gender-, class-, and race-based judgments shaping the regulation of marital violence in the wake of chastisement's demise.

\section{Relief for Battered Wives: Separation and Divorce}

We can begin by considering the repudiation of marital chastisement in Massachusetts, a relatively liberal jurisdiction where the woman's movement was well connected to social elites. The Massachusetts Supreme Court rejected a husband's prerogative to chastise his wife in the 1871 case of

44. See, e.g., Fulgham v. State, 46 Ala. 143, 147 (1871); Richardson v. Lawhon, 4 Ky. L. Rptr. 998 , 999 (1883) (abstract) (action for unlawful arrest) ("The husband has no right to inflict personal chastisement upon his wife. She is entitled to the same protection from violence at the hands of her husband that a stranger is entitled to."); Commonwealth v. McAfee, 108 Mass. 458, 461 (1871) (husband indicted for manslaughter after beating his wife and causing her death) ("Beating or striking a wife violently with the open hand is not one of the rights conferred on a husband by the marriage, even if the wife be drunk or insolent."); Harris v. State, 14 So. 266 (Miss. 1894) ("[T]he blind adherence shown in [a prior Mississippi chastisement case] to revolting precedent has long been utterly repudiated."); Gorman v. State, 42 Tex. 221, 223 (1875).

45. Elizabeth Pleck, The Whipping Post for Wife Beaters, 1876-1906, in EsSAYS ON THE FAMILY AND Historical Change 127 (David Levine et al. eds., 1983) [hereinafter Pleck, The Whipping Post]; see infra text accompanying note 75 .

46. In selecting these cases for discussion, I suggest some regional factors that may have shaped the repudiation of chastisement (e.g., woman's rights activism, disestablishment of slavery) without drawing definitive conclusions about the role regional factors played in the regulation of marital violence. At present, the sources available are too scant to support this kind of analysis. Treatise discussions of the period refer to a relatively small body of appellate opinions, see supra notes 25,44 , and records of local law enforcement authorities are also sparse, see infra note 50 (discussing archival problems). 
Commonwealth v. McAfee ${ }^{47}$ The husband in this case struck his inebriated wife several times on the cheek and temple; she fell, struck her head, and died. When prosecuted for manslaughter, the defendant requested the judge to instruct the jury "that the husband had a legal right to administer due and proper correction and corporeal [sic] chastisement on his wife";; $;$ but the trial judge refused. The Massachusetts Supreme Court affirmed, announcing that "[b]eating or striking a wife violently with the open hand is not one of the rights conferred on a husband by the marriage, even if the wife be drunk or insolent."

Of course, the facts of the McAfee case provided the court with a congenial context in which to repudiate the right of chastisement. At no point had the right of "moderate correction" justified manslaughter; both before and after the demise of chastisement, the legal system prosecuted cases of aggravated assault resulting in the death of a wife or her severe injury. ${ }^{50}$ In other circumstances, however, Massachusetts was considerably less responsive to the plight of battered wives. Massachusetts was a stronghold of woman's rights advocacy, yet the movement was unsuccessful in persuading authorities to adopt reform legislation protecting battered wives from abusing husbands. For example, after publicizing various "crimes against women" in the Woman's

47. 108 Mass. 458 (1871).

48. Id. at 459 .

49. Id. at 461 .

50. For common law restrictions on the right of "moderate correction," see supra text accompanying notes 18-20 (discussing writ of supplicavit as restraint on chastisement). See also Kelly, supra note 18, at 353 (discussing old English law governing manslaughter charges in circumstances in which "'a man corrects his wife, his servant, or child, or his pupil reasonably, without intending to kill her or him, and he or she dies of it"'). For a discussion of customary restraints on marital chastisement, see Russell P. Dobash \& R. Emerson Dobash, Community Response to Violence Against Wives: Charivari, Abstract Justice and Patriarchy, 28 SOC. PROBS. 563 (1981).

For criminal cases decided after the repudiation of chastisement that involve severe cases of spousal assault, see, e.g., Carpenter v. Commonwealth, $92 \mathrm{Ky} .452,453$ (1892) (husband convicted of maliciously and unlawfully cutting his wife's throat, with intent to take her life); State v. Mabrey, 64 N.C. 592, 593 (1870) (husband guilty of assault where he wielded knife and threatened to kill his wife, until deterred by bystander; "the courts will not invade the domestic forum, to take cognizance of trifling cases of violence in family government; but there is no relation which can shield a party who is guilty of malicious outrage or dangerous violence committed or threatened.").

Because published opinions in such cases are scarce and much primary research remains to be done on the operations of the police courts that handled cases of marital violence among the poor, it is difficult to gauge the types of injury that elicited regular police response. See Elizabeth Pleck, Criminal Approaches to Family Violence, 1640 1980, in II FAMILY VIOLENCE 19,30 (Michael Tonry \& Norval Morris eds., 1989) [hereinafter Pleck, Criminal Approaches]. Elizabeth Pleck observes that "[t]he operation of police courts up to the 1870's has not been studied, largely because of the lack of available documents," and notes only one study of police courts from 1870 to 1920 (examining the records of the Oakland, California police courts). Id. She concludes that "[w]e do not know whether the conviction rate was lower in cases of family violence than it was in other crimes against the public order," id. at 31, but she surmises that it was, with lower arrest and prosecution rates, see id. For an interesting study of local enforcement activity, see Pamela Haag, The "Ill-Use of a Wife": Patterns of Working-Class Violence in Domestic and Public New York City, J860-1880, 25 J. SoC. HiST. 447 (1992) (examining dockets of Court of General Sessions for New York City, which heard cases that city police courts recommended for trial). 
Journal during the $1870 \mathrm{~s}^{51}$ Lucy Stone led the editors of this Boston-based suffrage paper in a petition campaign to persuade the Massachusetts legislature to adopt a bill-modeled after recent legislation in England-that would have given battered wives protection from their husbands. ${ }^{52}$ The proposed bill provided that when a husband was convicted of aggravated assault, his wife could apply to the court for an order "forbidding her husband to visit her without her permission, and giving her the custody of her minor children, and directing the officer of the court or the overseers of the poor to collect from the husband and pay to her a reasonable weekly allowance for support of the family."53 The Massachusetts legislature rejected the petition, on the grounds that such legislation "would be granting to police and district courts the power of decreeing divorce." 54 Instead, in 1879, the legislature adopted a law allowing courts to order a husband convicted of assaulting his wife to keep the peace, under a bond with penalties that the judge might waive at his discretion; the peace bond might be imposed in addition to, or in lieu of, other penalties for assault. ${ }^{55}$

In rejecting the reform legislation advocated by the woman's movement and adopting this obviously ineffectual restraint on domestic violence, the Massachusetts legislature made explicit its hostility to remedies for domestic violence that might assist wives in separating from their husbands. In this era, Massachusetts did allow some wives to obtain a divorce on grounds of cruelty. Battered wives had to prove acts of violence amounting to "extreme cruelty," a standard that the state's courts construed quite restrictively. As the Massachusetts Supreme Judicial Court explained in 1867, "there may be personal violence which does not amount to what is regarded as cruelty; and ... there may be cruelty without personal violence."56 The court suggested that the class background of the woman petitioning for divorce was relevant to evaluating the merits of her cruelty claim: "Among the lower classes, blows sometimes pass between married couples who in the main are happy, and have no desire to part. Amidst very coarse habits . . . a word and a blow go together.",57

51. See Elizabeth Pleck, Feminist Responses to "Crimes Against Women," 1868-1896, 8 SiGNS 451, 458-59 (1983) [hereinafter Pleck, "Crimes Against Women"].

52. See Lucy Stone, Cruelty to Wives, Woman's J., Jan. 11, 1879, at 12, 12; Legal Relief For Assaulted Wives, WoMAN's J., Jan. 11, 1879, at 12, 12.

53. Henry B. Blackwell, Legal Redress for Assaulted Wives, WomaN's J., Jan. 18, 1879, at 20, 20.

54. Id. (quoting report of House Committee on the Judiciary).

55. An Act for the Protection of Married Women, 1879 Mass. Acts 444.

56. Bailey v. Bailey, 97 Mass. 373, 380 (1867).

57. Id. at 379 (quoting Shelford's treatise on marriage and divorce) (asserting that "“[a] blow between parties in the lower conditions and in the higher stations of life bears a very different aspect" and affirming jury decision denying divorce petition of woman who alleged her husband shut her arm in a door and bit her arm, deprived his wife and children of furniture and food for close to a month, and after they reconciled again beat her); see also Ford v. Ford, 104 Mass. 198, 205-06 (1870) (upholding jury verdict that husband's violence on one occasion does not meet standard of "extreme cruelty"; excluding evidence of other assaultive conduct). 
In the decades after the Civil War, legislatures were expanding the statutory grounds for divorce, and judges charged with applying these statutory norms interpreted them ever more liberally. In most jurisdictions, a wider range of somatic harms now supplied evidence of "cruelty" as a grounds for divorce, ${ }^{58}$ but, as Massachusetts law illustrates, courts gave sense to the concept in ways that drew upon gender- and class-based understandings of the marriage relationship. To demonstrate that she was entitled to a divorce, a battered wife typically had to prove that her husband acted with "extreme" and "repeated" cruelty. ${ }^{59} \mathrm{~A}$ husband in turn could defeat his wife's divorce petition either by showing that she misbehaved in some way that "provoked" his violence, or by showing that she delayed petitioning for divorce and so forgave and "condoned" his violence. ${ }^{60}$ In other words, nineteenth-century

Massachusetts divorce law was not atypical in its attention to the class status of the petitioners. See Goodrich v. Goodrich, 44 Ala. 670, 682 (1870) (that husband provided his wife expensive clothing does not mitigate the fact he battered her; "to a refined and educated woman, accustomed to be caressed and admired, as ladies in her station in society usually are, what are baubles such as these in comparison to the love and sympathy of her husband?").

58. See GLENN, supra note 26, at 68-70; Robert L. Griswold, The Evolution of the Doctrine of Mental Cruelty in Viciorian American Divorce, 1790-1900, 19 J. SoC. HIST. 127, 132-35 (1986) [hereinafter Griswold, Mental Cruelty]; Robert L. Griswold, Law, Sex, Cruelty, and Divorce in Victorian America, J840-1900, 38 AM. Q. 721, 723 (1986) [hereinafter Griswold, Divorce in Victorian America]; Robert L. Griswold, Sexual Cruelty and the Case for Divorce in Victorian America, 11 SiGNS 529, 529-32 (1986) [hereinafter Griswold, Sexual Cruelty].

For statistics on the divorce rate in this era, as well as the frequency with which divorce was granted on grounds of cruelty, see GLENN, supra note 26, at 65; Griswold, Divorce in Victorian America, supra, at 722:

By today's standards, the figures on divorce in the late nineteenth and early twentieth centuries are quite low, but they seemed alarmingly high to contemporaries. From 1867 to 1886 , United States courts granted 328,716 divorces; in the next twenty years, the number jumped to 945,625 , far outstripping the proportionate rise in population.

At the center of this increase was a giant rise in the number of cases brought on the grounds of cruelty. From 1867 to 1906, wives received 218,520 divorces because of cruelty and husbands 39,300 . Next to nonsupport, cruelty cases rose more sharply than cases based on any other cause in these years. Comparing the years 1902-1906 with 1867-1871, divorces granted to wives on the ground of cruelty jumped 960 percent, and to husbands 1,610 percent. Between 1867 and 1871,18 percent of divorces granted to wives were on the ground of cruelty; that figure for the years 1902-1906 was 29 percent. The same comparison for husbands reveals a jump from 4 percent to 12.5 percent.

59. See, e.g., 2 CHESTER G. Vernier, AMERICAN FAMILY LAWs $\S 66$ (1932) (quoting, by state, statutory definitions of cruelty as ground for divorce); see also State v. Rhodes, 61 N.C. (Phil. Law) 453 , 455 (1868):

Our divorce laws do not compel a separation of husband and wife, unless the conduct of the husband be so cruel as to render the wife's condition intolerable .... In some cases it has been held that actual and repeated violence to the person, was not sufficient. In others that insults, indignities and neglect without any actual violence, were quite sufficient.

60. On the defense of provocation, see, e.g., Knight v. Knight, 31 Iowa 451, 458 (1871):

"If what is complained of as cruelty is the result of the complainant's own misconduct, it will not furnish ground for the proceeding. The remedy is in her own power; she has only to change her conduct; otherwise the wife would have nothing to do but misconduct herself, provoke the ill treatment and then complain."

Id. at 458 (quoting Bishop's treatise on marriage and divorce). See generally Annotation, Conduct Amounting to Treatment Endangering Life Within Statute Defining Grounds for Divorce, 5 A.L.R. 712, 719-22 (1920) (discussing defense of provocation).

On the defense of condonation, see, e.g., Davies v. Davies, 37 N.Y. 45, 46, 48 (1869) (where husband "choked [wife]; committed severe personal violence upon her, and struck her a blow with his fist upon the 
judges developed a body of divorce law premised on the assumption that a wife was obliged to endure various kinds of violence as a normal一and sometimes deserved-part of married life. Furthermore, as Massachusetts law illustrates, judges reasoned about the propriety of violence in the marriage relationship with attention to the economic status of the married couple, with the result that the evidence required to prove "extreme cruelty" varied by class, on the doctrinally explicit assumption that violence was a common part of life among the married poor. ${ }^{6 t}$

The class-based assumptions about marital violence that shaped divorce law in this era also shaped the criminal law, but with very different regulatory consequences. While courts pointed to the prevalence of domestic violence among the "coarser" classes as a reason for restricting poor women's access to divorce, during the Reconstruction Era this same belief was offered as a reason for intensifying the criminal prosecution of poor men who beat their wives.

\section{Race and Class Bias in the Criminal Prosecution of Wife Beaters}

In 1871, the year that the Massachusetts Supreme Judicial Court handed down the McAfee opinion, Alabama also repudiated the right of chastisement in the case of Fulgham v. State. ${ }^{62}$ In Fulgham, an emancipated slave chastising one of his children was interrupted by his wife (also an emancipated slave), who thought the punishment inflicted on the child excessive; the husband then struck his wife twice on the back with a board. The husband was indicted on charges of assault and battery. On appeal, the Alabama Supreme Court allowed the prosecution, expressly repudiating the right of marital chastisement. The court reasoned that Blackstone "confines this brutal and unchristian 'privilege' wholly to the 'lower rank of the people.' ... [However, s]uch partial laws cannot be enforced in this State, [where t] he law for one

left temple, severing the temporal artery, and endangering [her] life" but wife continued to cohabit with husband for about 15 months thereafter, such cohabitation "implies a forgiveness of such treatment" and "court would not grant a divorce for such ill treatment, if in the interval, the defendant had treated his wife kindly and given her no further cause of complaint."). See also Barber v. Barber, 62 U.S. 582, 593-94 (1858) (discussing doctrine of condonation as it bears on domicile of woman seeking divorce). See generally Annotation, Condonation of Cruel Treatment as Defense in Divorce Action, 14 A.L.R. 931 (1921) (discussing defense of condonation).

61. See, e.g., Bailey v. Bailey, 97 Mass. 373, 379 (1867) (quoting Shelford's treatise on marriage and divorce: "A blow between parties in the lower conditions and in the higher stations of life bears a very different aspect.'") (affirming jury decision denying divorce petition of woman who alleged her husband shut her arm in door and bit her arm, deprived her and their children of furniture and food for close to a month, and, after they reconciled, again beat her). See generally Griswold, Mental Cruelty, supra note 58, at 134-35 (discussing class-conscious application of mental cruelty doctrines, illustrated by quotations drawn from numerous contemporary commentators).

62. 46 Ala. 143 (1871). 
rank is the law for all ranks of the people, without regard to station." ${ }^{963}$ The court then asserted that

Judge Blackstone . . . published his commentaries above one hundred years ago, when society was much more rude ... than it is at the present day in this country; and the exercise of a rude privilege there is no excuse for a like privilege here. ... S Since then, however, learning, with its humanizing influences, has made great progress, and morals and religion have made some progress with it. Therefore, a rod which may be drawn through the wedding ring is not now deemed necessary to teach the wife her duty and subjection to the husband. The husband is therefore not justified or allowed by law to use such a weapon, or any other, for her moderate correction. The wife is not to be considered as the husband's slave. And the privilege, ancient though it be, to beat her with a stick, to pull her hair, choke her, spit in her face or kick her about the floor, or to inflict upon her like indignities, is not now acknowledged by our law. ... [I]n person, the wife is entitled to the same protection of the law that the husband can invoke for himself. . . . Her sex does not degrade her below the rank of the highest in the commonwealth. ${ }^{64}$

This powerful statement of sex and class equality creates a refreshing point of contrast with Massachusetts cruelty doctrines; yet it also raises a new set of questions. Simply put: Why was it that Alabama authorities showed such solicitude for the plight of this recently emancipated freedwoman-especially given the prevailing assumption that violence was a common part of life among the married poor? Was it to ensure that the woman was not treated like a "slave," or to prevent her recently emancipated husband from asserting the "privileges" of a master? The question is worth asking, especially of an opinion authored by an ex-slaveholder. ${ }^{65}$ Though the text of the Fulgham opinion addresses gender relations, the case seems to resonate with racial preoccupations.

63. Id. at 146 .

64. Id. at 146-47 (emphasis added) (citations omitted).

65. The appellate opinion in the Fulgham case was written by Associate Justice Thomas M. Peters. Id. at 3, 145. Peters was a slaveowner before and during the war; he later became a prominent Southern Unionist and was active after the war in Alabama's constitutional convention. See MALCOLM C. MCMillan, CONSTItUTIONAL DEVELOPMENT IN ALABAMA, 1798-1901: A STUDY in POLITICS, the NEGRO, AND SECTIONALISM 121 n.57 (1955). McMillan notes:

Peters was a lawyer, graduate of the University of Alabama, an old-line Whig in politics, supporter of Douglas in 1860, and bitter opponent of secession in 1861. Prior to the war he had been state representative and senator. Although he lost more than twenty slaves during the war and was frequently hanged in effigy by his neighbors, his house became the center for Union sentiment in his North Alabama Congressional district. He was a man of much culture, a botanist, could read French and Latin, and during the convention of 1867 was most interested in education and penal reform.

Id. 
In fact, Alabama was not the only Southern state to make an example of an African-American charged with beating his wife. ${ }^{66}$ When the Supreme Court of Mississippi repudiated chastisement doctrine in the case of Harris $v$. State, ${ }^{67}$ the case also involved a black man. On this occasion, the court obliquely addressed the racial concerns animating its decision:

The suggestion in the evidence of a belief among the humbler class of our colored population of a fancied right in the husband to chastise the wife in moderation makes it proper for us to say that this brutality found in the ancient common law, though strangely recognized in Bradley v. State, [1 Miss. (1 Walker) 156 (1824)], has never since received countenance; and it is superfluous to now say that the blind adherence shown in that case to revolting precedent has long been utterly repudiated, in the administration of criminal law in our courts. $^{68}$

Both Fulgham and Harris repudiate chastisement doctrine, but the opinions seem more interested in controlling African-American men than in protecting their wives. ${ }^{69}$

During the Reconstruction Era, public interest in marital violence rose as wife beating began to shift in political complexion from a "woman's" issue to a "law and order" issue. Wife beating now attracted the interest of groups not known for their commitment to temperance or woman's rights causes. During this period, the $\mathrm{Ku} \mathrm{Klux} \mathrm{Klan} \mathrm{took} \mathrm{an} \mathrm{interest} \mathrm{in} \mathrm{punishing} \mathrm{wife} \mathrm{beaters} \mathrm{(both}$ white and black), and began to invoke wife beating as an excuse for assaults on black men. ${ }^{70}$ In 1878 , the transatlantic publication of Frances Cobbe's

66. Before the war, masters forbade slaves to beat their partners, and the Freedmen's Bureau continued to regulate such conduct in the aftermath of the war. See Catherine Clinton, Bloody Terrain: Freedwomen, Sexuality and Violence During Reconstruction, 76 GA. HIST. Q. 313, 319 (1992) ("White observers condemned husbands who considered wifebeating a 'right' and resisted bureau intervention. Ex-slaves reported that before emancipation masters prohibited slave men from striking their wives-and agents revealed that they assumed this paternalistic role after abolition."); see also Sara Rapport, The Freedmen's Bureau as a Legal Agent for Black Men und Women in Georgia: 1865-1868, 73 GA. HisT. Q. 26, 39-41 (1989) (describing efforts of Freedmen's Bureau to prosecute wife beating among emancipated slaves in aftermath of Civil War).

67. 14 So. 266 (Miss. 1894).

68. Id. at 266. For a discussion of the Bradley case to which the opinion refers, see infra notes 129-31 and accompanying text.

69. Cf. Martha Hodes, The Sexualization of Reconstruction Politics: White Women and Black Men in the South after the Civil War, 3 J. HIST. SExuALITY 402, 403 (1993) (analyzing "white anxiety and alarm about black male sexuality" in the Reconstruction South).

70. Klan attacks on black and white men said to have beaten their wives first came to light in 1871 , when Congress embarked upon an extensive investigation of the Klan's activities in the states of the former Confederacy. Although it is difficult to discern at this distance precisely how widespread this practice ultimately became, the testimony of numerous witnesses who appeared before the Joint Select Committee suggests that wife beating often served as a justification for assaults on the freedmen and their supporters. Testifying to the circumstances surrounding the shooting death of an African-American man in rural Mississippi, one witness explained, "[i]t was supposed that he was killed for whipping his wife." 11 U.S. CONGRESS, REPORT OF THE JOINT SELECT COMMITTEE TO INQUIRE INTO THE CONDITION OF AFFAIRS IN THE LATE INSURRECTIONARY STATES 361 (1872) [hereinafter KKK REPORT]. Similarly, an Alabama 
exposé of marital violence, Wife-Torture in England ${ }^{71}$ prompted efforts by woman's rights activists to secure enactment of legislation that would have assisted battered women in separating from their husbands, ${ }^{72}$ but the article's critical discussion of an alternate remedy-flogging wife beaters ${ }^{73}$ apparently sparked more widespread interest. By the 1880s, prominent members of the American Bar Association advocated punishing wife beaters at the whipping post, and campaigned vigorously for legislation authorizing the penalty. ${ }^{74}$ Between 1876 and 1906, twelve states and the District of Columbia considered enacting legislation that provided for the punishment of wife beaters at the whipping post. The bills were enacted in Maryland (1882), Delaware (1901), and Oregon (1906). ${ }^{75}$

With this surge of interest in wife beating, the wife beater was demonized as a deviant character, whose criminal or licentious propensities authorities needed to control in order to secure social stability. Those who sought to revive corporal punishment for wife beating argued that wife beaters were an

witness-when asked to characterize the nature of the "offenses" likely to provoke Klan attacks-immediately recalled the ordeal of a local man who had been "charged with whipping and maltreating his wife." As a result, he explained, "a body of men," all of whom were apparently "in disguise," "went there and took him out and gave him a whipping on his bare back, and admonished him to more proper customs in his domestic habits ..." 8 id. at 611 . Speaking more generally about Klan practices in the state, another witness asserted that "[w]here a man whipped his wife these [Klans]men were apt to deal with it." 9 id. at 987.

White Republicans were also vulnerable to Klan attack where domestic discord was supposed to have been present. In one of the more oblique references to spousal abuse contained in the report, a white man was allegedly subjected to assault because "[h]e and his wife had a little falling out." 13 id. at 48 . For similar cases of Klan violence, see $10 \mathrm{id}$. at 1808; $12 \mathrm{id}$. at 502; and $13 \mathrm{id}$. at 13 . In addition to the public posture they assumed against wife beating, members of white-supremacist organizations such as the Ku Klux Klan leveled a number of more overtly sexual charges, notably incest, abortion, miscegenation, and cohabitation, as warrant for their attacks. Indeed, Reconstruction-era Klansmen were given to inflicting outrages on the bodies of their victims that were themselves highly sexualized-including everything from the whipping, burning, and mutilation of genitals to complete castration.

I am indebted to Lisa Cardyn for this account of Klan involvement in "prosecuting" wife beaters. See Lisa Cardyn, Sexualized Racism and Gendered Violence: Outraging the Body Politic in the ReconstructionEra South (Apr. 9, 1996) (unpublished manuscript, on file with author); see also Hodes, supra note 69 (exploring white Southern preoccupation with black male sexuality during Reconstruction Era); Pleck, The Whipping Post, supra note 45, at 137 ("The campaign to reintroduce the whipping post also coincided with a resurgence of mob violence, of vigilantes in the West, lynch mobs in the South, and White Caps in the Middle West.").

As Bertram Wyatt-Brown has observed, there is some resemblance between the vigilante attacks undertaken by Reconstruction-era white-supremacist groups and the generally more benign activities of the European charivari. BERTRAM WYATT-BROWN, SOUTHERN HONOR: ETHICS AND BEHAVIOR IN THE OLD SOUTH 436-38, 442-47 (1982). On early-modern European mob actions against suspected wife beaters, see, e.g., E.P. ThOMPSON, CUSTOMS IN COMMON 492, 505, 510, 512 (1991); Dobash \& Dobash, supra note 50, at $565-69$.

71. Cobbe, supra note 15.

72. See supra text accompanying notes 51-55 (discussing Lucy Stone's campaign in Massachusetts).

73. See Cobbe, supra note 15 , at 79-82.

74. See PLECK, DOMESTIC TYRANNY, supra note 33, at 111-21. On the deliberations of the ABA, see AMERICAN BAR ASS'N, REPORT OF THE NINTH ANNUAL MEETING OF THE AMERICAN BAR ASSOCIATION 286-93 (Philadelphia, Dando 1886); AMERICAN BAR ASS'N, REPORT OF THE TENTH ANNUAL MEETING OF THE AMERICAN BAR Association 57-59, 69 (Philadelphia, T. \& J.W. Johnson \& Co. 1887).

75. PLECK, DOMESTIC TYRANNY, supra note 33, at $109 \mathrm{n} .4$ (listing jurisdictions that considered adopting whipping-post legislation); Pleck, Criminal Approaches, supra note 50, at 40. 
especially brutal "type" impervious to normal social restraints; they claimed that the whipping post would deter wife beating because it was a mode of punishment to which even the most socially depraved would respond. For example, at a meeting of the Medico-Legal Society in 1899, the chief justice of Delaware urged, "Nothing acts upon the perceptions and motives of a brutalized man like whipping. ... [T] [There are certain natures, some, it may be, irreclaimable, whose consciences and conduct can be best governed by the application of the rod." 76 Others at the meeting asserted that the whipping post was an efficacious means of controlling "the vicious classes," recommended it for punishing youths, "wife-beaters, assaulters of very young girls and all habitual criminals," as "“the only punishment to which [they] would readily respond, and through which their sense of obligation to society could be aroused."'78 In this view, the wife beater needed to be physically dominated-his manhood broken-in order to be subject to social control. As the Reverend Phebe Hanaford explained:

We may well assume that the wife-beater does not like bodily pain, and a short time spent at the whipping-post-he being compelled to be passive, and some other man with strong muscles vigorously active,-the wife-beater learns two lessons: one, how it feels to be beaten, and the other, that the law will not allow him to whip his wife without inflicting the same upon himself. The wife will not be likely to receive a second beating. ${ }^{79}$

While advocated for the purpose of protecting women, the appeal of the whipping post lay in its capacity to break men. The gender symbolism of wife beating, reenacted at the whipping post, now articulated class and racial conflict among men. As Clark Bell concluded his case for adopting the whipping post in New York: "I am unable to find any record of one white man who has ever come back to the whipping-post for beating his wife." ${ }^{, 80}$

As wife beating emerged as a "law and order" issue, class- and race-based discourses about marital violence became even more pronounced. In the years

76. Clark Bell, Wife Beaters and Their Punishment, 8 MEDiCo-LEGAL STUd. 165, 168 (1906) [hereinafter Bell, Wife Beaters] (paper read before Medico-Legal Society and Psychological Section in October, 1903, reporting remarks of Chief Justice Charles B. Lore of Delaware, at 1899 meeting).

77. Id. at 169 (remarks of Judge Ignatius C. Grubb of the Delaware Supreme Court at 1899 meeting of Medico-Legal Society).

78. Id. at 169-70 (remarks of Hon. John G. Shortall, president of Humanitarian Society of Chicago, at 1899 meeting of Medico-Legal Society).

79. Rev. Phebe A. Hanaford, The Whipping Post for Wife-Beaters, 17 MEdiCo-Legal J. 108, 109 (1899) (paper read before the Medico-Legal Society (Psychological Section) in New York, May 17, 1899) (emphasis added).

80. Bell, Wife Beaters, supra note 76, at 172. For similar claims, see Simeon E. Baldwin, Whipping and Castration as Punishments for Crime, 8 YALE L.J. 371, 377 (1899); Clark Bell, The Whipping Post and the Wife Beater, 7 MEDICO-LEgAL STUD. 113, 113 (1902) [hereinafter Bell, Whipping Post] (attributing similar observation to Governor of Delaware, a state that still used whipping post for various crimes, including wife beating). See also supra note 70 . 
before and after the Civil War, Susan B. Anthony and Elizabeth Cady Stanton publicized the cases of wealthy and prominent men who had beaten their wives. ${ }^{81}$ But while members of the social elite were certainly aware of marital violence within their ranks, ${ }^{82}$ in the closing decades of the nineteenth century, commentators increasingly depicted wife beating as the practice of lawless or unruly men of the "dangerous classes." ${ }^{\text {" } 33}$ Statistics on arrests and convictions for wife beating in the late nineteenth century suggest that while criminal assault law was enforced against wife beaters only sporadically, it was most often enforced against immigrants and African-American men. In Northern states, members of immigrant ethnic groups (e.g., German- and IrishAmericans) were targeted for prosecution; ${ }^{84}$ in the South, African-Americans were singled out for prosecution in numbers dramatically exceeding their representation in the population. ${ }^{85}$ While marital violence may well have been

81. Pleck, "Crimes Against Women," supra note 51, at 452-53. Stanton spoke out about many cases of aggravated cruelty among the Dutch aristocracy in New York, and, with Anthony, called for the conviction of attomey Albert McFarland, a wife beater who murdered his ex-wife's fiance; Stanton also aided the abused ex-wife of a Massachusetts senator. Id. at 453. By the postwar era, however, some woman's rights advocates were beginning to describe violence against women in class-based or ethnicized terms. For example, when Henry Blackwell condemned wife beating in 1875 , he asserted that "[t]hese outrages are confined to no class or nationality," yet then proceeded to observe that "a large majority of them are committed by foreigners-probably because women are less esteemed and respected in foreign countries than in our own." Henry B. Blackwell, Maltreating Women, WoMAN's J., May 15, 1875, at 156, 156. A number of suffragists (including Lucy Stone) ultimately endorsed the whipping post as a punishment for wife beaters, although many others in the woman's movement condemned the proposal. See Pleck, The Whipping Post, supra note 45, at 132-33.

82. For an account of domestic violence among the elite in the antebellum South, see WYATT-BROWN, supra note 70, at 282 ("In 1855 David Gavin listed four local wife-beaters in a very small radius of his plantation. Two of the husbands were physicians, all four belonged to the gentry set, and their wives all had excellent pedigrees."). The practice was visible in the North as well. See GLENN, supra note 26, at 64-65 (observing that, during 1860s, New York Times reported incidents of domestic violence among the lower classes and the "respectable"). Glenn notes, for example, that in 1866, "the Times reported that the Second United Presbyterian Church of Pittsburgh, Pennsylvania had excommunicated its minister ... because he had committed adultery and had behaved in an 'unkind, cruel, and violent' manner towards his family. Dr. Priestley regularly kicked, choked, and spat at his wife. . . ." Id. See generally Nadelhaft, supra note 24 (discussing variety of cultural sources suggesting that wife beating was "known phenomenon" in nineteenth-century America).

83. See Pleck, Criminal Approaches, supra note 50, at 36.

84. See Elizabeth Pleck, Wife Beating in Nineteenth-Century America, 4 VICTIMOLOGY 60, 65 (1979) [hereinafter Pleck, Wife Beating] ("The wifebeater, according to police records, was generally an immigrant or a black. In Pennsylvania most of the men arrested for wifebeating were immigrants: Germans, Irish, English, Hungarians, and Italians." (citation omitted)); supra note 81 (quoting Henry Blackwell on ethnicity of wife beaters); see also 40 CoNG. REC. 2446-47 (1906) (remarks of Rep. Adams) (advocating bill to punish wife beaters in District of Columbia with flogging at whipping post; introducing chart identifying wife beaters prosecuted in Pennsylvania by "nationality of the condemned"; and observing: "[W]ife beating exists to a greater extent, though not exclusively, among the foreign population, and it is certainly desirable that the baneful influence of the practice should be promptly checked before contaminating our native-born people.").

85. See, e.g., Pleck, The Whipping Post, supra note 45, at 135-37 (discussing racially disproportionate enforcement of wife-beating statutes, particularly in South, where black men were far more likely than whites to be prosecuted for physically abusing their wives); Pleck, Wife Beating, supra note 84 , at 65 ("Between 1889 and 1894, fifty-eight out of sixty men arrested for wifebeating in Charleston, South Carolina were black." (citation omitted)). For contemporary discussions of the racial incidence of punishment, see 40 CONG. REC. 2444, 2449 (1906) (remarks of Rep. Sims) (debating bill to punish wife beaters in District of Columbia by flogging at whipping post and discussing committee report in support 
more prevalent among the poor, the tenor of public conversation about wife beating makes clear that concerns other than simple regard for battered women animated the prosecutions. ${ }^{86}$ By the 1890 s, the conception of wife beaters was sufficiently racialized that the Louisiana and South Carolina constitutions listed it among the crimes warranting disenfranchisement; ${ }^{87}$ the author of a 1901 Alabama constitutional provision disenfranchising criminals "'estimated the crime of wife-beating alone would disqualify sixty percent of the Negroes." "88 This episode in constitutional reform creates a rather sorry capstone to the egalitarian commitments espoused in the Fulgham opinion.

Thus, as the American legal system repudiated the husband's prerogative to chastise his wife, it did begin to respond differently to wife beating-yet did

of bill that indicated that "in the fourth precinct there were 14 white and 72 colored out of a total of 86 arrests for wife beating, and in the sixth precinct there were 23 white and 73 colored out of a total of 96 arrests for this offense"); Baldwin, supra note 80 , at 377 (discussing criminalization of wife beating in Maryland: "In 1884 there were one hundred and thirty-one arrests upon this charge in the city of Baltimore. Early in 1885 a man, and the first white man, was sentenced under the new law to twenty lashes, besides a year in jail." (emphasis added)).

86. Cf. Pleck, The Whipping Post, supra note 45, at 141-42. It is difficult, if not impossible, to determine the frequency of wife beating during the nineteenth century, or to ascertain its incidence by class or race. Records of local law enforcement are scant, see supra note 50, and no public or private entities monitored the problem in a systematic fashion. Even if better records existed, a problem would remain: Class- and race-based beliefs about the "degraded" character of men who beat their wives could well bias law enforcement and monitoring practices. Cf. Haag, supra note 50, at 449 (discussing distortions in nineteenth-century New York City court records, due to selective dismissals of assault cases "along racist and sexist lines").

Some sociologists and historians speculate that violence may well be more prevalent in households of the poor. In this view, married men who lack other resources to assert their authority in the family (e.g. money, prestige) may be more prone to assert authority through physical force. See, e.g., David Peterson, Physically Violent Husbands of the $1890 \mathrm{~s}$ and Their Resources, $6 \mathrm{~J}$. FAM. VIOLENCE 1 (1991). But cf. GORDON, HEROES, supra note 33, at 287 (noting that "[t]his theory would explain why poor and low-status men, who lack other resources, may use violence more readily than rich and prestigious men" but also noting that " $[t]$ he fact being explained . . . has been challenged: as with all family violence, it is difficult to distinguish reported incidents from actual incidence").

To summarize: The nonstatistical evidence gathered in this section demonstrates that legal elites regularly invoked class- and race-based stereotypes in reasoning about domestic violence. These social biases shaped law enforcement efforts, resulting perhaps most prominently in advocacy of the whipping post for wife beaters. My observations about the social biases informing law enforcement efforts do not rest on the claim that wife beating was equally distributed throughout the population-though it may have been. Class and racial bias could have motivated and shaped law enforcement efforts, even if marital violence were more prevalent in households of the poor.

Historian David Peterson subscribes to the latter view. In a case study from the 1890 s, Peterson argues that wife beating was more prevalent in households in which low-status men lacked other resources to assert their authority, see Peterson, supra, but Peterson also contends that efforts to regulate wife beating have commonly been shaped by diverse forms of social bias, see David Peterson del Mar, Violence Against Wives in the United States: History's Contribution to Feminist Theory 11 (Mar. 28, 1996) (unpublished manuscript delivered at the Annual Meeting of the Organization of American Historians, Mar. 28, 1996, on file with author) ("When men have condemned wife beating, that rhetoric has most commonly functioned not to protect wives from male brutality but rather to identify the wife beater as a highly recognizable and deviant type.").

87. See Andrew L. Shapiro, Note, Challenging Criminal Disenfranchisement Under the Voting Rights Act: A New Strategy, 103 YALE L.J. 537, 541 (1993); see also Allen v. Ellisor, 664 F.2d 391, 404-05 (4th Cir.) (en banc) (Winter, J., dissenting in part and concurring in part) (discussing racist genesis of South Carolina statute disenfranchising wife beaters), rev'd, 454 U.S. 807 (1981).

88. JiMMIE FRANK GROSS, ALABAMA POLITICS AND THE NEGRO, 1874-1901, at 244 (1969) (quoting John F. Bums), quoted in Shapiro, supra note 87, at 541. 
not adopt policies calculated to provide married women much relief from family violence. Women of the social elite might escape husbands who beat them by obtaining a divorce, if they were not deemed blameworthy, and if they were willing to subject themselves and their children to the economic perils and social stigma associated with single motherhood. Women of poorer families might have a husband fined, incarcerated, or perhaps even flogged, if they were willing to turn him over to a racially hostile criminal justice system. ${ }^{89}$ The law thus provided relief to some battered wives, but the majority had little recourse against abusive husbands.

We are left with a striking portrait of legal change. Jurists and lawmakers emphatically repudiated the doctrine of marital chastisement, yet responded to marital violence erratically - often condoning it, and condemning it in circumstances suggesting little interest in the plight of battered wives. Given this record, how are we to make sense of chastisement's demise? Woman's rights advocacy may have helped to discredit the prerogative, but the regulatory regime that emerged in its wake belies the notion that the legal system simply internalized the norms of sex equality that the movement advocated. We need, then, to scrutinize more closely the social assumptions prompting the repudiation of chastisement doctrine to make sense of the policies on marital violence that emerged in its wake.

89. See Rapport, supra note 66 , at $39-41$ (discussing records of Freedmen's Bureau in postwar Georgia):

By comparison, cases stemming from gender conflict between black women and men appeared infrequently in the [Freedmen's] bureau record books. There are two possible explanations for this difference. The first is that freedpeople simply did not experience a great deal of sex antagonism. An alternative explanation, consistent with the hypothesis that freedpeople selectively invoked bureau protection, is that they perceived all whites, both southem and northern, as members of the oppressing class, and preferred not to 'air their dirty laundry' before them.

$\ldots$

... On the one hand, freedwomen sought bureau intervention to gain leverage in disputes with their men; on the other hand, they could not have agreed with the agents that their troubles stemmed from some proclivity toward infidelity innate to blacks. To protect their men (and themselves) from such an assessment, they brought fewer cases of domestic disputes than they did cases of wage disputes and kidnappings.

Id.; cf. Kimberle Crenshaw, Mapping the Margins: Intersectionality, Identity Politics, and Violence Against Women of Color, 43 STAN. L. REv. 1241, 1257 (1991):

Women of color are often reluctant to call the police, a hesitancy likely due to a general unwillingness among people of color to subject their private lives to the scrutiny and control of a police force that is frequently hostile. There is also a more generalized community ethic against public intervention, the product of a desire to create a private world free from the diverse assaults on the public lives of racially subordinated people. The home is not simply a man's castle in the patriarchal sense, but may also function as a safe haven from the indignities of life in a racist society. 


\section{REgulating MaRital Violence IN AN ERA OF COMPANIONATE MARRIAGE}

As we have seen, formal repudiation of the chastisement prerogative did not necessarily express a commitment to protect women from husbands who beat them. Yet the demise of the common law doctrine did seem to signal an important shift in conceptions of marriage. In 1892, a Kentucky court described the husband's prerogative to chastise his wife as a "relic" of a longgone era:

[U]nder modern legislation, as well as judicial opinions, that fiction of legal unity by which the separate existence of the wife in a legal sense is denied is exploded. Her person is as sacred as that of the husband, and the protection afforded by law to the one should not be denied to the other. ... [T] say that a court of law will recognize in the husband the power to compel his wife to obey his wishes, by force if necessary, is a relic of barbarism that has no place in an enlightened civilization. ${ }^{90}$

Similarly, in the Reconstruction-era opinions we have examined, judges emphatically and with near univocality condemned chastisement doctrine, calling it variously "a rude privilege," a "brutality found in the ancient common law," and a "revolting precedent." the law of marital status did repudiation of chastisement doctrine portend?

As the Kentucky court suggested, the demise of chastisement was linked to wider changes in the law of marital status--in particular, to statutory reform of the doctrine of marital unity and the rule of gender hierarchy that it embodied. By mid-century, under the pressure of woman's rights advocacy, state legislatures had begun to enact legislation reforming the status incidents of marriage; over the course of the century, these married women's property acts gradually transformed a marital regime in which a husband ruled and represented his wife into one predicated in significant part on the juridical individuality of its partners. ${ }^{92}$ Corporal punishment was an integral part of a regime of mastery; it made less sense as an element of the marriage relationship as the relationship in which it was situated became more egalitarian in character.

But there is evidence that chastisement's demise began well before the rise of feminist agitation. As we have seen, neither Blackstone nor the American treatise writers who followed him in the nineteenth century were entirely

90. Carpenter v. Commonwealth, $92 \mathrm{Ky} .452,456-57$ (1892) (emphasis added) (affirming conviction of husband for cutting his wife's throat with knife, with intent to take her life).

91. See supra text accompanying notes 64,68 .

92. See supra note 38 and accompanying text. 
confident of the continuing legitimacy of the chastisement prerogative. ${ }^{93}$ An examination of the treatises suggests that the chastisement prerogative was undermined by changing conceptions of marriage that may well have contributed to the reform demands of the feminist movement and, in a measure, eased their reception. ${ }^{94}$

As early as 1816, Tapping Reeve, author of the first American treatise on family law, observed that there was a tension between the chastisement prerogative and prevailing mores of the family. Reeve offered his diagnosis of the problem in the form of a gloss on Blackstone. Paraphrasing the Commentaries, ${ }^{95}$ Reeve observed that in England, "the husband seems to have had the same right over the person of his wife, that he had over the person of his apprentice; to chastise her moderately or confine her; a right still claimed and enforced in that country, among the lower ranks of society",96 but under the reign of Charles II,

wives began to receive a more liberal treatment. Their rights were better understood than heretofore. They assumed more the character of companions than of servants to their husbands. Their claims to exemption from the operation of the before mentioned principles have gained additional strength from the increased refinements of modern times. ${ }^{97}$

Echoing Reeve in 1870, a prominent family law treatise by James Schouler also invoked the concept of companionate marriage to explain the demise of chastisement doctrine:

In a ruder state of society the husband frequently maintained his authority by force.... But [in recent times] the wife has been regarded more as the companion of her husband; and this right of chastisement may be regarded as exceedingly questionable at the present day. The rule of love has superseded the rule of force. ${ }^{98}$

Neither Reeve nor Schouler asserted that the wife was an equal of her husband, but each took pains to emphasize that the marriage relationship was less hierarchical than Blackstone had presented it. Reeve defined the wife's

93. See supra text accompanying notes 18-23.

94. For one analysis of how feminist conceptions of equality draw on the gender norms they criticize, see Siege!, Home As Work, supra note 38, at 1110-12, 1132-34, 1205, 1213-15.

95. See supra text accompanying notes 16-21.

96. REEVE, supra note 16, at 65.

97. Id. (emphasis added).

98. JAMES SChOULER, A TREATISE ON THE LAW OF THE DOMESTIC RELATIONS 59 (Boston, Little, Brown \& Co. 1870) [hereinafter SCHOULER, DOMESTIC RELATIONS] (emphasis added). This language appeared in subsequent editions of the treatise until 1882 when it was amended to read, "The rule of persuasion has superseded the rule of force." JAMES SCHOULER, A TREATISE ON THE LAW OF THE DOMESTIC RELATIONS 102 (Boston, Little, Brown \& Co. 3d ed. 1882) (emphasis added). 
status as companion negatively - as "not a servant." A half century later, Schouler went further, describing companionate marriage as a relationship in which "[t]he rule of love [had] superseded the rule of force." 99

The vision of companionate marriage embraced by these treatise writers falls short of the egalitarian ideal endorsed by the nineteenth-century woman's rights movement, ${ }^{100}$ and yet bears a closer resemblance to it than to the hierarchical relationship contemplated by the marital status rules of the common law. In Blackstone's world, the rights of persons in private relations resembled the rights of persons in public relations, with both described in terms of "gradations of hierarchy ... and of the peculiar privileges and disabilities that went along with particular roles."101 The household remained patriarchal in form, "a little commonwealth" in which the master ruled the members (wife, children, servants, etc.) and represented them in the larger commonwealth. ${ }^{102}$ Family and state stood in homologous relation, with authority relations structuring the polity from top to bottom.

The vision of companionate marriage summoned by Schouler and others is of a fundamentally different order. In this emergent, idealized conception at least, affect links household members, not authority. And so, as the treatise writers explain it, the rise of companionate marriage undermined the authoritybased marital status regime of the common law, and with it, the master's prerogative to chastise his wife.

Yet historical change rarely occurs in such neat patterns. Companionate understandings of marriage emerged only gradually, producing conflicts and contradictions in the norms structuring marriage that endured for centuries. ${ }^{103}$

99. SCHOULER, DOMESTIC RELATIONS, supra note 98 , at 59.

100. Cf. Siegel, Home As Work, supra note 38, at 1103-08 (examining how movement's understanding of equality transformed cultural traditions it drew upon). (1979).

101. Duncan Kennedy, The Structure of Blackstone's Commentaries, 28 BUFF. L. REV. 205, 283

102. Cf. John Demos, A LitTle Commonwealth: Farally Life in Plymouth Colony 59-125 (1970) (describing social relationships in seventeenth-century Plymouth, Massachusetts).

103. The rise of companionate marriage is the subject of considerable historiographical dispute, with commentators dividing over the formal characteristics of the change and its proper periodization. The English historian Lawrence Stone was among the first scholars to chart the development of this new style in marital relations. See LAWRENCE STONE, THE FAMILY, SEX AND MARRIAGE IN ENGLAND, 1500-1800, at 217-18, 239-44 (1977). Since that time, American historians of women, gender, and the family have found the concept useful in depicting a range of ideological and sociological changes occurring at various points in American history, from the Early Republic through the early decades of the twentieth century. See, e.g., NANCY F. COTT, THE GROUNDING OF MODERN FEMAINISM 156-61 (1987) (discussing 1920s);

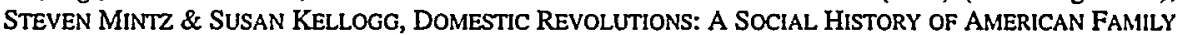
LIFE (1988) (discussing late nineteenth and early twentieth centuries); Myra C. Glenn, Wife-Beating: The Darker Side of Victorian Domesticity, 15 CANADIAN REV. AM. STUD. 17, 22-23 (1984) (discussing changing marriage patterns in post-Revolutionary period); Griswold, Mental Cruelty, supra note 58, at 139 (discussing Victorian period); Christina Simmons, Companionate Marriage and the Lesbian Threat, FroNTIERS, Fall 1979, at 54, 54-55, 57 (1979) (discussing 1920s); Daniel Scott Smith, Parental Power and Marriage Patterns: Analysis of Historical Trends in Hingham, Massachusetts, 35 J. MARRIAGE \& FAM. 419 (1973) (discussing late eighteenth century). Occupying the middle ground in this debate is Suzanne Lebsock, who sees companionate marriage as a phenomenon that might describe "the general direction in which marriages were moving" over several centuries, thus making the concept resistant to precise 
If one examines the prescriptive literature on marriage written during the nineteenth century, one finds rich evidence that, for most of the century, Americans understood marriage as a relationship organized in terms of authority and affect. These tracts provide a revealing glimpse of the hybrid and conflicting norms that defined marriage during the period of chastisement's demise.

Popular tracts on marriage written in the opening decades of the century still invoked the authority-based norms of the common law, which, however, they sought to temper by emphasizing the importance of affection and respect in the marital relationship. In 1837, for example, William Alcott began his account of the "duties of the woman in the marriage relation" with a chapter on "Submission." While protesting that he "would be the last person in the world to justify a tyrannical assumption of superiority on the part of our own sex" and advising that men assert their claims "in the most gentle manner," Alcott nevertheless asserted that "reason, nature and revelation" united in placing "the balance of concession" in the marriage relationship on women, adding that "the more cheerful and voluntary the submission, the happier the results. ... Perhaps there is no one thing on which domestic happiness so much depends as this ...."104 In this era, women who offered marital advice spoke even more forthrightly about the wife's status as a subordinate member of the relationship. ${ }^{105}$

Yet over the course of the century, the prescriptive literature on marriage began to talk about the relationship in terms that diverged ever more dramatically from the common law. In the 1850s, for example, William Alcott described the authority relations of marriage in considerably more oblique terms. Now he presented a wife's submission as altruism, and service to others as woman's path to self-fulfilment: "[H]owever elevated the character of woman-however influential she may be, and however great the duties she owes to herself to qualify herself for fulfilling her mission-she will do most for herself while laboring most for others." ${ }^{106}$ By 1883, Eunice Beecher, wife of the Reverend Henry Ward Beecher, was forthrightly criticizing the

temporalization. See SuZANNE LEBSOCK, THE FREE WoMEN of PETERSBURG: STATUS AND CULTURE IN A SOUTHERN TOWN, 1784-1860, at 17-18 (1984).

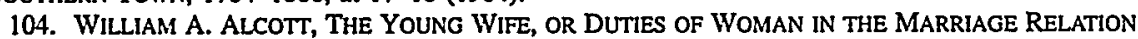
30-31 (Boston, George W. Light 1837). In describing a woman's duty of submission, Alcott remarked that he did not intend to "imply an intellectual and moral inferiority on the part of woman" or to "preclude the idea that in morals she may even be the superior. The concession is that of physical prowess, rather than of moral influence." Id. at 27. Alcott then proceeded to develop his account of marital status, as divinely and socially ordained, in this physiological framework.

105. See CATHERINe E. BeEcher, A TREATISE ON Domestic Economy, for the USE of Young LADIES AT HOME, AND AT SCHOOL 26 (Boston, Thomas H. Webb, \& Co. rev. ed. 1842) (describing "the relations of husband and wife" as "involving the relative duties of subordination"); L.H. SIGOURNEY, LETTERS TO YOUNG LADIES 37 (Hartford, William Watson 2d ed. 1835) (describing "duty of submission" that is "imposed both by the nature of our station and the ordinances of God"). 1853).

106. William A. AlcotT, GifT BOoK FOR YOuNG LAdIES 85 (Buffalo, Derby, Orton \& Mulligan 
authority-based conception of marriage, going so far as to assert that the "word 'govern' should never be shown in word or act-never enter the heart between husband and wife." 107 Beecher warned that a husband should not expect his "will to be the controlling motive for his wife's conduct" or assert his "rightful authority as head of the house" if he wished for marital bliss, observing: "If all could fully realize the true difference between the service rendered by woman to authority and that poured out unceasingly, spontaneously, for love, what a difference would be found in many homes!"108 Yet Beecher did not squarely reject a husband's role as "head of the house" or the wife's role in providing "service" to him; instead she discussed these traditional marital roles in a new idiomatic framework. Beecher waxed eloquent as she depicted a home "governed" by love, inveighing against an authority-based conception of marriage but then reproducing the structures of marital authority within the discourse of marital affect:

\begin{abstract}
A home governed by ... gentle influences, is to a home governed by man's authority, as a person is to a machine. One is life; the other only mechanism. ... In such homes-and we verily believe it rests more with husbands than with wives to build them up-the thought of supremacy never intrudes. Marriage in such homes is a true union, each mutually helping the other, bound together with united love and confidence; the husband's manifested by unremitted care and tenderness; the wife's, as is woman's nature, by that devoted service which is most happy in ministering to the comfort and pleasures of her household. She willingly acknowledges him as the head, in so far as deciding any matter for the home welfare-where their opinions are not quite in unison-and in all that naturally comes under his especial care and supervision. But she yields-not through authority, but love. ${ }^{109}$
\end{abstract}

"But she yields-not through authority, but love." Over the course of the nineteenth century, an authority-based conception of marriage evolved into an affect-based conception of the relationship in which husband and wife were united and positioned by a different kind of bond. The status structure of the relationship survived this transformation but was also shaped by it. As conversation about marital relations shifted from the framework of obedience and submission to that of asking and giving, the domestic relation began to take its character, not from the husband's ability to compel his wife's obedience, but instead from the wife's magnanimity in yielding to his desires. Differently put, it was not the husband's authority that defined the nature of marriage so much as the wife's altruism.

107. MRS. HenRY Ward Beecher, The Home: How to MaKe AND Keep It 246 (Minneapolis, Buckeye Publishing Co. 1883).

108. Id. at 247.

109. Id. at $248-49$. 
The erosion of authority-based conceptions of marriage can be understood as a part of the decline of status relationships associated with feudal and monarchical societies; but the conventional "status to contract" story told about the nineteenth-century reform of marriage law obscures as much as it reveals about the evolution of the marital relationship in the modern era. ${ }^{110}$ Social contract theorists never applied concepts of individualism to the family with the confidence that they applied them to market and state relationships; ${ }^{111}$ instead, with the rise of liberalism, it became commonplace to define the family in terms of its differences from other social relationships. Countless nineteenth-century accounts of the home depict the family as fundamentally distinct from other spheres of social life, a domain in which altruism and other-regard prevailed, rather than self-interested individualism. For example:

"We go forth into the world, amidst the scenes of business and of pleasure; . . . we join the busy crowd, and the heart is sensible to a desolation of feeling: we behold every principle of justice and of honor, and even the dictates of common honesty disregarded, and the delicacy of our moral sense is wounded; we see the general good, sacrificed to the advancement of personal interest; and we turn from such scenes, with a painful sensation, almost believing that virtue has deserted the abodes of men; again, we look to the sanctuary of home; there sympathy, honor, virtue, are assembled; there the eye may kindle with intelligence, and receive an answering glance; there disinterested love, is ready to sacrifice every thing at the altar of affection."112

"Disinterested love" and "affection" differentiated the family relation from all other social relationships. Precisely as nineteenth-century America embraced norms of possessive individualism, it demanded that the family serve as a

110. See Siegel, Modernization, supra note 38, at 2133-41 (criticizing "status to contract" story as account of modernization of marital status law); $c f$. MARK KELMAN, A GUIDE TO CRITICAL LEGAL STUDIES 224 (1987) (criticizing "status to contract" story as account of development of liberal social institutions, but suggesting it might have some explanatory power with respect to family).

111. Cf. Zillah R. EISENSTEIN, THE RADICAL FUTURE OF LibERAL FEMINISM 47-49, 201-19 (1993) (describing relationship between liberal individualism and family); SUSAN MOLLER OKIN, JUSTICE, GENDER, AND THE FAMILY 25-40 (1989) (analyzing how various theories of justice address the family); CAROLE PATEMAN, THE SEXUAL CONTRACT (1988) (analyzing social contract theory in feminist light); Frances E. Olsen, The Family and the Market: A Study of Ideology and Legal Reform, 96 HARV. L. REV. 1497 (1983) (arguing that assumptions about the market/family dichotomy have impeded reform of family relations).

112. Kirk Jeffrey, The Family as Utopian Retreat from the City: The Nineteenth-Century Contribution, 55 SouNDinGs 21, 28 (1972) (emphasis added) (quoting Home, LADIES’ MAG., May 1830, at 218). Home was depicted as a place where man

"seeks a refuge from the vexations and embarrassments of business, an enchanting repose from exertion, a relaxation from care by the interchange of affection: where some of his finest sympathies, tastes, and moral and religious feelings are formed and nourished; - where is the treasury of pure disinterested love, such as is seldom found in the busy walks of a selfish and calculating world."

Charles Burroughs, Address on Female Education (Oct. 26, 1827) (emphasis added), quoted in CoTr, supra note 31 , at 64 . 
"sanctuary" or "haven in a heartless world," providing a refuge from the ethos of market capitalism. ${ }^{113}$

It was this set of changes in popular conceptions of marriage that treatise discussions of chastisement register, and that the feminist movement exploited in its assault on the marital status doctrines of the common law. By the 1840s, the woman's rights movement was protesting the husband's prerogative to chastise his wife, along with many other hierarchical features of marital status law. ${ }^{14}$ Because chastisement so powerfully contradicted norms of companionate marriage, it provided an easy target for feminists interested in demonstrating the injustice of the common law. Thus, when the Declaration of Sentiments condemned chastisement in 1848, it merely pointed to the authority-based conception of marriage that chastisement enforced-tacitly exploiting the dissonance between authority-based and affect-based conceptions of marriage to discredit the common law:

He has made her, if married, in the eye of the law, civilly dead.

He has taken from her all right in property, even to the wages she earns.

... In the covenant of marriage, she is compelled to promise obedience to her husband, he becoming, to all intents and purposes, her master-the law giving him power to deprive her of her liberty, and to administer chastisement. ${ }^{115}$

Or, as Sarah Grimké described the marriage relationship in 1855:

[Wives] have too soon discovered that they were unpaid housekeepers \& nurses, \& still worse, chattels personal to be used \& abused at the will of a master ... O ! the agony of realizing that personal \& pecuniary independence are annihilated by that " $\mathrm{Law}$ which makes the husband and wife one \& that one is the husband." 116

113. See Stephanie CoOntz, The Social Origins of Private Life: A History of AMerican FAMILIES 1600-1900, at 210 (1988). For an elaboration of this argument, see STEPHANIE COONTZ, THE WAY WE NEVER WERE 52-67 (1992). See also Olsen, supra note 111, at 1499 ("The home was said to provide a haven from the anxieties of modern life-'a shelter for those moral and spiritual values which the commercial spirit and the critical spirit were threatening to destroy."' (quoting WALTER E. HOUGHTON, THE VICTORIAN FRAME OF MIND, 1830-1870, at 343 (1957) (emphasis omitted))). For variations on this theme, see JOHN DEMOS, PAST, PRESENT, AND PERSONAL: THE FAMILY AND THE LifE Course IN AMERICAN HISTORY 32 (1986) (arguing that men "would retreat periodically [to the family] for repose, renewal, and inner fortification against the dangers [they] encountered elsewhere"); see also Jeffrey, supra note 112, at 28-29 (analyzing how urban Americans sentimentalized the family in attempt to recapture ideals of rural life); Barbara Laslett, The Family as a Public and Private Institution: An Historical Perspective, 35 J. MARRIAGE \& FAM. 480 (1973) (characterizing institution of private family as modern twentieth-century development, resulting from separation of familial and work activities).

114. See supra text accompanying notes $37-43$.

115. SENECA FALLS CONVENTION REPORT, supra note 37, at 6 (emphasis added).

116. Sarah M. Grimké, Marriage (1852-57) (unpublished manuscript), in THE FEMALE EXPERIENCE: AN AMERICAN DOCUMENTARY 87, 96 (Gerda Lemer ed., 1977). 
When Elizabeth Cady Stanton appealed to the New York legislature to reform the state's divorce laws in 1861, she self-consciously exploited the contradiction between sentimental conceptions of marriage and the violence that law condoned in the relationship:

Call that sacred, where woman ... consents to live in legalized prostitution! her flesh shivering at the cold contamination of that embrace! held there by no tie but the iron chain of the law, and a false and most unnatural public sentiment? Call that sacred, where innocent children, trembling with fear, fly to the corners and dark places of the house, to hide from the wrath of drunken, brutal fathers, but forgetting their past sufferings, rush out again at their mother's frantic screams, "Help! oh, help!" Behold the agonies of those young hearts, as they see the only being on earth they love, dragged about the room by the hair of her head, kicked and pounded, and left half dead and bleeding on the floor! Call that sacred, where fathers like these have the power and legal right to hand down their natures to other beings, to curse other generations with such moral deformity and death!

... Learn how false and cruel are those institutions, which, with a coarse materialism, set aside the holy instincts of the woman, to seek no union but one of love. ${ }^{117}$

Playing on the disjuncture between the law of marriage and popular conceptions of the relationship was a common tactic of feminist protest $^{118}$ - here deployed by Stanton to raise questions about divorce, marital rape, ${ }^{119}$ and domestic violence. The cumulative effect of this kind of feminist protest was to imbue chastisement with symbolic significance, so that questions about its legitimacy implicated the entire marital status regime of the common law. ${ }^{120}$ Together, evolving social norms and strategically focused protest undermined chastisement in a way that neither could alone.

117. Address of Elizabeth Cady Stanton, on the Divorce BILl, Before tHe Judiciary COMMITTEe OF THE NEW YORK SENATE, IN THE ASSEMBLY CHAMBER, FEB. 8, 1861, at 8 (Albany, Weed, Parsons \& Co. 1861) (emphasis added); see also 1 HISTORY OF WOMAN SUFFRAGE, supra note 40, at 719 (similar address to Tenth National Woman's Rights Convention, 1860).

118. The movement's rank appeal to sentimental conceptions of marriage and family can be understood as a shrewd tactic to present the movement's radical demands in a politically palatable form. See GLENN, supra note 26, at 78-79 (discussing Stanton speech quoted supra text accompanying note 117). But it also seems reasonable to assume that the cultural norms to which the movement appealed also played a role in shaping its conceptions of equality. See supra note 94 and accompanying text.

119. The nineteenth-century woman's rights movement used the term "legalized prostitution" to criticize marriage as a relation of sexual coercion and compulsory maternity; in this period, the movement's demands for "voluntary motherhood" were focused on issues of marital rape, rather than abortion. For an account of how the "legalized prostitution" polemic figured in the movement's demand for sexual and reproductive autonomy in marriage, see Reva Siegel, Reasoning from the Body: A Historical Perspective on Abortion Regulation and Questions of Equal Protection, 44 STAN. L. REV. 261, 306-10 (1992) [hereinafter Siegel, Reasoning from the Body].

120. The movement also argued that violence in marriage proved women's need for the vote. See supra text accompanying notes $41-43$. 
From this standpoint, it is easier to appreciate why, by the Reconstruction Era, American authorities had unanimously repudiated marital chastisement, even if they continued to resist most reform demands of the woman's rights movement. If a judge believed that marriage ought be a relation of love, not force, he could denounce chastisement as a relic of a barbaric past-without endorsing the equality norms and associated reform demands of the woman's rights movement. Indeed, if he believed that egalitarian norms of marriage were fundamentally misguided, he might still denounce the husband's chastisement prerogative in order to make the traditional authority structure of marriage easier to defend. In short, the repudiation of chastisement might reflect a commitment to affect-based, authority-based, or equality-based norms of marriage, or any ambivalent mixture thereof.

So considered, it is easier to appreciate why the repudiation of chastisement did not entail any clear consequences for the regulation of violence in marriage. The demise of chastisement created a regulatory vacuum, a need for new policies to regulate violence in marriage that had yet to be devised-and that would be devised from the conflicting marital norms we have been examining. We now turn to scrutinize the policies that emerged in the wake of chastisement's demise.

\section{The Discourse of Affective Privacy In DOMestic Assault LaW}

But she yields-not through authority, but love.

Mrs. Henry Ward Beecher, The Home: How to Make and Keep It $(1883)^{121}$

Mere ebullitions of passion, impulsive violence, and temporary pain, affection will soon forget and forgive .... But when trifles are taken hold of by the public, and the parties are exposed and disgraced, and each endeavors to justify himself or herself by criminating the other, that which ought to be forgotten in a day, will be remembered for life.

State v. Rhodes (North Carolina 1868) ${ }^{122}$

Our law before today practiced a cruel paradox. Under the guise of promoting family harmony, it permitted the wife beater to practice his twisted frustrations secure in the knowledge that he was immune from civil action except for a divorce, and that any criminal penalty would ordinarily be a modest fine.

Coffindaffer v. Coffindaffer (West Virginia 1978) ${ }^{123}$

121. BEECHER, supra note 107 , at 249.

122. 61 N.C. (Phil. Law) 453, 457 (1868).

123. 244 S.E.2d 338, 343-44 (W. Va. 1978). 
To this point we have examined how emerging notions of companionate marriage undermined the authority-based conception of marriage in which the chastisement prerogative was rooted. As the treatises register this conflict, it is stark and its results simple: The rise of companionate marriage discredited marital chastisement. And the cases do supply evidence supporting this view. For example, to justify its opinion finding an emancipated slave guilty of battery for beating his wife in Fulgham v. State, ${ }^{124}$ the Supreme Court of Alabama announced that " $[t]$ he wife is not to be considered as the husband's slave ... [and] ... is entitled to the same protection of the law that the husband can invoke for himself"; ${ }^{125}$ it then proceeded to explain the husband's duty to the wife by quoting Schouler's treatise to the effect that a husband "is bound to love his wife and to bear with her faults, and if possible, by mild means to correct them"' 26 and concluded its opinion with Schouler's observation that "'the rule of love has superseded the rule of force."'127

The Fulgham opinion endorses marriage as a relation of love and equality, and denounces the older, authority-based understandings of the common law. Yet the race- and class-based concerns shaping prosecution of wife beating in the Reconstruction $\mathrm{Era}^{128}$ should caution us immediately against any simplistic construction of the case. Before we read Fulgham as a story about the triumph of affective or egalitarian conceptions of marriage over authoritybased understandings of the relationship, we need to examine more carefully how the language of companionate marriage functioned in nineteenth-century opinions concerning the regulation of marital violence. As we will see, courts drew on the discourse of companionate marriage to craft a new body of domestic violence policies that operated, to a startling degree, in both a genderand a class-salient manner.

A key concept in the doctrinal regime that emerged from chastisement's demise was the notion of marital privacy. During the antebellum era, courts began to invoke marital privacy as a supplementary rationale for chastisement, in order to justify the common law doctrine within the discourse of companionate marriage, when rationales rooted in authority-based discourses of marriage had begun to lose their persuasive power. For example, in the

124. $46 \mathrm{Ala} .143$ (1871); see supra text accompanying notes $62-65$.

125. Id. at 146-47; see also id. at 147 (noting that state constitution protects all citizens "without distinction of rank, caste or sex").

126. Id. at 147 (quoting SCHOULER, DOMESTIC RELATIONS, supra note 98, at 59).

127. Id. at 148 (quoting SCHOULER, DOMESTIC RELATIONS, supra note 98, at 59).

128. See supra Subsection I.B.2. 
1824 case of Bradley v. State, ${ }^{129}$ the Mississippi Supreme Court upheld the chastisement prerogative, citing Blackstone and then observing:

However abhorrent to the feelings of every member of the bench, must be the exercise of this remnant of feudal authority, to inflict pain and suffering, when all the finer feelings of the heart should be warmed into devotion, by our most affectionate regards, yet every principle of public policy and expediency, in reference to the domestic relations, would seem to require, the establishment of the rule we have laid down, in order to prevent the deplorable spectacle of the exhibition of similar cases in our courts of justice. ${ }^{130}$

These early privacy-based chastisement opinions begin to rationalize the common law prerogative within the discourse of companionate marriage, sometimes in combination with rationales rooted in authority-based conceptions of marriage. ${ }^{131}$ A judge reasoning about marriage as a companionate relationship could invoke values of marital privacy to justify giving wife

129. 1 Miss. (1 Walker) 156 (1824). There is evidence that the legal status of chastisement was in doubt in Mississippi during the 1820s. The defendant in Bradley requested the circuit judge to instruct the jury that if they found that the victim was the defendant's wife, they could not find the defendant guilty of assault and battery; the circuit judge refused this request, and the defendant appealed this decision to the state's supreme court, which affirmed. See id. at 157; see also WYATT-BROWN, supra note 70, at 281-82 (noting growing social discomfiture with wife beating despite minimal legal recourse).

130. Bradley, 1 Miss. (1 Walker) at 158 (emphasis added).

131. Citing Blackstone and other authorities, the judge in Bradley invoked the doctrine of chastisement, which allowed husbands to use "a whip or rattan, no bigger than [their] thumb, in order to inforce the salutary restraints of domestic discipline." Id. at 157. Not surprisingly, a continuing commitment to authority-based conceptions of marriage undergirds the opinion, manifested in the court's concluding exhortation: "[L]et the husband be permitted to exercise the right of moderate chastisement, in cases of great emergency, and use salutary restraints in every case of misbehaviour, without being subjected to vexatious prosecutions, resulting in the mutual discredit and shame of all parties concerned." Id. at 158.

The claim that it would be unseemly to consider questions of domestic violence in a court of law makes an appearance in an 1838 Delaware case of a man fined for striking his pregnant wife; the defendant's counsel argued "that a husband had the right to chastise his wife; and it would not be politic to encourage these complaints in a court of justice, between persons bearing the relation of husband and wife." State v. Buckley, 2 Del. (2 Harr.) 552, 552 (1838) (emphasis added). In Buckley, the court allowed the prosecution, over the husband's objection that he had the right to chastise his wife, on the grounds that the chastisement administered in this case was excessive: "We know of no law that will authorize a husband to strike his pregnant wife a blow with his fist, such as has been inflicted on this woman.... [A]ny undue or excessive battery by a husband of his wife either in degree, or with improper means, [is] indictable." Id. (emphasis added).

When the North Carolina Supreme Court upheld the right of chastisement in the 1864 case of State v. Black, 60 N.C. (Win.) 262 (1864), the court justified the prerogative on two grounds: the husband's authority over his wife ("[a] husband is responsible for the acts of his wife, and he is required to govern his household," id.) and the need to shield domestic conflicts from public scrutiny ("the law will not invade the domestic forum or go behind the curtain," $i d$.). In Black, the traditional hierarchy-based rationale for chastisement law was intermingled with the new privacy-based rationale:

Certainly the exposure of a scene like that set out in this case can do no good. In respect to the parties, a public exhibition in the court-house of such quarrels and fights between man and wife widens the breach, makes reconciliation almost impossible, and encourages insubordination; and in respect to the public, it has a pernicious tendency; so, pro bono publico, such matters are excluded from the courts, unless there is a permanent injury or excessive violence or cruelty indicating malignity or vindictiveness.

Id. at 262 (emphasis added). 
beaters immunity from prosecution, much as he could invoke authority-based conceptions of marriage to justify giving husbands a formal prerogative to beat their wives. To quote a North Carolina chastisement opinion:

We know that a slap on the cheek, let it be as light as it may, indeed any touching of the person of another in a rude or angry manner-is in law an assault and battery. In the nature of things it cannot apply to persons in the marriage state, it would break down the great principle of mutual confidence and dependence; throw open the bedroom to the gaze of the public; and spread discord and misery, contention and strife, where peace and concord ought to reign. It must be remembered that rules of law are intended to act in all classes of society. ${ }^{132}$

Significantly, as this North Carolina case invokes privacy as a justification for chastisement, it mentions the cross-class applicability of the chastisement rule, as if to say, "remember, if we abolish the prerogative, this would authorize courts to inquire into marital violence "in all classes of society."

As courts addressed the regulation of marital violence in the wake of chastisement's demise, judges raised concerns about invading the privacy of the marriage relationship-most often, it would appear, when they contemplated the prospect of sanctioning wife beating in households of the middle and upper classes. From this standpoint, it is significant that when the Alabama Supreme Court justified its decision to allow prosecution of the emancipated slave accused of wife beating in Fulgham, it never raised the subject of marital privacy. As we will see, concerns of marital privacy were regularly raised by courts addressing the regulation of marital violence during the Reconstruction Era.

In the following sections I examine a group of criminal and tort cases that addressed the regulation of marital violence in the wake of chastisement's demise. These cases illustrate how courts reasoning within norms of companionate marriage could repudiate chastisement, and, at the same time, invoke concepts of privacy to justify giving wife beaters immunity from public and private prosecution. As this discussion will demonstrate, the repudiation of chastisement precipitated a shift in the rules and rhetoric of laws regulating interspousal violence-giving rise to a new doctrinal regime couched in discourses of affective privacy that preserved, to a significant degree, the marital prerogative that chastisement rules once protected. A review of the post-chastisement case law also suggests that judicial concerns about privacy were class-salient, invoked to protect propertied men from regulatory oversight in ways they were not invoked to protect the poor.

132. State v. Hussey, 44 N.C. (Busb.) 123, 126-27 (1852) (emphasis added) (holding wives incompetent to testify against husbands in all cases of assault and battery, except where permanent injury or great bodily harm is inflicted). 


\section{A. Marital Violence and Marital Privacy in the Criminal Law}

Just three years before the Alabama Supreme Court repudiated the doctrine of marital chastisement in Fulgham v. State, the North Carolina Supreme Court repudiated the prerogative in the 1868 case of State $v$. Rhodes. ${ }^{133}$ The Rhodes case is a frequently cited opinion which provides an interesting counterpoint to Fulgham. In Rhodes, the North Carolina Supreme Court repudiated chastisement doctrine yet declined to enforce an assault and battery charge against a man who assaulted his wife, instead granting him a limited immunity from criminal prosecution in an opinion couched in the rhetoric of affective privacy.

In Rhodes, the defendant whipped his wife "three licks, with a switch about the size of one of his fingers (but not as large as a man's thumb)", ${ }^{134}$ the trial court ruled that a husband had the right to chastise his wife and so was not guilty of assault and battery. On appeal, the North Carolina Supreme Court upheld the verdict but justified it on different grounds. Opening its opinion with the blunt observation that "[t]he violence complained of would without question have constituted a battery if the subject of it had not been the defendant's wife," ${ }^{135}$ the court explained why it would not find the defendant guilty:

The courts have been loth to take cognizance of trivial complaints arising out of the domestic relations-such as master and apprentice, teacher and pupil, parent and child, husband and wife. Not because those relations are not subject to law, but because the evil of publicity would be greater than the evil involved in the trifles complained of; and because they ought to be left to family government. ${ }^{136}$

The Rhodes opinion is striking because it reveals the extent to which concerns about "the evil of publicity" that might result from enforcing criminal law in the family in turn rest upon traditional patriarchal assumptions about "family government"-an institution that this court asserted was "recognized by law as being as complete in itself as the State government is in itself, and yet subordinate to it."137 Given the court's continuing commitment to traditional authority-based conceptions of marriage, we might restate the privacy rationale it offered as follows: "[T]rivial complaints arising out of the domestic relations" are touchings "subject to law" which this court might adjudicate; yet the court declines to exercise its jurisdiction to do so, because "the evil of publicity" to the master of the household "would be greater than

133. 61 N.C. (Phil. Law) 453 (1868).

134. Id. at 454 .

135. Id.

136. Id. (emphasis added).

137. Id. at 456 . 
the evil involved in the trifles complained of" by the wife. In short, judicial involvement in adjudicating complaints arising from the internal affairs of the household was injurious because it encroached upon the authority of its master.

Yet the Rhodes opinion never directly invokes the authority of a master. Instead, the opinion explores these questions of jurisdiction and authority through the discourse of affective privacy:

[H]owever great are the evils of ill temper, quarrels, and even personal conflicts inflicting only temporary pain, they are not comparable with the evils which would result from raising the curtain, and exposing to public curiosity and criticism, the nursery and the bed chamber. Every household has and must have, a government of its own, modelled to suit the temper, disposition and condition of its inmates. Mere ebullitions of passion, impulsive violence, and temporary pain, affection will soon forget and forgive; and each member will find excuse for the other in his own frailties. But when trifles are taken hold of by the public, and the parties are exposed and disgraced, and each endeavors to justify himself or herself by criminating the other, that which ought to be forgotten in a day, will be remembered for life. ${ }^{138}$

The claim that "[e]very household has and must have, a government of its own" is the only traditional juridical proposition in this passage; but the claims about the psychodynamics of family life in which it is embedded are also juridical propositions, claims about the administration of justice expressed in the language of privacy and affect. The court reaches its decision to abstain from exercising its jurisdiction to adjudicate the conflict by weighing the emotional consequences of intervening in the conflict for the husband and the wife, in a framework that tacitly incorporates their relative privileges and disabilities under the marital status rules of the common law. The court never expressly invokes these common law privileges and disabilities; instead, like the prescriptive literature of the era we have examined, ${ }^{139}$ the opinion discusses questions of authority and submission in the affect-based discourses of companionate marriage.

We can even read the Rhodes opinion as translating the old common law of chastisement into the discourse of companionate marriage. When the court announces that "[m]ere ebullitions of passion, impulsive violence, and temporary pain, affection will soon forget and forgive," it is asserting that an affectionate wife has the reserves of altruism to forgive her husband's outbursts of violence; from a common law baseline, a wife is expected to submit. (Recall William Alcott's assertion that "the balance of concession" in marital conflicts would fall to the wife, and his counsel that "the more cheerful and voluntary

138. Id. at 457.

139. See supra text accompanying notes 103-13. 
the submission, the happier the results. ... Perhaps there is no one thing on which domestic happiness so much depends as this ...."140) From this standpoint, it is hardly surprising that the court judges the "evils" a wife might suffer in having no legal protection from assault minor in comparison to the loss of authority a husband might suffer in having a court review and sanction his assertion of prerogative. For this is the sense of the court's claim that "when trifles are taken hold of by the public, and the parties are exposed and disgraced, and each endeavors to justify himself or herself by criminating the other, that which ought to be forgotten in a day, will be remembered for life." The husband's loss of authority is twofold: He is "exposed" and "disgraced" by public review of his assertion of prerogative over a member of his household, and his wife is encouraged to resent and defy, rather than submit to, his authority (she will "remember" rather than "forget" his violent outburst). ${ }^{141}$ Thus, reasoning from common law premises, the court concludes that it is easier for an altruistic wife to forgive her husband's impulsive violence than it is for a husband to suffer the loss of authority entailed in having his exercise of prerogative reviewed by public authorities. The court's conclusion makes sense, either as a claim about psychology (in which the gravity of emotional injury is weighed in light of social expectations engendered by the common law) or as a claim about marital status law (in which status prerogatives and disabilities are expressed in a new legal idiom drawn from the discourse of companionate marriage).

Yet if the common law of marital status visibly shapes the Rhodes opinion, it is important to note how carefully the court distances itself from the very tradition on which it draws. The court dislocates the various feelings it discusses from the (gendered) persons who might bear them-endeavoring quite self-consciously to disassociate itself from a common law tradition that assigns prerogatives and disabilities to "husband" and "wife" on a genderspecific basis. As the common law of chastisement is translated into the conceptual framework of companionate marriage, it undergoes a change both in rhetoric and in rule structure. For unlike the privacy-based chastisement opinions examined in the introduction to this part, the Rhodes opinion was repudiating chastisement doctrine, not offering a supplemental justification for it. The North Carolina Supreme Court was quite explicit about this:

[T] he ground upon which we have put this decision, is not, that the husband has the right to whip his wife much or little; but that we will

140. ALCOTT, supra note 104 , at 30-31.

141. Cf. State v. Black, 60 N.C. (Win.) 262, 262 (1864):

In respect to the parties, a public exhibition in the court-house of such quarrels and fights between man and wife widens the breach, makes reconciliation almost impossible, and encourages insubordination; and in respect to the public, it has a pernicious tendency; so, pro bono publico, such matters are excluded from the courts, unless there is a permanent injury or excessive violence or cruelty indicating malignity or vindictiveness. 
not interfere with family government in trifling cases. We will no more interfere where the husband whips the wife, than where the wife whips the husband; and yet we would hardly be supposed to hold, that a wife has a right to whip her husband. We will not inflict upon society the greater evil of raising the curtain upon domestic privacy, to punish the lesser evil of trifling violence. ${ }^{142}$

The court supplanted a husband's prerogative to chastise his wife with a limited immunity from prosecution that happened to coincide with his former right to give his wife "moderate correction."143 A gender-specific prerogative once justified in the language of hierarchy now appears as a "gender-neutral" immunity justified in the language of affect and privacy. (Note how in this context, the language of gender neutrality is privilege-protecting.)

Just as the gender-based preoccupations of the Rhodes opinion are selfconsciously submerged in formally gender-neutral rules, the class-based preoccupations of the Rhodes opinion are also submerged in formally classneutral rules. When the court discusses the "evils" of interfering with "family government," it is most concerned with protecting the authority/privacy of middle-class and upper-class men, as the opinion makes clear in a secondary rationale for the immunity rule it adopts. As an additional justification for its refusal to apply the criminal law to wife beating, the court asked how a judge was to "weigh the provocation in every trifling family broil":

Suppose a case coming up to us from a hovel, where neither delicacy of sentiment nor refinement of manners is appreciated or known. The parties themselves would be amazed, if they were to be held responsible for rudeness or trifling violence. What do they care for insults and indignities? In such cases what end would be gained by investigation or punishment? Take a case from the middle class, where modesty and purity have their abode but nevertheless have not immunity from the frailties of nature, and are sometimes moved by the mysteries of passion. What could be more harassing to them, or injurious to society, than to draw a crowd around their seclusion. Or take a case from the higher ranks, where education and culture have so refined nature, that a look cuts like a knife, and a word strikes like a hammer... where an indignity is disgrace and exposure is ruin. Bring all these cases into court side by side, with the same offence charged and the same proof made; and what conceivable charge of the court to the jury would be alike appropriate to all the cases, except,

142. Rhodes, 61 N.C. (Phil. Law) at 459 (emphasis added).

143. The North Carolina Supreme Court reiterated this analysis of the criminal law governing assault and battery in marriage in State v. Edens, 95 N.C. 693, 696 (1886) (finding husband not indictable for slandering his wife). 
That they all have domestic government ... suited to their own peculiar conditions, and that those governments are supreme, and from them there is no appeal except in cases of great importance requiring the strong arm of the law, and that to those governments they must submit themselves. ${ }^{144}$

For this court at least, judicial respect for privacy was responsive to the needs of the "middle class" and those of "the higher ranks" for whom "an indignity is disgrace and exposure is ruin." 145 Yet the court announced its decision to provide wife beaters a limited immunity from criminal prosecution without expressly linking it to the class status of the accused. Thus, both the class and gender referents of the norms supporting the new policy were suppressed as it was codified into rule form. As the court summed up the new doctrine six years later in a much-quoted opinion: "If no permanent injury has been inflicted, nor malice, cruelty nor dangerous violence shown by the husband, it is better to draw the curtain, shut out the public gaze, and leave the parties to forget and forgive."146

These North Carolina cases repudiate chastisement, yet carry forward its concerns within discourses of affective privacy. By now it should be clear enough how privacy talk was deployed in the domestic violence context to enforce and preserve authority relations between man and wife. But the significance of privacy talk in regulating authority relations among men bears further consideration.

Note how the Rhodes court draws a linkage between class and sensibility, and then between sensibility and the need for privacy. ("Rudeness" is common in cases arising from the hovels, "where neither delicacy of sentiment nor refinement of manners is appreciated or known"; by contrast, persons of the middle and upper classes are characterized by "modesty and purity"-for them, "an indignity is disgrace and exposure is ruin.") This correlation between sensibility and class was commonplace in the nineteenth century; we have already observed it in the context of cruelty doctrines in divorce law. ${ }^{147} \mathrm{~A}$ recent account of nineteenth-century etiquette manuals sheds further light on the tacitly class-based understandings of the discourse of affective privacy. In

144. Rhodes, 61 N.C. (Phil. Law) at 458-59 (emphasis added).

145. See supra text accompanying note 132 (quoting State v. Hussey, 44 N.C. (Busb.) 123, 126-27 (1852)).

146. State v. Oliver, 70 N.C. $60,61-62$ (1874) (emphasis added).

147. As we have seen in the divorce context, claims about marital cruelty were articulated in a similarly class-conscious manner. See supra notes 56-61 and accompanying text. See generally Griswold, Mental Cruelty, supra note 58, at 133-34:

By the last decades of the nineteenth century, neurasthenia had become part of the modern medical landscape, a symbol of civilization and a perverse badge of respectability among the middle class. . . . Thus, claims to happiness and complaints of cruelty had to be judged in light of the character and class of the individuals engaged in the suit. 
Rudeness \& Civility: Manners in Nineteenth-Century Urban America, historian John Kasson argues that in the nineteenth century

[a] new kind of embarrassment and sense of shame emerged ... one that fed upon uncertainties of status, of belonging, of living up to often ambiguous standards of social performance in a society in which all claims of rank were subject to challenge. The intense bourgeois concern with "rudeness" in the nineteenth century must be viewed in relation to this altered context of shame and embarrassment. Rudeness in this culture constituted a kind of social obscenity, a violation of the codes of civility in such a way as to make public that which should remain private, to single out for special attention that which should remain inconspicuous, or else to cast public actions, conduct, and individual actors in an unworthy or degrading light. ${ }^{148}$

Kasson remarks dryly that "[m]anners provided yet another way of avoiding talking openly about the dirty secret of class in America."149

Kasson's account of nineteenth-century etiquette manuals sheds interesting light on the adjudication of wife-beating claims as it analyzes how an individual's public demeanor was important in laying claim to social status. Etiquette manuals coached their readers on the acquisition of such demeanor, exhorting self-control as the path to privileged bearing. "Command yourself,' The Illustrated Manners Book enjoined its male readers in 1855. . . . 'The first element of a gentlemanly dignity is self-control. ..."150 Etiquette writers were most concerned with "[s]hows of anger," a topic that generated a large body of commentary in which "questions of gender and status quickly came into play."151 Men of the privileged classes were thus obliged to control anger and many other feelings to establish their claim to social status. A popular etiquette manual explained in 1871: "As we look, so we feel, so we act, and so we are. But we may direct and control even our thoughts, our

148. JOHN F. KASSON, RUDENESS \& CIVILITY: MANNERS IN NINETEENTH-CENTURY URBAN AMERICA 115 (1990) (footnote omitted).

149. Id. at 67; see id. at 62 ("[A]postles of civility battled for far bigger stakes than how best to eat asparagus. ... Seeking to avoid overt conflict [in a rapidly industrializing democracy], they turned issues of class and social grievance back upon the individual. They redefined issues of social conflict to questions of personal governance, social propriety, and 'good taste.'").

150. Id. at 148 (quoting ROBERT DE VALCOURT, THE ILlustrated MANNERs BOOK: A MANUAL of GOOD BEHAVIOR AND POLITE ACCOMPLISHMENTS 205 (New York, Leland, Clay 1855)).

151. Id. at 157; see also id. at 157-61. Popular fiction of the era also emphasized the necessity of controlling anger, especially in the domestic context. See CAROL ZISOWITZ STEARNS \& PETER N. STEARNS, ANGER: THE STRUGGLE FOR EMOTIONAL CONTROL IN AMERICA's HISTORY (1986):

[R] eaders of domestic tales were constantly advised that angry people were people of bad character and therefore could be viewed as alien or different from oneself. ... The "bad character" approach led to popular stories and even scientific accounts, well into the twentieth century, that stressed the distinctive physical features of angry people-red faced, with swollen veins, trembling - because these features denoted the destructiveness of angry behavior and its otherness, its location not in people in general but in bad people.

Id. at 45 (footnote omitted). 
feelings, and our acts, and thus, to some extent-by the aid of grace-become what we will." 152 Kasson argues that the etiquette manuals taught civility rules in such a way as to naturalize class status as the product of individual character and sensibility. ${ }^{153}$

From this standpoint, it is easier to understand how the values of privacy Rhodes articulates implicate questions of status and authority, not only between men and women (the domain of "family government"), but among men as well. Adjudicating wife-beating claims in a court of law would reveal that middle- and upper-class men "have not immunity from the frailties of nature, and are sometimes moved by the mysteries of passion," and, as the Rhodes court points out, "[w] $[\mathrm{wat}$ could be more harassing to them, or injurious to society, than to draw a crowd around their seclusion." 154 In short, the adjudication of wife-beating claims among men of the privileged classes would subject their demeanor and bearing to social scrutiny in ways that might call into question their claim to social authority-as it would not men of the poorer classes. It is only for the "refined," after all, that "an indignity is disgrace and exposure is ruin." 155

With these matters of privacy and class in mind, it is worth recalling that when the Alabama Supreme Court justified prosecuting the emancipated slave who had beaten his wife in Fulgham v. State, it reasoned about the question in the discourse of companionate marriage without ever mentioning considerations of marital privacy. In this context, we might also recall the latenineteenth-century campaign to reinstate the whipping post as a punishment for wife beating; penologists who advocated the whipping post as a method of breaking men of the so-called "vicious classes" recommended the technique at least in part because it entailed a public shaming. As the chief justice of Delaware touted the virtues of his state's whipping post: "'The sting is in the public disgrace and ignominy of the whipping, and in this line lies its efficiency." 156 Or, as the Reverend Phebe Hanaford put it: "The news of the

152. SAmUel R. Wells, New Physiognomy, or, Signs of Character at iii (New York, American Book Co. 1871), quoted in KASSON, supra note 148, at 149.

153. See KASSON, supra note 148, at 198:

[B]ecause such tastes and practices are so habitual and because they are literally embodied in the individuals who share them, they take on the character of natural categories. It becomes easy for the socially privileged to regard their class position and prestige as the product of their natural attributes, including their superior "taste" and "breeding," rather than the cause, and for those lower on the social scale to accept their domination and to see the rich (in Scott Fitzgerald's famous phrase) as "different from you and me," set apart by nature rather than class and culture.

154. State v. Rhodes, 61 N.C. (Phil. Law) 453, 458 (1868).

155. Id.

156. Bell, Wife Beaters, supra note 76, at 168 (quoting Charles B. Lore, chief justice of Delaware) (emphasis added). 
punishment will speedily become public property, whether the whipping-post be in sight of all men or not. There is little chance of privacy or concealment in the white light or the lurid glare of the Nineteenth Century press."157 If privacy discourses of the sort invoked in Rhodes did not play a major role in the criminal prosecution of wife beating in the late nineteenth century, it is because criminal prosecution of wife beaters during this era was focused on controlling men of the "lower classes"158 -men whose privacy needs elites scarcely acknowledged, much less sought to protect. Indeed, given the classbased concerns informing Rhodes's injunction against "raising the curtain, and exposing to public curiosity and criticism, the nursery and the bed chamber"159 - we might even speculate that criminal prosecution of wife beaters during the late nineteenth century served at least in part to construct "the vicious classes" as vicious and rude, and thus to justify distinctions of authority and status among men.

To appreciate how the discourse of affective privacy protected the authority of privileged men, as against their wives as well as men of the lower classes, it is helpful to examine the development of tort law concerning marital violence during the Reconstruction Era. As we will see, privacy-based reasoning about marital violence played a key role in the law of intentional torts as it emerged from reform by the married women's property acts. It was in the law of torts that privacy-based reasoning about marital violence flourished, before returning to shape the criminal law during the early twentieth century.

\section{B. Affective Privacy in the Emerging Law of Interspousal Tort Immunity}

While it was clear by the second half of the nineteenth century that wife beating was a crime, it was not at all clear that this same conduct constituted a tort. A criminal prosecution for wife beating was brought against a husband by the state, while a tort claim was prosecuted by the married woman herself. Could a battered wife bring suit against her husband in order to vindicate her own injuries without depending upon the state to intervene and protect her? The question was startling to those versed in common law understandings of marriage. The same body of common law that vested a husband with the prerogative to chastise his wife also denied married woman the right to file

157. Hanaford, supra note 79, at 110; see id. at 109.

158. See supra notes 81-89 and accompanying text.

159. Rhodes, 61 N.C. (Phil. Law) at 457. 
suit without her husband's consent and joinder. ${ }^{160}$ Interspousal litigation violated fundamental precepts of the doctrine of marital unity.

But if the prospect of a wife suing her husband contravened the most basic common law concepts of marriage, it was also an inevitable outgrowth of common law reform in the mid-nineteenth century-a period when the doctrine of marital unity was undergoing statutory modification under the pressure of feminist advocacy. Courts asked to determine whether wife beating was a tort had to interpret the married women's property acts whose enactment the woman's rights movement had advocated. Among the many rights these laws gave married women was the right to file suit without their husbands' joinder, and the right to collect tort damages for injuries to their persons and property. ${ }^{161}$ Under these reform statutes, could a wife now bring a tort suit against a husband who assaulted her and collect money damages? The question presented women as agents of their own vindication in a dual sense: A plaintiff sought redress for her injury without relying on the state to protect her, and she did so under the authority of legislation enacted in response to feminist advocacy. ${ }^{162}$

The law of torts differed from the criminal law in one other respect relevant to our analysis of the development of modern domestic assault law. A wife was likely to bring suit for money damages against a husband who assaulted her only in circumstances where there were assets to redistribute within the family. Thus, as jurists would surely recognize, it was married men of the middle and upper classes who might face tort claims for wife

160. See JOSEPH STORY, COMMENTARIES ON EQUITY PLEAdINGS, AND THE INCIDENTS THEREOF, ACCORDING TO THE PRACTICE OF THE COURTS OF EQUITY, OF ENGLAND AND AMERICA 54-55 (Boston, Little, Brown \& Co. 7th ed. 1865) (1857):

[A] feme covert cannot, at law, sue except jointly with her husband; for she is deemed to be under the protection of her husband; and a suit respecting her rights or interests must be with the assent and coöperation of her husband. The rule in suits in equity is, in ordinary cases, the same as at law; and the husband must join in the suit.

Id. (citations omitted). But see id. at 56-58 \& n.3 (discussing exceptions at equity allowing wife to maintain suit against her husband under name of male third party respecting her separate property or other rights secured by settlement).

161. See, e.g., infra notes 164,177 and accompanying text (quoting New York and District of Columbia statutes).

162. Single women suffering sexual assault in this era generally lacked remedies in tort. See Lea VanderVelde, The Ways of Seduction, 48 STAN. L. REv. 601 (1996) (tracing various common law doctrines that precluded single women from bringing tort suits in cases of sexual assault and analyzing enactment of laws in Reconstruction Era that gave women standing to sue). As VanderVelde notes, only one nineteenth-century woman's rights activist seems to have addressed the problem. See CAROLINE HEALEY DALL, Woman's Rights Under the Law, in THREE LECTURES DELIVERED IN BOSTON, JANUARY, 1861, at 43 (Boston, Walker, Wise \& Co. 1861) ("No single woman, having been seduced, has any remedy at common law; neither has her mother nor next friend. If her father can prove service rendered, he may sue for loss of service."), quoted in VanderVelde, supra, at 674 n.356. Reform of the common law seems to have occurred quietly, through code pleading reform rather than political activism of the sort that prompted passage of the married women's property acts. See VanderVelde, supra, at 673 ("With almost no public pressure and little public recognition of a need for reform of [the writ of seduction], the Field codes specifically advocated the ability of women to sue in their own rights and recover damages for seduction."). 
beating-precisely those men who were unlikely to face criminal prosecution for wife beating during the late nineteenth century.

With these gender- and class-salient features to recommend it, the new tort claim was not well received. Regardless of whether a husband beat, choked, stabbed, or shot his wife, all courts reviewing such claims initially rejected them, reasoning that spouses could not sue each other in tort-and buttressing this conclusion with justifications couched in the language of affect and privacy. (This doctrine of "interspousal tort immunity" survived well into the twentieth century, and today still bars claims of intentional torts, either in whole or in part, in nearly a fifth of the states. ${ }^{163}$ )

New York courts were the first to face the question. In 1860, New York enacted a nationally renowned statute giving a married woman the right to her earnings and the capacity to sue in contract and tort, including the right to "bring .... an action in her own name, for damages, against any person or

163. See Carl Tobias, Interspousal Tort Immunity in America, 23 GA. L. REV. 359, 383 (1989) ("Between 1863 and 1913, judges unanimously rejected interspousal personal injury claims. . . From 1914 until 1920, jurists in seven states allowed such actions, and a comparable number denied them. During the ensuing half century, immunity slowly eroded.").

Today, the doctrine of interspousal tort immunity still bars claims of intentional torts, either in whole or in part, in nine states. Interspousal immunity doctrine has been abrogated in 41 states. See, e.g., Shook v. Crabb, 281 N.W.2d 616, 619 (Iowa 1979) ("While the state has an interest in encouraging marital harmony, to deny a forum for the redress of a wrong would do little to advance the compatibility of a married couple. It is difficult to see how denying access to the legal process could be said with any certainty to encourage domestic tranquillity."); Burns v. Burns, 518 So. 2d 1205, 1210 (Miss. 1988) ("The idea that maintenance of interspousal immunity will promote the public interest in domestic tranquillity is wholly illusory. If one spouse commits against the other an act which, but for the immunity, would constitute a tort, the desired state of matrimonial tranquility is necessarily destroyed."); see also Klein v. Klein, 376 P.2d 70 (Cal. 1962); State Farm Mut. Auto Ins. Co. v. Westlake, 324 N.E.2d 137, 139 (N.Y. 1974). Given that many states have abrogated the tort immunity doctrine quite recently, it remains to be seen how the legacy of the immunity rule will shape the law of interspousal torts. For example, in the course of abrogating the immunity rule, the Missouri Supreme Court dismissed concerns that "removal of the bar will lead to a rash of claims of the "unwanted kiss' and 'rolling pin' variety." The court pointed out that such conduct (which it defined as "minor physical abuse, possibly constituting trivial torts") could be handled by courts on a "case-by-case basis" by "adjust[ing] the duty of care required between married persons to accommodate the 'give-and-take' of married life." S.A.V. v. K.G.V., 708 S.W.2d 651, 653 \& n.3 (Mo. 1986).

One state, Georgia, has determined that the question of interspousal tort immunity should be abrogated where there is no marital harmony to be protected by application of the immunity rule. See Smith v. Rowell, 335 S.E.2d 461 (Ga. 1985); Harris v. Harris, 313 S.E.2d 88 (Ga. 1984).

One state, Utah, has abrogated the interspousal immunity doctrine with respect to intentional torts only. See Stoker v. Stoker, 616 P.2d 590 (Utah 1980).

Six other states have abrogated the doctrine, in whole or in part, as to negligent torts only. See, e.g., Lewis v. Lewis, 351 N.E.2d 526, 532 (Mass. 1976) ("Conduct, tortious between two strangers, may not be tortious between spouses because of the mutual concessions implied in the marital relationship. For this reason we limit our holding today to claims arising out of motor vehicle accidents.").

Two states still retain the doctrine of interspousal tort immunity in its entirety. See Raisen v. Raisen, 379 So.2d 352, 354 (Fla. 1979) (interspousal tort actions "disturb domestic tranquility; cause marital discord and divorce"); Smith v. Southern Farm Bureau Casualty Ins. Co., 174 So. 2d 122, 124 (La. 1965) ("This immunity exists, commendably, to maintain domestic tranquility and promote the stability of the family unit.").

For an inventory of state positions on interspousal tort immunity as of November 1995, see LEONARD KARP \& ChERYL L. KARP, DOMESTIC TORTS: FAMILY VIOLENCE, CONFLICT AND SEXUAL ABUSE app. B at 383-85 (Supp. 1996). 
body corporate, for any injury to her person or character, the same as if she were sole." 164 Several years later, when a married woman brought suit against her husband for assault and battery, the New York Supreme Court interpreted the 1860 statute to bar her claim. While the trial court found that "the defendant assaulted and beat the plaintiff to her damage one hundred dollars," 165 the reviewing court reversed this verdict on appeal. The court acknowledged that the wife's right to sue her husband for assault and battery "may perhaps be covered under the literal language of [the statute]" but complained that this could not be "the meaning and intent of the legislature, and ... should not be the construction given to the act."166

The effect of giving so broad a construction to the act of 1860 , might be to involve the husband and wife in perpetual controversy and litigation-to sow the seeds of perpetual domestic discord and broil-to produce the most discordant and conflicting interest of property between them, and to offer a bounty or temptation to the wife to seek encroachment upon her husband's property, which would not only be at war with domestic peace, but deprive her probably of those testamentary dispositions by the husband, in her favor, which he would otherwise be likely to make. ${ }^{167}$

The court first reasoned that permitting a wife to sue her husband in tort would provoke marital conflict-presumably by allowing a married woman to assert herself in ways she could not at common law. (Recall the connection William Alcott drew between wifely submission and marital happiness: "Perhaps there is no one thing on which domestic happiness depends as this." ${ }^{\text {"68) }}$ ) After suggesting that recognizing the wife's claim would have adverse affective consequences for the relationship, the court then adverted to its adverse distributive consequences for the husband-quickly translating these distributive concerns into a rationale couched in the altruistic discourse of companionate marriage. It would be wrong for a court to grant a wife who had been beaten by her husband a damages claim in the husband's property because such an award might discourage the husband from demonstrating his testamentary generosity to his wife. ${ }^{169}$ (The court was deciding a matter of

164. 1860 N.Y. Laws, ch. $90, \$ 7$ (1860) (" $[$ A $]$ nd the money received upon the settlement of any such action or recovered upon a judgment, shall be her sole and separate property."); see also BASCH, supra note 17 , at $164,194-95$ (discussing enactment of 1860 statute).

165. Longendyke v. Longendyke, 44 Barb. 366, 366-67 (N.Y. Sup. Ct. 1863).

166. Id. at 368.

167. Id. at 369.

168. See supra text accompanying note 104.

169. Note that the plaintiff in this case was married for 30 years. Under the doctrine of marital service, her husband had property rights in the value of her labor for the entirety of this period, and, given judicial construction of the 1860 statute, most likely for the remainder of their married life as well. See Siegel, Modernization, supra note 38 , at 2149-68. 
first impression, a circumstance that might account for this last "stretcher" of an argument.)

This New York case was the first of a string of decisions granting a husband immunity from tort claims that his wife might bring against him. ${ }^{170}$ As we will see, its assertion that such litigation would "sow the seeds of perpetual domestic discord," coupled with the privacy-based rationale for criminal immunity developed by the North Carolina courts, emerged as standard rationales for the emergent doctrine of interspousal tort immunity.

The Supreme Court of Maine was one of the first to synthesize the "domestic harmony" and "privacy" rationales in a tort case decided in 1877. In Abbott v. Abbott, ${ }^{171}$ a woman sued her ex-husband in tort, alleging that he violently assaulted her, and for malicious reasons had her forcibly abducted, put in irons, and incarcerated in a mental institution, where she was "imprisoned as an insane person for a long time against her will and to the great injury of her health and comfort."172 The Maine court ruled that the plaintiff could not recover tort damages from her ex-husband. The court acknowledged that "there has been for many years a gradual evolution of the law going on, for the amelioration of the married woman's condition, until it is now, undoubtedly, the law of England and of all the American states that the husband has no right to strike his wife, to punish her, under any circumstances or provocation whatever." ${ }^{173}$ Yet, after repudiating the right of chastisement, the court declared that a husband was immune from tort liability for assaulting his wife. To support this view, the court quoted an opinion of the North Carolina Supreme Court explaining why a husband should be immune from criminal prosecution for beating his wife: "'it is better to draw the curtain, shut out the public gaze, and leave the parties to forget and forgive." 174 Asserting that a tort remedy was not "desirable" as a wife could seek relief in the criminal courts, or seek a divorce on grounds of cruelty, the court observed that "[i]t would be a poor policy for the law to grant the remedy asked for in this case," for "[t]he private matters of the whole period of married existence might be exposed by suits" and "this would add a new method by which estates could be plundered."175

When the United States Supreme Court construed the District of Columbia's married women's property act in 1910, it invoked both a "privacy" and a "domestic harmony" rationale for interspousal tort immunity. ${ }^{176}$ The Court asserted that Congress had not intended to give spouses the capacity to

170. For an exceptionally close reading of the New York cases, see F.A. Erwin, Assault and Battery (Wife vs. Husband), 3 UNIV. L. REV. 67 (1897).

171. 67 Me. 304 (1877).

172. Id. at 304 .

173. Id. at 307.

174. Id. (quoting State v. Oliver, 70 N.C. $60,61-62$ (1874)) (emphasis added).

175. Id. at 308 (emphasis added).

176. Thompson v. Thompson, 218 U.S. 611 (1910). 
sue each other when it provided that " " $[\mathrm{m}]$ arried women shall have power ... to sue separately ... for torts committed against them, as fully and freely as if they were unmarried"'; 177 it then observed that allowing intramarital suits would "open the doors of the courts to accusations of all sorts of one spouse against the other, and bring into public notice complaints for assault, slander and libel," and questioned "[w] hether the exercise of such jurisdiction would be promotive of the public welfare and domestic harmony." 178 By the early twentieth century, numerous state supreme courts had barred wives from suing their husbands for intentional torts-typically on the grounds that "the tranquillity of family relations" would be "disturb[ed]"

by dragging into court for judicial investigation at the suit of a peevish, fault-finding husband, or at the suit of the nagging, illtempered wife, matters of no serious moment, which if permitted to slumber in the home closet would silently be forgiven or forgotten.... [T]he welfare of the home, the abiding place of domestic love and affection, the maintenance of which in all its sacredness, undisturbed by a public exposure of trivial family disagreements, is so essential to society, demands and requires that no new grounds for its disturbance or disruption by judicial proceedings be ingrafted on the law by rule of court not sanctioned or made necessary by express legislation. ${ }^{179}$

It is important to observe that courts developed the doctrine of interspousal tort immunity in response to the reform of the common law. As the common law was slowly modified by statute and judicial decision, courts had to explain anomalies in the law of marital status that simply did not exist before. At common law, a wife lacked capacity to sue anyone without her husband's consent and joinder, so her inability to sue her husband was hardly in need of explanation. But once a married woman was granted the right to sue in tort for injuries to property or person, courts had to decide whether she could sue her husband and, if not, to explain why not. All courts to face the claim initially ruled against it, with some explaining the emergent law of interspousal tort immunity by invoking the doctrine of marital unity. But because the doctrine of unity was itself under attack, courts sought new grounds on which to justify the immunity bar. "Privacy" supplied grounds on which to justify interspousal tort immunity - grounds that were seemingly independent of the increasingly

177. Id. at 615-16 (quoting District of Columbia Code, $\S 1155,31$ Stat. 1189, 1374 (1901)); see id. at 617. Justices Harlan, Holmes, and Hughes dissented. See id. at 619-24 (Harlan, J., dissenting).

178. Id. at 617-18.

179. Drake v. Drake, 177 N.W. 624, 625 (Minn. 1920) (emphasis added); see also Lillienkamp v. Rippetoe, 179 S.W. 628, 629 (Tenn. 1915) (stating that marriage reform legislation not intended "to empower a wife to bring an action against her husband for injuries to her person occurring during the coverture, thereby making public scandal of family discord, to the hurt of the reputation of husband and wife ... unless such purpose clearly appears by the express terms of the act"). 
discredited language of marital hierarchy. And so the discourse of marital status began to shift from the rhetoric of "marital unity" to the rhetoric of "privacy" and "domestic harmony." By 1914 the Supreme Court of Oklahoma disparagingly characterized the tort immunity cases as "in a great measure controlled by the common-law rule under which the entity of the wife was completely lost in the husband," but then approvingly noted that "the stronger of the more modern decisions" were "based upon public policy," with courts "reasoning that to [hear tort claims between spouses] would tend to invade the holy sanctity of the home and shatter the sacred relations between husband and wife." $" 180$

In fact, the same shift in discourses of marital status that appears in tort law concerning marital violence also appears in property and contract doctrines governing wives' rights to their earnings. As I have discussed elsewhere, when legislatures passed earnings statutes granting married women the capacity to contract and property rights in the value of their labor, wives began to bring contract claims against their husbands seeking compensation for household labor. ${ }^{181}$ Many courts dismissed such claims on the grounds that the husband owned the value of "a wife's work" by right of marriage, hence there was no consideration to support his promise to pay for it. But as courts struggled to explain why wives could now contract with third parties for their labor, yet still could not contract with their husbands, judges began to shy away from the discourse of property-in-persons and to rely instead on a discourse of altruism and affect. ${ }^{182}$ As in the interspousal tort cases, courts adjudicating interspousal contract claims characterized the marital relation as subsisting in a domain beyond law. For example, in 1889, in the oft-quoted decision of Miller v. Miller, ${ }^{183}$ the Iowa Supreme Court explained why a husband's promise to pay his wife for her labor was unenforceable:

The marital obligation of husband and wife in the interest of homes, both happy and useful, have a higher and stronger inducement than mere money consideration, and they are generally of a character that the judgments or processes of the courts cannot materially aid .... It is to be kept in mind that public policy is not against the payment of money, if it is done voluntarily; but the evil which the law anticipates arises from the enforcement of such a contract, which, if legal, should of course be enforceable.

180. Fiedeer v. Fiedeer, 140 P. 1022, 1023 (Okla. 1914) (allowing wife's tort suit against husband who shot her in head). For a similar review of the case law, see Steele v. Steele, 65 F. Supp. 329, 330 (D.D.C. 1946) (allowing wife to bring tort suit against ex-husband for assault that occurred before divorce was finalized).

181. See Siegel, Modernization, supra note 38, at 2181-96.

182. See id. at 2199-206.

183. 42 N.W. 641 (lowa 1889). 
Enforcing interspousal contracts required courts to determine whether their terms were performed or breached, and

[i]t needs no argument to show that such inquiries in public would strike at the very foundations of domestic life and happiness. Public policy dictates that the door of such inquiries shall be closed; that parties shall not contract in such a manner as to make such inquiries essential to their enforcement. What element could be introduced into a family that would tend more directly to breed discord than this contract? ? $^{184}$

Similarly, in 1910, the Kentucky Supreme Court asserted that an interspousal contract claim for services could not be enforced in a court of law:

It would be contrary to public policy to permit either [spouse] to make an enforceable contract with the other to perform such services as are ordinarily imposed upon them by the marital relations, and which should be the natural prompting of that love and affection which should always exist between husband and wife. ${ }^{185}$

Thus, judges seeking to explain the modified structure of marital status law increasingly drew upon gender concepts of the industrial era to depict the law of marriage in more contemporary and socially credible terms. Rather than represent marriage in the biblical discourse of "one flesh,"186 as a hierarchical relation that "merged" the wife into husband, courts instead discussed marriage as it was understood in nineteenth-century America: as a companionate relationship based on an affective bond that flourished best in a sphere separate from civil society. And, over the decades, the idiom of marital status law shifted, with tropes of interiority (describing feelings and spaces) progressively supplanting tropes of hierarchy. Judges even discussed the privacy of the marital relationship by invoking heavily curtained windows of the sort fashionable in the late nineteenth century: ${ }^{187}$ Reasoning in this

184. Id. at 642. The Iowa Supreme Court asserted that "[i]t is of the genius of our laws, as well as of our civilization, that matters pertaining so directly and exclusively to the home . . . are not to become matters of public concern or inquiry. This thought has vindication throughout our system of jurisprudence." Id.

185. Foxworthy v. Adams, 124 S.W. 381, 383 (Ky. 1910).

186. See Crowell v. Crowell, 105 S.E. 206, 210 (N.C. 1920) (allowing wife to sue husband for infecting her with venereal disease). In Crowell, the North Carolina Supreme Court indicated that the "true ground" for exempting a husband from liability to his wife "was because by the marriage she became his chattel"; "[t]he fanciful ground assigned for this doctrine . . . is stated by some of the old writers to be the words in Genesis ii, 23, 24: "And Adam said, "This is now bone of my bones, and flesh of my flesh," adding that a man and wife "shall be one flesh."' Id.

187. During the nineteenth century, the mechanization of textile production resulted in a dramatic decrease in the cost of fabrics, and middle-class Americans began to use fabrics in a variety of ways in decorating their homes. See KATHERINE C. GRIER, CULTURE AND COMFORT: PEOPLE, PARLORS, AND UPHOLSTERY, 1850-1900, at 237-61 (1988). "Between 1850 and 1900, decorative window draperies became an increasingly important element of parlor decor in ordinary homes." Id. at 237. The authors of 
idiom of interiority, a court would not hear a wife's suit for damages against a husband who assaulted her because public policy counseled that " it is better to draw the curtain, shut out the public gaze, and leave the parties to forget and forgive."'188 The transformation in the discourse of marital status was far-reaching in scope, affecting its rhetoric and rule structure. Once, the common law had vested a husband with the right to command his wife's obedience, by physical chastisement if necessary, and had vested him with property rights in the economic value of her "services," but now courts represented marriage as an affective relationship uniquely unsuited to regulation by law. ${ }^{189}$ With this shift to the discourse of affective privacy, a husband's marital prerogatives could be preserved in a new juridical form-as legal immunities.

Once courts ceased to rely on tropes of marital unity and began to discuss marriage in the discourse of affective privacy, they no longer had to explain the law of marriage as enforcing relations of hierarchy. Instead, courts could explain the law of marriage as preserving relations of altruism. As the North Carolina Supreme Court observed:

"[The law] drops the curtain upon scenes of domestic life, preferring not to take cognizance of what transpires within that circle, to the exposure of them in a public prosecution. It presumes that acts of wrong committed in passion will be followed by contrition and atonement in a cooler moment, and forgiveness will blot it out of memory."190

In short, it was no longer necessary to justify a husband's acts of abuse as the lawful prerogatives of a master. Rather, the state granted a husband immunity

interior-decorating guides offered a variety of reasons for curtaining windows. As Janet E. Ruutz-Rees, author of Home Decoration, explained in 1881: "So many delightful possibilities are concealed by a curtain; not to mention the skillful hiding of defects made feasible with such means, or the softening of angles and happy obliteration of comers." Id. The authors of Beautiful Homes noted in 1878 that curtains could protect residents from "sprying eyes, or ... the feeling of fear at imagining some outside spectator gazing into our apartments during the evening hours."' Id. at 245 (quoting interior-decorating guide of 1870s). Another decorator recommended using curtains to block out aspects of the "outer world" that inhabitants found distasteful. Id. (advising that "'[i]f the outer world does not happen to be agreeable in that particular locality, it is well to employ ingenious devices for shutting it out'"); see also KASSON, supra note 148, at 175 (describing how "the use of fabrics spread . . . until by the late nineteenth century some parlors became virtual cocoons of gentility. Families covered the floor with carpets, shrouded the windows with thick draperies, hung curtains called portières across the entrance, swathed center tables, mantel tops, and pianos with hangings and skirts ....").

188. Abbott v. Abbott, 67 Me. 304, 307 (1877) (quoting State v. Oliver, 70 N.C. 60, 61-62 (1874)); see also Miller v. Miller, 42 N.W. 641, 642 (Iowa 1889) (holding that court will not enforce husband's promise to compensate his wife because "[p]ublic policy dictates that the door of such inquires shall be closed").

189. See Note, Litigation Between Husband and Wife, 79 HARV. L. REV. 1650, 1655-59 (1966) (discussing judicial view that "family matters simply are not justiciable in the sense of being properly resolvable in a judicial forum" in wide range of legal contexts).

190. State v. Fulton, 63 S.E. 145, 145 (N.C. 1908) (quoting State v. Edens, 95 N.C. 693 (1886)) (upholding spousal tort immunity for slander). 
to abuse his wife in order to foster the altruistic ethos of the private realm. In this way, laws that protected relations of domination could be justified as promoting relations of love. The regulation of marital violence was thus translated into the language of companionate marriage prevailing during the industrial era. When the modernization of marital status discourse is analyzed from this vantage point, we can more fully appreciate the maxim Schouler's treatise offered to explain chastisement's demise: "The rule of love has superseded the rule of force."191

\section{A Brief Reprise: Marital Privacy in the Criminal Law of the Twentieth Century}

By the beginning of the twentieth century, this new mode of reasoning about marital violence traveled from tort law back into criminal law, and found institutional expression in the criminal justice system. During this period, cities began to establish special domestic relations courts staffed by social workers to handle complaints of marital violence; by the 1920s, most major cities had such courts. ${ }^{192}$ The family court system sought to decriminalize marital violence. The underlying theory of this special court system, a New York City judge explained, was that "'domestic trouble cases are not criminal in a legal sense." "193 Rather than punish those who assaulted their partners, the judges and social workers urged couples to reconcile, providing informal or formal counseling designed to preserve the relationship whenever possible. Battered wives were discouraged from filing criminal charges against their husbands, urged to accept responsibility for their role in provoking the violence, and encouraged to remain in the relationship and rebuild it rather than attempt to separate or divorce. ${ }^{194}$ The police adjusted their arrest procedures to accord with the new philosophy of the domestic relations courts, channeling family violence cases out of the criminal justice system and into counseling whenever possible. In this institutional framework, physical assault was not viewed as criminal conduct; instead it was viewed as an expression of emotions that needed to be adjusted and rechanneled into marriage.

The criminal justice system regulated marital violence in this "therapeutic" framework for much of the twentieth century. There was no formal immunity rule as in tort law, but the criminal justice system developed a set of formal

191. SCHOULER, supra note 98 , at 59 .

192. PLECK, DOMESTIC TYRANNY, supra note 33, at 136.

193. Id. at 137 (quoting Judge Bernhard Rabbino of the New York City court of domestic relations).

194. Id. at 136-42; see Pleck, Criminal Approaches, supra note 50, at 44-45:

By the early twentieth century, judges of family courts . . . came to view criminal prosecution and police-like methods as unprofessional and outmoded. They believed that social casework methods were more efficient, humane, and better suited to handing the complicated dynamics of abusing families. Ironically, the greater the scrutiny in the family character of domestic violence, the lower the interest in its criminal side. 
procedures for handling marital violence-which it justified in the discourse of affective privacy - that provided informal immunity for the conduct in many circumstances. In the 1960s, for example, the training bulletin of the International Association of Chiefs of Police offered the following instructions for handling "family disturbances":

For the most part these disputes are personal matters requiring no direct police action. However, an inquiry into the facts must be made to satisfy the originating complaint.... Once inside the home, the officer's sole purpose is to preserve the peace ... [a]ttempt to soothe feelings, pacify parties ... [s]uggest parties refer their problem to a church or a community agency. ... In dealing with family disputes the power of arrest should be exercised as a last resort. The officer should never create a police problem when there is only a family problem existing. ${ }^{195}$

Until the last decade, this set of instructions was quite typical of police procedure in American cities. For example, the Oakland Police Department's 1975 Training Bulletin on Techniques of Dispute Intervention asserted that

"[t]he police role in a dispute situation is more often that of a mediator and peacemaker than enforcer of the law.... [T]he possibility that ... arrest will only aggravate the dispute or create a serious danger for the arresting officers .... is most likely when a husband or father is arrested in his home .... Normally, officers should adhere to the policy that arrests shall be avoided ... but [when] one of the parties demands arrest, you should attempt to explain the ramifications of such action ... and encourage the parties to reason with each other."196

It was not until the late 1970 s that the contemporary women's rights movement mounted an effective challenge to this regime. Today, after numerous protest activities and law suits, there are shelters for battered women and their children, new arrest procedures for police departments across the country, and even federal legislation making gender-motivated assaults a civil rights violation. ${ }^{197}$ Yet, as this Article opens by observing, battering of

195. International ass'N OF Police ChiEfs, Training KeY No. 16, Handling Disturbance Calls 94-95 (1968-69), quoted in Sue E. Eisenberg \& Patricia L. Micklow, The Assaulted Wife: "Catch 22" Revisited, 3 WOMEN's RTS. L. REP. 138, 156 (1977) (omissions in original) (emphasis added).

196. DEL MARTIN, BATTERED WIves 93-94 (1976) (quoting Oakland Police Department's training bulletin) (emphasis added).

197. See, e.g., Violence Against Women Act, Pub. L. No. 103-322, 108 Stat. 1796 (1994) (codified at 42 U.S.C.A. $\$ 13981$ (West 1995)) (providing grants to help prevent sexual assault and to support battered women's shelters). See generally Developments in the Law-Legal Responses to Domestic Violence, 106 HARV. L. REV. 1498, 1528-51 (1993) [hereinafter Developments in the Law] (discussing new state and federal responses to domestic violence). 
women by husbands, ex-husbands, and lovers remains the single largest cause of injury to women in the United States today. ${ }^{198}$

Because statistics on domestic violence document chastisement's continuing legacy in a different narrative mode, it is worth considering the recent figures in a bit more detail. As of 1995, Justice Department statistics show that:

- About three-quarters of all lone-offender violence against women was perpetrated by an offender whom the victim knew. ${ }^{199}$

- In $29 \%$ of all violence against women by a lone offender, the perpetrator was a husband, ex-husband, boyfriend, or ex-boyfriend-an intimate. $^{200}$

- Female victims of violent incidents were more likely to be injured when the perpetrator was an intimate than when the assailant was a stranger. ${ }^{201}$

The gender asymmetry of violence between intimates remains dramatic. The Justice Department has estimated that $90 \%$ to $95 \%$ of domestic violence victims are women. ${ }^{202}$ Compared to men, women were about six times more likely to experience violence committed by an intimate. ${ }^{203}$ Female homicide victims were more than nine times more likely to have been killed by a husband, ex-husband, or boyfriend than male homicide victims were to have been killed by their wife, ex-wife, or girlfriend. In 1992 approximately $28 \%$ of female victims of homicide were known to have been killed by their husband, ex-husband, or boyfriend; in contrast, just over 3\% of male homicide victims were known to have been killed by their wife, ex-wife, or girlfriend. ${ }^{204}$ In considering these statistics, it should be kept in mind that they include assaults by women undertaken in self-defense. ${ }^{205}$

198. See supra text accompanying note 5 .

199. BuREau of Justice STATISTICS, U.S. DeP'T of Justice, Violence Against Women: ESTIMATES FROM THE REDESIGNED SURVEY I (1995) [hereinafter BUREAU OF JUSTICE STATISTICS].

200. Id.

201. Id.

202. Laws Mandating Reporting of Domestic Violence: Do They Promote Patient Well-Being, 273 JAMA 1781 (1995) [hereinafter Laws Mandating Reporting of Domestic Violence] (citing BUREAU OF JUSTICE STATISTICS, U.S. DEP'T OF JUSTICE, VIOLENCE BETWEEN INTIMATES (1994)).

203. BuREAU OF JUSTICE STATISTICS, supra note 199, at 1.

204. See id. at 4.

205. Cf. Council on Scientific Affairs, Am. Medical Ass'n, Violence Against Women: Relevance for Medical Practitioners, 267 JAMA 3184 (1992) [hereinafter Violence Against Women], which observes that while

some surveys suggest nearly equal participation rates (ie, that about as many women as men have perpetrated at least one act of aggression), there is no measure of acts that are undertaken in self-defense. In general, men perpetrate more aggressive actions against their female partners than women do against their male partners, and men perpetrate more severe actions and are more likely to perpetrate multiple aggressive actions against their partner during a single incident than are women against male partners.

Id. at 3185-86 (citations omitted). See generally ANGELA BROWNE, WHEN BATTERED WOMEN KILL (1987) (discussing women who killed their batterers); ANN JONES, NEXT TIME, SHE'LL BE DEAD: BATTERING \& HOW TO STOP IT (1994); ANN JONES, WOMEN WHO KILL (1980) (describing patterns that prevail when 
As the statistics on homicide of women by intimates suggest, assaults between intimates can involve significant amounts of violence. The Justice Department estimates that one-third of domestic violence attacks, if reported, would be classified as felony rapes, robberies, or aggravated assaults. The rest would be classified as simple assaults, though many of them involved " "bodily injury at least as serious as the injury inflicted in 90 percent of all robberies and aggravated assaults." ${ }^{206}$ And the American Medical Association's Council on Scientific Affairs reports that "[o]ver $80 \%$ of all assaults against spouses and ex-spouses result in injuries, compared with $54 \%$ of the victims of stranger violence; victims of marital violence also have the highest rates of internal injuries and unconsciousness."207 (In a 1985 survey of intact couples, nearly one of every eight husbands had carried out an act of physical aggression against his female partner. "Over one-third of these assaults involved severe aggression such as punching, kicking, choking, beating up, or using a knife or a gun." ${ }^{208}$ )

Finally, domestic violence remains widespread. The Journal of the American Medical Association reports that approximately four million women are believed to be battered every year by their partners, and estimates that at least one-fifth of all women will be physically assaulted by a partner or expartner during their lifetime. ${ }^{209}$ The 1985 National Family Violence Survey found that "154 out of every 1000 pregnant women were assaulted by their mates during the first four months of pregnancy, and 170 per 1000 women were assaulted during the fifth through the ninth months" of pregnancy. ${ }^{210}$ Women who are assaulted by their male partners are more likely to be repeatedly attacked, raped, injured, or killed than are women assaulted by other types of assailants. ${ }^{211}$

As these statistics suggest, marital violence persists, notwithstanding profound changes in the laws and mores of marriage since the turn of the century. And, despite the contemporary feminist movement's efforts to pierce the veil of privacy talk surrounding the practice, Americans still reason about

women kill their batterers); Joan Zorza, Women Rarely Batter Men Except When Abused Themselves, N.Y. TIMES, Feb. 17, 1994, at A22 (emphasizing importance of context in evaluating domestic violence statistics).

206. Joseph R. Biden, Domestic Violence: A Crime, Not a Quarrel, TRIAL, June 1993, at 56, 56 (quoting NATIONAL INST. OF JUSTICE, U.S. DEP'T OF JUSTICE, Civil PROTECTION ORders: LeGiSLATION, CURRENT COURT PRACTICE, AND ENFORCEMENT 4 (1990)).

207. Violence Against Women, supra note 205, at 3184, 3186.

208. Id. at 3185 .

209. Laws Mandating Reporting of Domestic Violence, supra note 202, at 1781 (reporting, also, that prevalence of domestic violence among patients in ambulatory care settings has been estimated to be between $20 \%$ and $30 \%$ ).

210. Violence Against Women, supra note 205, at 3186-87.

211. Angela Browne, Violence Against Women by Male Partners: Prevalence, Outcomes, and Policy Implications, 48 AM. PSYCHOLOGIST 1077, 1077 (1993); see also id. at 1078 (observing that rape by male partners seems to occur most frequently in relationships in which male partner practices other forms of physical aggression; reviewing recent studies of the correlation). 
marital violence in the discourse of affective privacy. O.J. Simpson invoked this tradition in 1989 when he shouted at police who had responded to his wife's call for help: “"The police have been out here eight times before, and now you're going to arrest me for this? This is a family matter. Why do you want to make a big deal out of it when we can handle it?'"'12 The discourse of affective privacy still finds expression in law-and not only in interspousal tort immunity doctrine, which still is in force in some states. ${ }^{213}$ For example, when the American Law Institute most recently revised the Model Penal Code provisions on rape, it acknowledged that "the historic basis" of the marital rape exemption "probably lies ... in the older conception of the wife as chattel," but still insisted on preserving the exemption:

The problem with abandoning the immunity in many ... situations is that the law of rape, if applied to spouses, would thrust the prospect of criminal sanctions into the ongoing process of adjustment in the marital relationship. ... Retaining the spousal exclusion avoids this unwarranted intrusion of the penal law into the life of the family. ${ }^{214}$

More recently, the Chief Justice of the United States invoked this discourse of the private when he objected to provisions in the new Violence Against Women Act ${ }^{215}$ that create a federal cause of action for gender-motivated violence. The bill's "broad definition of criminal conduct is so open-ended, and the new private right of action so sweeping," Chief Justice Rehnquist complained, "that the legislation could involve the federal courts in a whole host of domestic relations disputes."216

\section{CIVIL RIGHTS REFORM AND THE MODERNIZATION OF STATUS DISCOURSE}

The principle of the constitutionality of discrimination based on sex was slowly weakening during the last years under its old sponsor, the common law; it reached a critical point where even some courts thought it might die; but it weathered the change from ancient to

212. Josh Meyer, Police Records Detail 1989 Beating that Led to Charge: A Bloodied Nicole Simpson, Hiding in Bushes After 911 Call, Told Officers: "He's Going to Kill Me." Judge Overruled Prosecutors' Request that Simpson Serve Jail Time, L.A. TIMES, June 17, 1994, at A24 (emphasis added).

213. See supra note 163.

214. MODEL PENAL CODE $§ 213.1$ cmt. 8(c) (1980) (emphasis added); see Robin West, Equality Theory, Marital Rape, and the Promise of the Fourteenth Amendment, 42 FLA. L. REV. 45, 64 (1990) ("Proponents of the marital rape exemption typically assert that the state's important interest in promoting marital harmony and intimacy, or, alternatively, its interest in encouraging reconciliation of warring spouses, justifies the statute.").

215. Pub. L. No. 103-322, 108 Stat. 1796 (1994) (codified at 42 U.S.C.A. $\$ 13981$ (West 1995)).

216. William Rehnquist, Chief Justice's 1991 Year-End Report on the Federal Judiciary, THIRD BRANCH, Jan. 1992, at 1, 3 (emphasis added). For more extended discussion of the Violence Against Women Act, and Chief Justice Rehnquist's remarks in particular, see infra Section IV.C. 
modern nomenclature, and under its new sponsor, public policy, it has fully regained its old strength.

Blanche Crozier, Constitutionality of Discrimination Based on Sex (1935) ${ }^{217}$

In this case we are dealing with a principle or doctrine of law that has its origin in an archaic time, when a wife was more a servant than a companion and partner....

- . .

... Since that time the unity concept of marriage has in a large part given way to the partner concept whereby a married woman stands as an equal to her husband in the eyes of the law.

Troue v. Marker (Indiana 1969) ${ }^{218}$

Gender is a complexity whose totality is permanently deferred, never fully what it is at any given juncture in time.

Judith Butler, Gender Trouble (1990) ${ }^{219}$

In this Article I have attempted to demonstrate, by genealogical excavation, that some kinds of privacy talk are properly understood as modern expressions of the putatively discredited doctrine of marital unity. There is no necessary connection here, only a historically contingent one. But the connection is terribly important to observe for just that reason. Status talk is mutable, and remarkably adaptable: It will evolve as the rule structure of a status regime evolves. ${ }^{220}$ In the ensuing sections I reflect briefly on the significance of this observation for our understanding of civil rights reform, both historical and contemporary.

\section{A. Historical Perspectives}

Status regimes are not static, but dynamic-revitalized from time to time as they are reshaped by diverse political forces and draw on evolving social mores. For example, in the decades after the Civil War, a regime of racial status built on the law of chattel slavery evolved in rule structure and rhetoric into the form of American apartheid known as "Jim Crow." The law of de jure

217. Blanche Crozier, Constitutionality of Discrimination Based on Sex, 15 B.U. L. REv. 723, 748-49 (1935).

218. 252 N.E.2d 800, 803-04 (Ind. 1969).

219. JUDITH BUTLER, GENDER TROUBLE: FEMINISM AND THE SUBVERSION OF IDENTITY 16 (1990).

220. As I have observed in a recent study examining reform of the common law rules giving husbands property rights in their wives' labor:

The long history of the doctrine of marital service suggests that caste regimes do not survive by their rigidity, but instead through their malleability and adaptability. The law of marital status was able to survive premature news of its death in part because status discourse has this chameleon-like quality. In short, status talk is not always detectible as status talk. Frequently, it may disguise itself - even by masquerading in the language of love.

Siegel, Modernization, supra note 38, at 2210-11. 
segregation differed from chattel slavery in its constitutive rules (so that former slaves were subject to a different set of labor codes and restrictions on their civil liberties); ${ }^{221}$ it is less commonly observed that the law of de jure segregation also differed from chattel slavery, at least in part, in the rhetorics employed to justify its constitutive rules. During the aptly named "Reconstruction" era, overtly hierarchy-based justifications offered for chattel slavery began to give way to justifications for apartheid that drew upon racial discourses of the private. ${ }^{222}$ Thus, in Plessy v. Ferguson, the Supreme Court

221. See Leon F. Litwack, Been in THE Storm So Long: The AfTERMath of Slavery 366-71, 375 (1979) (discussing Black Codes); JULIE SAVILLE, THE WORK OF RECONSTRUCTION: FROM SLAVE TO WAGE LABOR IN SOUTH CAROLINA, 1860-1870 (1994); C. VANN WOODWARD, THE STRANGE CAREER OF JiM CROW 22-23 (3d rev. ed. 1974) (discussing transition in regimes). See generally William Cohen, Negro Involuntary Servitude in the South, 1865-1940: A Preliminary Analysis, 42 J.S. HIST. 31 (1976) (discussing emergence of peonage, sharecropping, and particulars of labor abuses).

222. For example, in 1867, when the Pennsylvania Supreme Court ruled that a railroad could segregate its passengers by race, it asserted:

The natural separation of the races is . . . an undeniable fact, and all social organizations which lead to their amalgamation are repugnant to the law of nature. From social amalgamation it is but a step to illicit intercourse, and but another to intermarriage. But to assert separateness is not to declare inferiority in either; it is not to declare one a slave and the other $a$ freeman-that would be to draw the illogical sequence of inferiority from difference only. ... When, therefore, we declare a right to maintain separate relations, as far as is reasonably practicable, but in a spirit of kindness and charity, and with due regard to equality of rights, it is not prejudice, nor caste, nor injustice of any kind, but simply to suffer men to follow the law of races established by the Creator himself, and not to compel them to intermix contrary to their instincts.

West Chester \& Phila. R.R. v. Miles, 55 Pa. 209, 213-14 (1367) (emphasis added); see also id. at 212 (upholding regulation requiring racial segregation in seating "to prevent contacts and collisions arising from natural or well-known customary repugnancies" as "a proper use of the right of private property").

The Supreme Court employed similar reasoning in the Civil Rights Cases, 109 U.S. 3 (1883), when it struck down the Civil Rights Act of 1875 , which prohibited race discrimination in transportation, inns, and theaters, on the grounds that the statute exceeded Congress's powers under the Reconstruction Amendments. The Court denied that race discrimination in accommodations reflected the white-supremacist values of chattel slavery, and instead depicted such discrimination as an exercise of discernment in personal associations. The Thirteenth Amendment did not authorize the accommodations statute, because

[i]t would be running the slavery argument into the ground to make it apply to every act of discrimination which a person may see fit to make as to the guests he will entertain, or as to the people he will take into his coach or cab or car, or admit to his concert or theatre, or cleal with in other matters of intercourse or business.

Id. at 24-25. To explain why the Fourteenth Amendment did not authorize the accommodations statute, the Court also invoked concepts of privacy, here in the form of a federalism argument. The Court held that Section 1 of the Fourteenth Amendment did "not authorize Congress to create a code of municipal law for the regulation of private rights" but instead provided "modes of redress against [state action] subversive of the fundamental rights specified in the amendment." Id. at 11. Federal legislation under the Fourteenth Amendment

cannot properly cover the whole domain of rights appertaining to life, liberty and property, defining them and providing for their vindication. That would be to establish a code of municipal law regulative of all private rights between man and man in society. It would be to make Congress take the place of the State legislatures and to supersede them.

Id. at 13. (Gendered discourses of the private also supported federalism arguments in the nineteenth century, especially concerning family law. See infra text accompanying notes $311-15$.)

Joseph Singer is writing a detailed and provocative account of the ways in which racial concerns shaped conceptions of public accommodations and private property during the Reconstruction Era. See Joseph William Singer, No Right to Exclude: Public Accommodations and Private Property (1996) (unpublished manuscript, on file with author). For a fascinating account of the ways in which gender, class, and race interacted in producing the law of racial separation, see Barbara Y. Welke, When All the Women 
upheld racial segregation under the Fourteenth Amendment by reasoning that racial equality did not require "an enforced commingling of the two races":223

The object of the amendment was undoubtedly to enforce the absolute equality of the two races before the law, but in the nature of things it could not have been intended to abolish distinctions based upon color, or to enforce social, as distinguished from political equality, or a commingling of the two races upon terms unsatisfactory to either....

$\ldots$

... If the two races are to meet upon terms of social equality, it must be the result of natural affinities, a mutual appreciation of each other's merits and a voluntary consent of individuals. ${ }^{224}$

As Leon Litwack explains the logic of the segregationist regime that grew up in the aftermath of the Civil War:

Now that enslavement no longer marked a distinction between blacks and whites, the implications of physical contact were sufficiently obvious to whites. Equal access to public vehicles, theaters, restaurants, hotels, schools, parks, and churches would eventually open the door to the home, the parlor, and the bedroom. The absence of distinctions in public life thus prepared the way for no distinctions at all. ${ }^{225}$

The racial discourse of the private that the Court invoked in Plessy differed from the discourses of affective privacy employed to rationalize elements of marital status law during the same period, but functioned in strikingly similar ways: to explain laws enforcing status privileges, once justified in overtly hierarchy-based discourses, with reference to other, less contested, social values. 226

Were White, and All the Blacks Were Men: Gender, Class, Race, and the Road to Plessy, 1855-1914, 13 LAW \& HIST. REv. 261 (1995).

223. I63 U.S. 537, 551 (1896) (rejecting proposition that "social prejudices may be overcome by legislation, and that equal rights cannot be secured to the negro except by an enforced commingling of the two races").

224. Id. at $544,551$.

225. LITWACK, supra note 221, at 265. For an expression of this concern, see Miles, $55 \mathrm{~Pa}$. at 213-14, quoted supra note 222.

226. Judges called upon to reconcile Jim Crow with the Fourteenth Amendment disclaimed that they were enforcing a legal system predicated on values of white supremacy. By narrowly circumscribing the boundaries of law's "proper domain," legal elites defined an arena in which they could say that formal equality of citizenship prevailed between "the two races." Privacy talk, not hierarchy talk, was invoked to justify this restriction on the ambit of equal protection; thus, Plessy held that the Constitution would protect equality in "civil and political rights," but would not enforce equality in "social" rights, i.e., the "enforced commingling of the two races." Plessy, 163 U.S. at 551-52.

Over 60 years after Plessy was decided, Herbert Wechsler still viewed "freedom of association" as a "neutral principle" that justified a regime of separate-but-equal, and called into question the Court's 
There were significant differences in the rules and rhetoric that were employed to enforce racial status relations under chattel slavery and under Jim Crow. Yet, Plessy's interpretation of the Thirteenth Amendment notwithstanding, ${ }^{227}$ it plainly would be wrong to overlook the elements of continuity between regimes. ${ }^{228}$ During Reconstruction, the legal system still played a significant role in maintaining the differences in material and dignitary privilege that constituted "the two races," although it now did so by means of a new cluster of rules and rhetorics. In short, Jim Crow was a successor to chattel slavery that enforced the status relations we call "race" by somewhat less formalized means. I call this dynamic of preservation-throughtransformation in the structure of a status regime "deformalization" or "modernization."

Modernization of a status regime occurs when a legal system enforces social stratification by means that change over time. One commonly recognized way that law enforces social stratification is by according groups hierarchically differentiated entitlements and obligations. ${ }^{229}$ In antebellum America, the law of slavery and marriage enforced race and gender hierarchy by such overt means. But by the Reconstruction Era, the law of race and gender status had begun, slowly, to evolve, in diverse ways eschewing the overtly hierarchical forms of the antebellum period. In this era, the legal system continued to draw distinctions on the basis of race and gender, but it now began to emphasize formal equality of entitlements in relationships once explicitly organized as relationships of mastery and subordination, and to repudiate openly caste-based justifications for such group-based distinctions as the law continued to enforce. ${ }^{230}$ While the American legal system continued to distribute social

decision in Brown. See Herbert Wechsler, Toward Neutral Principles of Constitutional Law, 73 HARV. L. REV. 1, 34 (1959):

But if the freedom of association is denied by segregation, integration forces an association upon those for whom it is unpleasant or repugnant. ... Given a situation where the state must practically choose between denying the association to those individuals who wish it or imposing it on those who would avoid it, is there a basis in neutral principles for holding that the Constitution demands that the claims for association should prevail?

227. See Plessy, 163 U.S. at 543 ("A statute which implies merely a legal distinction between the white and colored races-a distinction which is founded in the color of the two races, and which must always exist so long as white men are distinguished from the other race by color-has no tendency to destroy the legal equality of the two races, or reëstablish a state of involuntary servitude."); see also Miles, $55 \mathrm{~Pa}$. at 213-14 ("But to assert separateness is not to declare inferiority in either; it is not to declare one a slave and the other a freeman - that would be to draw the illogical sequence of inferiority from difference only.").

228. See, e.g., LITWACK, supra note 221, at 376-79 (explaining that post-Civil War labor regimes perpetuated dependence of freedmen on former masters).

229. See BRYAN S. TURNER, STATUS 2-8 (1988) (discussing literature on status, with particular attention to sociology of ascriptive status groups, which are organized on basis of attributes over which individuals have little or no control, such as gender or race).

230. For examples of the emergent interest in rule-equality, see supra note 222 (upholding racial segregation in accommodations) and supra text accompanying note 142 (announcing immunity for interspousal assault). See also Siegel, Home As Work, supra note 38, at 1170-73 (tracing emergence of rule-equality in marital inheritance rights during postbellum period). In this period, judges who engaged in justifying laws that tended to preserve race and gender stratification began expressly to disavow caste- 
goods and privileges in ways that favored whites and males, it now began selfconsciously to disavow its role in doing so. The new interest in rule-equality and the energy devoted to explaining law without recourse to overtly castebased justifications mark an important shift in the mode of regulating race and gender relations, a deformalization and concomitant modernization of status law.

Civil rights agitation plays a significant role in precipitating the modernization of status regimes. Abolitionist protest (and a civil war) contributed to the modernization of racial status law during the Reconstruction Era, just as woman's rights protest contributed to the modernization of gender status law during this same period. If successful, protest of this sort will draw the legitimacy of a status regime into question, and so bring pressure to bear on lawmakers and other legal elites to cede status privileges. In such circumstances, legal elites may begin to cede status privileges, but they will also defend them. They will initially defend privileges within the traditional rhetoric of the status regime-but because the traditional rhetoric of the status regime is now socially contested, they will begin to search for "new reasons" to justify such status privileges as they choose to defend. As reform of the common law marital status rules illustrates, this process of ceding and defending status privileges will result in changes in the constitutive rules of the regime and in its justificatory rhetoric-with the result that, over time, status relationships will be translated from an older, socially contested idiom into a newer, more socially acceptable idiom. In short, civil rights reform is an important engine of social change. Yet civil rights reform does not simply abolish a status regime; in important respects, it modernizes the rules and rhetoric through which status relations are enforced and justified.

Considered from this vantage point, status law has no "essential" or transhistorical form. Instead, the manner in which a legal system enforces social stratification will evolve over time, changing shape as it is contested. Attempts to dismantle a status regime, if successful, will discredit the rules and reasons employed to enforce status relations at a particular juncture in history, and create pressure for elites to reform the contested body of law sufficiently so that the regime that emerges from reform can be differentiated from its contested predecessor. Assuming that something of value is at stake in such a struggle, it is highly unlikely that the regime that emerges from reform will redistribute material and dignitary "goods" in a manner that significantly

based justifications for the rules. This was especially true in matters of race, because segregative practices had to be reconciled with federal antidiscrimination law, see supra notes 222-28 and accompanying text. Reform of gender status law through the married women's property acts proceeded more incrementally, with judges continuing to invoke the hierarchical tenets of marital unity doctrine as they interpreted the reform statutes throughout the nineteenth century; but, as reform progressed, judges began to repudiate overtly caste-based rationales and seek other reasons of "public policy" to justify status-enforcing features of the body of marriage law that emerged from reform, see, e.g., supra text accompanying notes 181-91. 
disadvantages groups that were the beneficiaries of the prior, contested regime. But for the regime that emerges from reform to reestablish its legitimacy, it must distribute social goods in a manner that can be differentiated from the prior, contested regime. The dynamic of negation and differentiation precipitated by the quest to reestablish legitimacy produces constant mutation in the properties of a body of status law. Social struggle over the legitimacy of a status regime will produce changes in its formal structure until such a point as its legitimacy can be reestablished and the reformed body of law can once again be justified as "reasonable." At this point, the legal system may still be enforcing social stratification, but by new means: Especially under changing social conditions, it is possible to modify the rules and reasons by which the legal system distributes social goods so as to produce a new regime, formally distinguishable from its predecessor, that will protect the privileges of heretofore dominant groups, although not necessarily to the same degree.

The dynamic of preservation-through-transformation that I am describing need not arise through the conspiratorial or malevolent motivations of the legal elites directing reform. Indeed, we can posit for purposes of argument that the legal elites who implement these changes in the constitutive rules and rhetoric of a status regime are acting in "good faith." For example, I assume that the judges who repudiated marital chastisement, yet developed the interspousal tort immunity doctrine to constrain interpretation of the married women's property acts, did not snicker in the robing room in gleeful appreciation of their interpretive sophistry. They could well have harbored the good faith conviction that privacy and domestic harmony were important social values that required protection as they superintended the marriage relation through a period of turbulent legal transformation. Thus, as judges contemplated the question of whether the reform statutes granting married women a tort claim for injury to their persons and property should be construed to enable wives to sue their husbands, judges could well have decided, in all sincerity, that considerations of "public policy" warranted interpreting the statutes to bar the claim.

Yet it also seems clear that, as educated, propertied men, judges reasoned about this question within certain legal traditions and from a certain social position that predisposed them to certain legal conclusions. Judges who initially adopted the tort immunity rule openly embraced it as preserving elements of the doctrine of marital unity; only as the doctrine of marital unity was progressively discredited did courts come to rely exclusively on justifications couched in the discourse of affective privacy. ${ }^{231}$ Moreover, given the social position from which judges reasoned about "public policy,"

231. Some courts expressed a continuing commitment to the unity concepts of the common law; others expressed their concerns in the course of interpreting the married women's property acts, asserting that statutes in derogation of the common law were to be construed narrowly. See supra text accompanying notes $164-80$. 
they were far more likely to appreciate the benefits of the tort immunity rule (to propertied husbands) than to register its costs (to battered wives) - a phenomenon Paul Brest has elegantly dubbed "selective sympathy and indifference."232 Of course, we can assume that at least some of these judges had the critical faculties to discern, and thus to correct for, the biases to which their deliberative processes were subject. Sometimes, however, critical oblivion is bliss, especially when it is interest-convergent.

Were the legal elites who helped translate marital status law from older, hierarchy-based discourses into the discourses of affective privacy in any significant sense responsible for the results of their deliberations, or were they just reflecting and enforcing wider social mores? ${ }^{233}$ If, for purposes of argument, we momentarily reify the distinction between "law" and "society,"234 we can see that legal actors drew on popular understandings of companionate marriage as they interpreted the married women's property acts-a scenario that certainly supports the "reflectionist" hypothesis. But, in this act of interpretation, judges were also acting creatively and synthetically: binding "privacy" to violence and thus renaming the chastisement prerogative for all those subject to law.

There is remarkably little scholarship on the social history of privacy discourses; consequently, we know very little about the ways in which conceptions of privacy shaped popular understandings of marriage, or marital violence, in the nineteenth century. But there is no reason to assume that,

232. Paul Brest, The Supreme Court, 1975 Term-Foreword: In Defense of the Antidiscrimination Principle, 90 HARV. L. REV. I, 7-8 (1976) (discussing race discrimination).

233. In reflecting on this question, it is helpful to consider the distinction that Austin Sarat and Thomas Kearns draw between "instrumental" and "constitutive" perspectives on the law-and-society relationship. See Austin Sarat \& Thomas R. Kearns, Beyond the Great Divide: Forms of Legal Scholarship and Everyday Life, in LAW IN EvERYDAY LIFE 21 (Austin Sarat \& Thomas R. Keams eds., 1993). Of the instrumentalist view, Sarat and Kearns observe:

Law, in the instrumentalist account, mirrors society. Changes in law tend to follow social changes and often intend to do no more than make those changes permanent. Legal rules are used to maintain, reproduce, and alter the everyday in conscious, rational, and planned ways. Instrumentalism denies that law is already an integral part of that which it regulates.

Id. at 25 (footnote omitted). While instrumentalism "conceives of law as largely external to the social practices it regulates," the constitutive conception of law detects its effects "in meanings and selfunderstandings rather than in the results of sanctions." Id. at 27.

[T] hose who adopt the constitutive perspective believe that law permeates social life and that its influence is not adequately grasped when law is treated as an external, normative missile launched at independent, ongoing activities. . . . We are not, as instrumentalists suggest, merely pushed and pulled by laws that impinge on us from the outside. Rather, we have internalized law's meanings and its representations of us, so much so that our own purposes and understandings can no longer be extricated from them.

Id. at 29; Reva B. Siegel, In the Eyes of the Law: Reflections on the Authority of Legal Discourse, in LAW's STORIES 225, 226 (Paul Gewirtz \& Peter Brooks eds., 1996) thereinafter Siegel, In the Eyes of the Law] ("[W]e are not always conscious of how legal discourse exerts authority in our lives, for the simple reason that we understand important aspects of our social universe through the language of the law"; law thus "plays a more pervasive and less perceptible role in ordering social relationships" than is often appreciated.).

234. Cf. Robert W. Gordon, Critical Legal Histories, 36 STAN. L. REV. 57, 59-60, 102-13 (1984) (analyzing and deconstructing relationship between "law" and "society"). 
before demise of the chastisement prerogative, married persons understood a traditional prerogative of marriage, rooted in notions of a husband's authority as master and head of his household, in a framework of "privacy" and "domestic harmony."235 It seems just as likely that legal elites devised the story linking "privacy" and "domestic harmony" to wife beating in the wake of chastisement's demise (or in anticipation of $\mathrm{it}^{236}$ ). After all, even if we posit that values of privacy had currency in nineteenth-century conceptions of marriage, that still does not tell us much about the particular practices to which values of privacy would be discursively bound. Why did an interspousal tort claim raise questions of marital privacy in the Reconstruction Era, when laws restricting contraception and abortion or forbidding polygamy-all of which were enacted during this same period ${ }^{237}$-did not? Then as now, discourses of privacy are employed in gender-, class-, and race-salient ways, and the legal system seems to play a significant role in directing their divergent social application. ${ }^{238}$

235. The few accounts we have of domestic assault cases from the late nineteenth century report that men reasoned about their wives in the language of prerogative and property. See Cobbe, supra note 15:

Every brutal-minded man, and many a man who in other relations of life is not brutal, entertains more or less vaguely the notion that his wife is his thing, and is ready to ask with indignation (as we read again and again in the police reports), of any one who interferes with his treatment of her, 'May I not do what I will with my own?' It is even sometimes pleaded on behalf of poor men, that they possess nothing else but their wives, and that, consequently, it seems doubly hard to meddle with the exercise of their power in that narrow sphere!

Id. at 62-63; see also Haag, supra note 50, at 462 ("[T] he right of men to the property of their wives surfaces most perniciously in the language of possession and almost annihilistic sense of prerogative that color testimonies of domestic assault.").

236. Cf. supra notes $129-32$ and accompanying text.

237. See MiCHAEL GROSSBERG, GoverNiNG THE HEARTH: LAW AND tHE FAMILY IN NINETEENTHCENTURY AMERICA 120-26, 155-95 (1985) (discussing nineteenth-century attempts to regulate polygamy, contraception, and abortion); see also Siegel, Reasoning from the Body, supra note 119, at 282 (exploring nineteenth-century campaign to criminalize abortion and contraception); Sarah Barringer Gordon, "The Twin Relic of Barbarism": A Legal History of Anti-Polygamy in Nineteenth-Century America (1995) (unpublished Ph.D. dissertation, Princeton University) (offering in-depth account of campaign against polygamy).

238. Compare Roe v. Wade, 410 U.S. 113 (1973) (concluding that right to privacy protects abortion decision) with Harris v. McRae, 448 U.S. 297 (1980) (finding that government program that pays for childbirth but not abortion expenses of poor women does not interfere with exercise of their constitutionally protected privacy right to make decisions about abortion). The gender-, class-, and race-salience of privacy discourses is also apparent in contemporary proposals for birth-deterring regulation of poor women (e.g., drug-dependent pregnant women and welfare recipients). See Reva B. Siegel, Abortion as a Sex Equality Right: Its Basis in Feminist Theory, in MOTHERS IN LAW: FEMINIST THEORY AND THE LEGAL REGULATION OF MOTHERHOOD 43, 56-57 (Martha Albertson Fineman \& Isabel Karpin eds., 1995) [hereinafter Siegel, Abortion as a Sex Equality Right] (comparing and distinguishing birth-compelling and birth-deterring regulation of women's conduct); Siegel, Reasoning from the Body, supra note 119, at 344 ("Would this society so readily contemplate criminal prosecution, 'protective' incarceration, or custody-deprivation as responses to maternal addiction if the policies were to be applied to privileged women rather than the poor? ... [T] oday as in the past, judgments about motherhood in this society are delineated by class and race, as well as by sex."). See generally Dorothy E. Roberts, Punishing Drug Addicts Who Have Babies: Women of Color, Equality, and the Right of Privacy, 104 HARV. L. REV. 1419, 1419-82 (1991) (demonstrating that constitutional privacy doctrines are applied in race- and class-salient fashion, and proposing new legal protections for women of color). 
Similarly, even if we construe the law or society "causation" question more loosely - to mean, for example, that married couples expected and desired state actors to avoid regulating episodes of marital violence-it is difficult to see how such a social expectation could be said to enter the legal system from "outside" the law; to the contrary, such a social expectation would have been constituted by and under the law of chastisement itself. Although judges often talked about the affective life of a marriage relationship as if it were positively and normatively "outside" of law, this figure of speech scarcely conceals the centrality of law in constructing the institution of marriage or the feelings it "engenders." Both the chastisement rule and the network of formal and informal regulatory immunities that took its place authorized (in differing degrees) conduct within the marital relationship that was not tolerated by the legal system in other relationships.

Rather than treat discourses of affective privacy as aspects of "society" that shaped the legal system, it thus seems heuristically useful to consider just how large a role the legal system played in constructing the aspects of society to which it claimed to defer. Judges rhetorically constructed the world "outside" the boundaries of law in the course of invoking it as a "reason" for the legal decisions they sought to justify. Indeed, it seems that the constitutive imperatives of the legal system predispose it to such acts of narrative creativity. Specifically, the aspiration to govern by "rule of law" creates a need for principled reasons to account for particular decisions-particularly those decisions involved in the partial disestablishment of a socially contested status regime. ${ }^{239}$ Of course, judges interpreting the tort provisions of the married women's property acts could have declared that wives now had the capacity to sue "anyone except their husbands," but to interpret the reform statutes in this fashion without providing a reason to distinguish the excepted case from all others would reveal the decision itself as "lawless." By contrast, producing principled reasons to account for a partial reform of a status regime formally satisfies the requirements of justice. At one and the same time, the process of rationalizing partial reform modernizes the rhetoric in which privilege is justified. ${ }^{240}$ Considered from this standpoint, law would appear to be a double-edged weapon of social change, repeatedly demonstrating the capacity to legitimate privileges it seems at first to challenge.

239. It was for this reason that values of "privacy" came to play such a significant role in justifying racial and gender status law during the Reconstruction Era, explaining legal rules that might have been justified in hierarchy-based thetoric during the antebellum era. See supra note 230 and accompanying text.

240. Of all legal elites, judges are perhaps the most subject to the imperative to rationalize their action with "reasons"; the "split-the-difference" approach to compromise that characterizes legislative activity does not suffice to justify the act of judging. Finally, judges are trained in the art of interpretive "translation": They regularly apply old doctrines to new fact situations, seeking to do so in a fashion that has fidelity to the past. Cf. Lawrence Lessig, Understanding Changed Readings: Fidelity and Theory, 47 STAN. L. REV. 395,443 (1995) ("Translation yields different readings of what went on before only to make what went before understandable to the reader today. Its aim is not to change the past, but to recover it, as if (for we can always act as if) we can recover without changing."). 
Does this inquiry into the modernization of status regimes turn out to be a story about stasis after all? Is Jim Crow slavery by another name, and the network of formal and informal immunities for wife beating that emerged during Reconstruction the functional equivalent of chastisement? As I indicated at the outset of this discussion, I believe that the dynamic I am describing can fairly be called one of preservation-through-transformation, or characterized in any way that indicates that elements of continuity and change are at stake in the process. A status regime is modernized (or deformalized) when, despite changes in its rules and rhetoric, it continues to distribute material and dignitary privileges ("social goods") in such a way as to maintain the distinctions that comprise the regime (e.g., constitute "race" or "gender") in relatively continuous terms. But modernization of a status regime may still bring about perceptible, even significant, changes in status relations. ${ }^{211} \mathrm{We}$ can posit that African-Americans were "better off" under a regime of Jim Crow than a regime of chattel slavery, certainly in terms of dignitary values, and possibly in terms of their material welfare as well. Similarly, we can posit that married women were "better off" under a regime of formal and informal immunities for wife beating, certainly in terms of dignitary values, and, possibly, in terms of their material welfare as well.

There is, however, one way in which members of each group were indisputably worse off: in their capacity to achieve further, welfare-enhancing reform of the status regime in which they were subordinated. By the midnineteenth century, slavery and marital status law (chastisement, in particular) were socially contested and substantially discredited practices. They lacked legitimacy in the eyes of many. But once racial status law and marital status law were reformed in the Reconstruction Era, each status regime gained substantially in legitimacy. As each regime was translated from contested rules and rhetorics into more contemporary rules and rhetorics, each was again "naturalized" as just and reasonable, in significant part because each was now formally and substantively distinguishable from its contested predecessor: Each could be justified in terms of social values that were distinct from the orthodox, hierarchy-based norms that characterized its predecessor (slavery, marriage) as a regime of mastery. Considered from this perspective, we can see that civil rights reform may alleviate certain dignitary or material aspects of the inequalities that subordinated groups suffer; but we can also see that civil rights reform may enhance the legal system's capacity to legitimate residual social inequalities among status-differentiated groups.

Of course, struggle persists, and oftentimes subordinated groups can exploit the semantic instability of status discourses for their own resistance purposes. After many decades, the rhetoric of separate but equal was turned against Jim Crow, and the discourse of privacy developed a constitutional life

241. See supra text accompanying notes $227-31$. 
that would have startled the nineteenth-century judiciary. ${ }^{242}$ It might seem that such developments would tend ultimately to destabilize regimes of race and gender status. ${ }^{243}$ Yet the dynamic runs in both directions. Protest or resistance discourses are semantically unstable as well, with the result that rhetorics employed by recent civil rights movements to challenge laws enforcing race- and gender-status relationships are now being turned to statuspreserving ends. As the recent life of the colorblindness trope illustrates, civil rights rhetoric can supply "legitimate," "nondiscriminatory" reasons for opposition to affirmative action ${ }^{244}$ and other reforms ${ }^{245}$ intended to break

242. To date, few scholars have explored the common law roots of constitutional privacy doctrines. An exception is Barbara Woodhouse, who has provided a rich account of the diverse social forces shaping the Supreme Court's first family privacy cases: Meyer v. Nebraska, 262 U.S. 390 (1923), and Pierce v. Society of Sisters, 268 U.S. 510 (1925). See Barbara B. Woodhouse, "Who Owns the Child?": Meyer and Pierce and the Child as Property, 33 WM. \& MARY L. REV. 995 (1992). Woodhouse demonstrates how the parental liberty interest recognized in Meyer and Pierce drew upon parental property interests in children of the sort long recognized in the Anglo-American common law tradition. See id. at 1036-50, 1064-68, 1089-91. On the common law tradition giving the male head of the household mastery over its members, see supra text accompanying notes $18,102$.

243. For a skeptical evaluation of the emancipatory potential of privacy discourses, see CATHARINE A. MACKINNON, FEMINISM UNMODIFIED: DISCOURSES ON LIFE AND LAW 101-02 (1987) (observing that there is something problematic in feminists "seeking protection [for abortion] behind a right to . . . privacy" when "the legal concept of privacy ... has shielded the place of battery, marital rape, and women's exploited labor; has preserved the central institutions whereby women are deprived of identity, autonomy, control and self-definition"); Roberts, supra note 238, at 1463-71 (analyzing ways in which privacy discourses have failed to protect women of color). For a skeptical evaluation of the values of racial assimilation embraced by Brown, see Jerome M. Culp, Jr., Black People in White Face: Assimilation, Culture, and the Brown Case, 36 WM. \& MARY L. REV. 665, 675-82 (1995) (arguing that Brown and cases following it replaced a regime of racial segregation with a regime of putatively race-neutral policies that tacitly privilege white over African-American culture). See also Anthony E. Cook, The Spiritual Movement Towards Justice, 1992 U. ILL. L. REV. 1007, 1012 (remarking of Brown that "[w]hat was promised to be a program of integration has turned out to be one of assimilation in which the racist assumption of White superiority was left unchecked"); $c f$. Steven A. Holmes, Look Who's Saying Separate is Equal, N.Y. TIMES, Oct. 1, 1995, \$ 4, at 1 (describing various forces in African-American community that have recently expressed support for new forms of racial separatism).

244. See Siegel, In the Eyes of the Law, supra note 233, at 228-31 (tracing life of "colorblindness" trope in postslavery discourses of citizenship); see also J.M. Balkin, Ideological Drift and the Struggle Over Meaning, 25 CONN. L. REV. 869, 872-73 (1993) (tracing "ideological drift" of colorblindness trope).

Arguments against affimative action do not simply employ the language of colorblindness and formal equality; they often explicitly invoke the mantle of the civil rights movement of the 1950s and 1960s. So, for example, when Senator Robert Dole announced his support for California legislation prohibiting affirmative action, he asserted that "the voters of California can strike a blow for the principle of equal opportunity by passing the California Civil Rights Initiative," explaining that "[t]he initiative is a direct descendant of the Civil Rights Act of 1964." Bob Dole, End of Quotas, Discrimination Deserves Vote, ARIZ. REPUBLIC, Nov. 27, 1995, at B7. Opponents of affirmative action programs draw upon the language of the civil rights tradition in diverse ways. For instance, see Michelle A. McManus, End the Discrimination of Affirmative Action, DETROIT NEwS, Oct. 27, 1995, at A9:

Continued affirmative action quotas relegate women and minorities to second-class citizen

status. The message it sends declares them inferior to men and whites and in need of government regulation to get a job, gain entrance to college or eam a scholarship. America makes victims of more than half its citizens with the sham of affirmative action.

See also Paul C. Roberts, The Rise of the New Inequality, WALL ST. J., Dec. 6, 1995, at A20 ("Over the past two decades we have inadvertently created a caste society in which there are two classes of citizens: those who are protected by civil rights laws and white males, who are not."). In these arguments, affirmative action and other forms of race-conscious remedies are equated with the racism the civil rights movement fought. See, e.g., Jonathan J. King, Affirmative Action Serves to Destroy and Divide Nation, FRESNO BEE, Sept. 23, 1995, at BS ("Liberals .... are locked into an orthodoxy that requires human 
down remaining racial and gender inequalities. This change in the political valence of civil rights discourse-a phenomenon Jack Balkin calls "ideological drift" 246 - occurs as those who oppose current strategies to break down race and gender stratification seek to justify their opposition in terms that can be differentiated from a naked interest in preserving race and gender

beings to be classified by race by government authorities; a practice as evil as anything they are fighting."); Joseph Neff, Future of Race-Based Districting May Ride On N.C. Case, RALEIGH NEwS \& OBSERVER, Dec. 5,1995 , at A1 ("'There should not be racial quotas for any political office, and districts should not be drawn with the view of getting racial results. ... If we have this sort of thing, we might as well go back to the era when we had separate entrances to buildings and separate seating in theaters." (quoting plaintiff in voting rights case)); Richard Rorty, Color-Blind in the Marketplace, N.Y. TIMES, Sept. 24, 1995, § 7 (Book Review), at 9 (quoting author Dinesh D'Souza as arguing that "'[t]oday the most formidable ideological barrier facing blacks ... is not racism but antiracism"').

Of course, this dynamic extends well beyond the affirmative action context. In a forthcoming account of the attack on "political correctness," Jamie Boyle, Mark Hager, and Jamie Raskin argue that the most remarkable shift in conservative rhetoric in the nineteen nineties was the wholesale-rather than retail-adoption of the language of formal equality, and its use to attack everything from speech codes and affirmative action, to communications policy and product liability law. This shift has been going on for a long time, but it is at its clearest and most conscious in the remarkable linkages that a group of conservative intellectuals drew between the regulation of speech on campuses, minority scholarships, affirmative action hiring and feminist or Afrocentrist teaching. To put it bluntly, the PC debate is the historical moment when the language of formal equality - the lingua franca of the early civil rights movement-passes from liberals to conservatives.

James Boyle et al., "Politically Correct": Conservative Mythologies in Higher Education 4 (1995) (unpublished manuscript, on file with author).

245. Feminist and antiracist arguments about "essentialism" are now being appropriated and transformed by opponents of race-conscious remedies, much as the colorblindness argument was. Initially, scholars analyzing gender and race stratification described how an observer's social status or position could influence her perception of social relationships, arguing that this kind of positional bias often results in "essentialist" claims-generalizations about a group that reflect the experience of certain, socially privileged group members rather than the experience of all group members. See, e.g., FEMINIST LEGAL THEORY: READINGS IN LAW AND GENDER 201-80 (Katharine T. Bartlett \& Rosanne Kennedy eds., 1991) (group of essays by Robin West, Angela Harris, and Patricia Cain written between 1988 and 1990 that expose, respectively, gendered assumptions of male legal theorists, racial assumptions of white feminist legal theorists, and sexual assumptions of heterosexual feminist legal theorists); ELIZABETH V. SPELMAN, INESSENTIAL WOMAN: PROBLEMS OF EXCLUSION IN FEMINIST THOUGHT (1988) (analyzing ways in which feminist claims about "women" often reflect experience and concerns of white and otherwise privileged members of group). By the late 1980s, the critique of essentialism was appropriated by critics who were not interested in problems of positional bias, but instead objected to the possibility of making any general claims about the distinctive situation, experience, or "voice" of groups that have suffered discrimination. See generally Angela P. Harris, Foreword: The Jurisprudence of Reconstruction, 82 CAL. L. REV. 741, 754-55 (1994) (describing "essentialism" debate).

With this new focus, the critique made its way into Supreme Court jurisprudence, supplying a new basis for objecting to "benign," race-conscious civil rights measures (e.g., race-based preferences in the award of radio-broadcast licenses; race-conscious design of voting districts). Not only did such race-based programs discriminate against white people; now they were also said to discriminate against people of color by making "stereotypical" assumptions about the perspectives or opinions of people of color. See, e.g., Miller v. Johnson, 115 S. Ct. 2475, 2486 (1995) ("When the State assigns voters on the basis of race, it engages in the offensive and demeaning assumption that voters of a particular race, because of their race, 'think alike, share the same political interests, and will prefer the same candidates at the polls." (quoting Shaw v. Reno, 113 S. Ct. 2816, 2827 (1993))); Metro Broadcasting, Inc. v. FCC, 497 U.S. 547, 604 (1990) (O'Connor, J., dissenting) ("Such [race-based] policies may embody stereotypes that treat individuals as the product of their race, evaluating their thoughts and efforts-their very worth as citizens-according to a criterion barred to the Government by history and the Constitution.").

246. See Balkin, supra note 244. 
stratification. ${ }^{247}$ While many justifications might suffice for these purposes, claiming fidelity to principles of equality would seem to provide an unimpeachable reason for opposing current programs for breaking down race and gender stratification. ${ }^{248}$ Because the rule structure of contemporary race and gender status law has changed in response to demands for color- and sexblindness that have been advanced by the civil rights movement over the last several decades, ${ }^{249}$ the movement's language now supplies a basis for opposing current civil rights strategies for reducing race and gender stratification. ${ }^{250}$ Under such circumstances, old protest discourses (such as colorblindness) are especially susceptible to capture, "drift," or cooptation, as they justify adherence to the status quo in terms that are especially difficult to impugn. ${ }^{251}$ As I observed at the outset of this discussion, status talk is mutable and remarkably adaptable, and will evolve as the rule structure of a status regime evolves. ${ }^{252}$

In offering these reflections on civil rights reform, I do not intend to posit any iron "law" of history that operates transcontextually and ineluctably to modernize status relations in accordance with scientifically predictable principles. Yet, I intend my comments to extend beyond the story of marital chastisement alone. I have explored the modernization of status discourses in prior work on the reform of marriage law (involving domestic labor and abortion laws), ${ }^{253}$ and discern some frequently recurring, if not absolutely regular, features of civil rights reform that are worthy of consideration. These

247. See supra text accompanying notes $227-31$.

248. One might oppose affirmative action because it is against the interests of white males, but such a reason could be characterized as an interest in preserving race and gender stratification itself. $C f$. Robert Pear, Report to Clinton Has a Mixed View on Minority Plans, N.Y. TimES, May 31, 1995, at Al ("A confidential report prepared for the President ... analyzes the reasons for 'white male resentment' of [affirmative action]"; during recent speech to California Democratic party, the President declared, "'This is psychologically a difficult time for a lot of . . . so-called angry white males,' who feel they have been treated unfairly."). If instead one opposes affirmative action out of fidelity to principles of equality that Martin Luther King espoused, one stands on moral high ground. Thus, when the President recently attributed opposition to affirmative action to the resentment of "angry white males," see Pear, supra, the editor of the New Republic publicly chastised him, complaining that "Mr. Clinton can only understand the opposition as a response of 'white males.' He doesn't seem to have noticed that there are other principles involved, such as those of faimess and liberty." Andrew Sullivan, Let Affirmative Action Die, N.Y. TIMES, July $23,1995, \S 4$, at 15 .

249. See infra text accompanying notes 254-75; see also Siegel, In the Eyes of the Law, supra note 233, at 230.

250. See supra note 245.

251. Of course, nothing in the account of modernization I offer requires that new status discourses be generated out of coopted protest discourses. For example, the discourse of affective privacy was only tangentially related to the advocacy of the woman's rights movement, which embraced companionate marriage concepts, but generally deployed them in more egalitarian terms. On the other hand, my account of the modernization of status regimes does explain why old protest discourses are especially attractive candidates for cooptation into status discourses. As I indicate in the text, old protest discourses provide seemingly unimpeachable grounds for defending the structure of a status regime when its legitimacy is under attack.

252. See supra text accompanying note 220.

253. See Siegel, Abortion as a Sex Equality Right, supra note 238; Siegel, Modernization, supra note 38; Siegel, Reasoning From the Body, supra note 119. 
reform dynamics deserve consideration because they are recurring today in the wake of the civil rights revolutions of the 1960s and 1970s, and because there is little in the current Court's understanding of equal protection that conduces to their public discussion.

\section{B. Contemporary Perspectives}

To what extent is the legal system responsible for the continuing race and gender stratification of American society? Today it is commonplace to distinguish between de jure and de facto discrimination - and to attribute some aspects of race and gender stratification to state action and others to "social" factors that might reflect "the continuing effects of past discrimination." Largely unarticulated in such accounts of de jure and de facto discrimination is any theory about what kinds of state action are discriminatory, or statusenforcing. Most often it is tacitly assumed that race- or gender-specific state action is status-enforcing, while so-called "facially neutral" state action is not.

This way of reasoning about the de jure-de facto distinction has its roots in equal protection doctrines requiring "heightened scrutiny" of race- or gender-specific state action. ${ }^{254}$ Under the pressure of this constitutional requirement, laws that only recently were cast in race- or gender-specific terms have been revised so that they are now cleansed of any race- or gender-specific references. ${ }^{255}$ As a consequence, the persisting race and gender stratification of American life is commonly (and often legally) attributed to "the continuing effects of past discrimination," rather than to current, "facially neutral" forms of state action. ${ }^{256}$

254. See, e.g., Craig v. Boren, 429 U.S. 190, 197 (1976) (applying intermediate standard of scrutiny which requires "that classifications by gender must serve important governmental objectives and must be substantially related to achievement of those objectives"); Loving v. Virginia, 388 U.S. 1 (1967) (applying "strict scrutiny" to race-based state action).

255. See infra text accompanying notes 260-80 (discussing impact on domestic violence policies).

256. For a popular expression of this conviction, see King, supra note 244, at B5:

From the creed that pervasive racism defines America has developed an equally destructive axiom: The wrongs done to individuals in the past must be remedied by ensuring that the victims' ethnic or racial groups are proportionally represented in every institution and endeavor. It does not matter if we are generations removed from the wrongs.

Id. (emphasis added). See also Pamela Newkirk, At Lunch with Bebe Moore Campbell, N.Y. TIMES, Nov. 15,1995 , at $\mathrm{CI}$ ("Take affirmative action and the rage of the white male. 'I understand where they're coming from,' [Campbell] said. 'They're saying: "My parents didn't own slaves. Let's get on with it."'"); Noel R. Wood, What Next? Ban Old Glory?, ROANOKE TIMES \& WORLD NEWS, July 31, 1993, at A9 (arguing that Senators who voted to end patent protection for Daughters of Confederacy seal wronged "[author's] great grandfathers ... who did not own slaves").

The view that social stratification by race and gender is the result of overtly classificatory practices of the past (rather than facially neutral practices of the present) is expressed in diverse ways by actors in the legal system. See, e.g., Fullilove v. Klutznick, 448 U.S. 448, 465 (1980) ("'The effects of past inequities stemming from racial prejudice have not remained in the past. The Congress has recognized the reality that past discriminatory practices have, to some degree, adversely affected our present economic system." (quoting H.R. REP. No. 468, 94th Cong., 1st Sess. 1-2 (1975))); Podberesky v. Kirwan, 956 F.2d 52, 57 (4th Cir. 1992) (refusing to award race-based remedy absent showing of "some present effect" of past discrimination where "identifiable discrimination [as distinct from facially neutral policies] occurred a 
There is little in contemporary equal protection doctrine that challenges this view. The Court will hear arguments that race- or sex-based state action is discriminatory; otherwise it requires plaintiffs to prove that facially neutral state action is motivated by a discriminatory purpose. ${ }^{257}$ Yet, the Court has construed "discriminatory purpose" to be a state of mind akin to malice, ${ }^{258}$ and, as the Court itself has acknowledged, it is exceedingly difficult to prove "discriminatory purpose" once it is defined in this way:. ${ }^{259}$ Lawmakers can always articulate socially benign (or at least, nonmalicious) reasons for policies they adopt that may "incidentally" perpetuate status inequalities among groups. Cumulatively, this body of equal protection doctrine has given lawmakers a strong incentive to change the rule structure of policies that long enforced racial or gender stratification and to articulate "legitimate, nondiscriminatory reasons" for those policies in order to immunize them from further equal protection challenge.

Thus, the civil rights revolutions of the 1960s and 1970s precipitated a shift in the rule structure and justificatory thetoric of laws that long played a role in enforcing race and gender status relations. Given that today most state action has been cleansed of race- and gender-specific references, can we assume, as both the Court and the American public seemingly have, that by virtue of these reforms, the state has generally withdrawn from the business of enforcing race and gender status relations?

We might consider this question by examining how equal protection doctrines of heightened scrutiny have affected law enforcement policies regulating marital violence. While general criminal assault statutes were often used to regulate "domestic disturbances," it was also commonplace for judicial opinions, statutes, and law enforcement policies to refer to the conduct as "wife beating" or otherwise to discuss the parties involved in gender-specific

number of years in the past"), cert. denied, 115 S. Ct. 2001 (1995); Paul Gewirtz, Remedies and Resistance, 92 YALE L.J. 585, $675 \mathrm{n} .245$ (1983) (terming attempts to "reduce[] an underrepresentation of blacks in the employer's workforce attributable to past discrimination" "the more traditional justification for affirmative action"). But cf. Charles R. Lawrence III, The Id, the Ego, and Equal Protection: Reckoning with Unconscious Racism, 39 STAN. L. REV. 317, 322 (1987) (challenging "false dichotomy" shaping Supreme Court's view "of facially neutral actions as either intentionally and unconstitutionally or unintentionally and constitutionally discriminatory").

257. See Washington v. Davis, 426 U.S. 229 (1976) (requiring plaintiffs who challenge facially neutral state action as violating equal protection to demonstrate that challenged practice was animated by discriminatory purpose).

258. See Personnel Adm'r v. Feeney, 442 U.S. 256, 279 (1979) (“'Discriminatory purpose'. . . implies more than intent as volition or intent as awareness of consequences.... It implies that the decisionmaker ... selected or reaffirmed a particular course of action at least in part, 'because of,' not merely 'in spite of,' its adverse effects." (citation omitted)).

259. In a recent voting rights decision, the Court bluntly observed that "[t]he distinction between being aware of racial considerations and being motivated by them may be difficult to make." Miller v. Johnson, 115 S. Ct. 2475, 2488 (1995). Because it is so hard to prove discriminatory purpose under the Equal Protection Clause, most institutions, practices, and values are constitutionally characterized as race-neutral. For example, in Miller the Court characterized the practice of drawing voting-district lines to reflect "compactness, contiguity, respect for political subdivisions or communities defined by actual shared interests" as an expression of "traditional race-neutral districting principles." Id. 
terms. ${ }^{260}$ After 1976, when the Court decided in Craig v. Boren ${ }^{261}$ that sexbased state action would be subject to a heightened or intermediate standard of review under the Equal Protection Clause of the Fourteenth Amendment, all this began to change. Residual gender-specific references were deleted from the law and replaced with gender-neutral language, with the result that the conduct is now generally referred to as "spousal assault" or "domestic violence."262

This process of historical revision occurred throughout the country. For example, a clause in Alabama's constitution dating from the Reconstruction Era provided for the disenfranchisement of wife beaters (its author estimated that it would disenfranchise "sixty percent of the Negroes"263); in 1977, the rule was struck down under the Equal Protection Clause of the Fourteenth Amendment-on the grounds that it constituted sex discrimination against men. ${ }^{264}$ In 1977, after California's statute prohibiting wife beating was threatened by an equal protection challenge, the California legislature rewrote the statute in gender-neutral terms. ${ }^{265}$ Georgia, Maryland, and Tennessee also adopted gender-neutral spousal assault laws between 1976 and $1979 .{ }^{266}$ The replacement of gender-specific discussions of wife beating with the genderneutral language of "spousal assault" during this period was also encouraged by federal law enforcement grant applications. ${ }^{267}$ (To be sure, in this era many feminists advocated the use of gender-neutral language in domestic violence policies, in the course of seeking reform of their substantive norms; lawmakers readily adopted the gender-neutral language, and moved far more

260. See, e.g., supra notes $49,55,196$ and accompanying text.

261. 429 U.S. 190 (1976).

262. Cf. Barbara Hart, State Codes on Domestic Violence: Analysis, Commentary and Recommendation, 43 FAM. CT. JUv. \& J. 3, 3 n.5 (1992) ("While it is true that as many as 5\% of those harmed by domestic violence are men, the use of gender neutral language masked the reality that those most at risk for life-imperiling violence are women."); Margaret Thornton, Feminism and the Contradictions of Law Reform, 19 INT'L J. SoC. L. 453, 460 (1991) (observing that “'spousal abuse' suggests a nonexistent neutrality" and "the term 'domestic violence' itself disguises which sex is responsible for the preponderance of the battering").

263. See supra text accompanying note 88 .

264. See Hobson v. Pow, 434 F. Supp. 362, 367 (N.D. Ala. 1977) ("No compelling, or even rational, state policy has been suggested to explain why conviction of men for assault and battery against the spouse is a cause for disqualification while the conviction of women for the same offense is not disqualifying.").

265. Equal protection litigation prompted (but did not require) the California legislature to revise the statute, codified at CAL. PENAL CODE $\$ 273.5$ (West 1988). See People v. Cameron, 53 Cal. App. 3d 786, 797 (1975) (upholding constitutionality of wife-beating statute but suggesting that California legislature might consider making statute "applicable to both spouses" and suggesting that recommended change might "afford[] some additional protection to the marital state"). See generally People v. Gutierrez, 217 Cal. Rptr. 616, 618 (Ct. App. 1985) (describing interaction between courts and legislature prompting transformation of gender-specific wife-beating statute into legislation regulating assault between spouses or cohabitants).

266. See GA. CODE ANN. \& 26-13 (Harrison 1977); 1979 Md. Laws 307, § 11F; 1976 Tenn. Pub. Acts 565 (codified at TENN. CODE ANN. § 39-602 (1981)).

267. See PLECK, DOMESTIC TYRANNY, supra note 33, at 194. 
slowly to revise the constitutive norms and procedures of their domestic violence policies. ${ }^{268}$ )

Now, when litigants challenge law enforcement policies providing lesser degrees of protection to victims of domestic violence, they have great difficulty proving that the policies are sexually discriminatory-despite the fact that it is women who are overwhelmingly the targets of assaults between intimates. ${ }^{269} \mathrm{~A}$ number of federal circuit courts have ruled that facially neutral spousal assault policies are not subject to heightened standards of review under the Equal Protection Clause (although such policies may constitute discrimination against married persons or cohabitants, subject to more deferential or "rational relation" review). ${ }^{270}$ Because such policies are

268. Cf. SuSAN BRownmiller, Against OUR Will: MEN, WOMEN AND RAPE 424-25 (1975) (recommending gender-neutral sexual assault laws). This advocacy of formally gender-neutral laws reflects the comparative logic that marked 1970s feminism. See Catharine A. MacKinnon, Reflections on Sex Equality Under Law, 100 YALE L.J. 1281, 1286 (1991); Nadine Taub \& Wendy W. Williams, Will Equality Require More Than Assimilation, Accommodation or Separation from the Existing Social Structure?, 37 RuTGERS L. REv. 825, 827 (1985); Joan C. Williams, Deconstructing Gender, 87 MiCH. L. REv. 797, 798-99 (1989). But feminist litigators sought to reform the substance, as well as the form, of domestic violence policies. Reforming only the language of the policies while leaving their underlying norms intact would not protect women from their partners' abuse. As Carrie Menkel-Meadow observes, "eliminating 'gender bias' by neutralizing husbands and wives and mothers and fathers into more equal spouses and parents (that ignored the situated differences of these roles) helped expose how formal and rhetorical equality was not entirely responsive to women's needs for substantive, actual or outcome equality." Carrie Menkel-Meadow, Mainstreaming Feminist Legal Theory, 23 PAC. L.J. 1493, 1506 (1992) (citation omitted). Indeed, some feminist activists are now concerned that policymakers' use of gender-neutral language in dealing with issues of domestic violence actually aggravates the problem by providing the appearance of reform while masking the continuing gender-specificity of the problem. In view of this concern, "many feminists [now] insist on using 'battered woman' in preference to terms such as 'spouse abuse' which are not gender specific in order to emphasize that women, not men, are almost always the target of intraspousal [sic] abuse." Martha R. Mahoney, Legal Images of Battered Women: Redefining the Issue of Separation, 90 Mich. L. REV, 1, 25 (1991); see Wini Breines \& Linda Gordon, The New Scholarship on Family Violence, 8 SigNS 490, 510-13 (1983) (criticizing ways in which language of "family violence" obscures gendered differences in manifestations of violence).

269. See supra text accompanying notes $202-05$.

270. The leading case in this area is Hynson v. City of Chester Legal Dep't, 864 F.2d 1026, 1031 (3d Cir. 1988) ("[I]f the categories used by the police in administering the law are domestic violence and nondomestic violence, this is not sufficient to raise a claim for gender-based discrimination absent a showing of an intent, purpose or effect of discriminating against women."). For other examples of circuit court decisions following Hynson, see Navarro v. Block, 72 F.3d 712 (9th Cir. 1996) (reversing district court's dismissal of equal protection claim on summary judgment because issues of material fact remained as to whether county had custom of not classifying domestic violence 911 calls as emergencies, in which case policy might fail even rational basis test); Eagleston v. Guido, 41 F.3d 865, 878 (2d Cir. 1994); Ricketts v. City of Columbia, 36 F.3d 775, 779 (8th Cir. 1994); Brown v. Grabowski, 922 F.2d 1097, 1101 (3d Cir. 1990); Watson v. City of Kansas City, 857 F.2d 690 (10th Cir. 1988). An early case that stimulated public awareness of the sexually discriminatory implications of traditional domestic violence policies, Thurman v. City of Torrington, 595 F. Supp. 1521 (D. Conn. 1984), assumed for the purpose of denying a motion to dismiss that plaintiff's allegations of gender-based discrimination were true, noting that in the vast number of cases, it is the husband who has abused his wife; but the court did observe that "[i]t may develop that the classification in the instant case is not one based on gender, but instead consists of all spouses who are victims of domestic violence-male and female." Id. at $1528 \mathrm{n} .1$; see also Balistreri v. Pacifica Police Dep't, 901 F.2d 696, 701 (9th Cir. 1990) (where complaint alleged that responding police officer "stated that he did not blame plaintiff's husband for hitting her, because of the way she was 'carrying on.' .... [s]uch remarks strongly suggest an intention to treat domestic abuse cases less seriously than other assaults, as well as an animus against abused women"), distinguished in Navarro, 72 F.3d at 717 
couched in gender-neutral terms, plaintiffs seeking to prove that the policies were animated by a sexually discriminatory purpose would have to show that they were adopted "at least in part because of, and not merely in spite of," their impact on women. ${ }^{271}$ Similar problems in proving sex discrimination occur with equal protection challenges to the doctrine of interspousal tort immunity (which, as we have seen, was couched, from the outset, in formally gender-neutral terms), ${ }^{272}$ or to the exemption for "spousal" rape, ${ }^{273}$ or to

(stating that Navarros had failed to offer any evidence of the sort of "invidious intent or motive" found in Balistreri).

Thus, a municipality defending a domestic violence policy couched in "gender neutral" terms need only show that it meets the "rational relation" test. See infra text accompanying notes 277-80.

271. See Personnel Adm'r v. Feeney, 442 U.S. 256, 279 (1979) ('“Discriminatory purpose' . . . implies more than intent as volition or intent as awareness of consequences. It implies that the decisionmaker... selected or reaffirmed a particular course of action at least in part 'because of,' not merely 'in spite of,' its adverse effects...."). In general, courts evaluating equal protection challenges to facially neutral domestic violence policies have reasoned that plaintiffs seeking to prove sex discrimination would have to show that state actors acted in accordance with Feeney's definition of discriminatory purpose. For circuit court opinions setting forth this framework, see Navarro, 72 F.3d at 712; Eagleston, 41 F.3d at 878; Ricketts, 36 F.3d at 781; Hynson, 864 F.2d at 1031; Watson, 857 F.2d at 696-97. See also Soto v. Carrasquillo, 878 F. Supp. 324, 329 (D.P.R. 1995); Smith v. City of Elyria, 857 F. Supp. 1203, 1211 (N.D. Ohio 1994); cf. Pinder v. Commissioners of Cambridge, 821 F. Supp. 376, 385 (D. Md. 1993) ("Policies that are facially neutral may trigger intermediate scrutiny when the policy has a disproportionate impact on women that results from purposeful or intentional discrimination.").

272. Most courts that have abrogated the doctrine of interspousal immunity, in whole or in part, have done so on common law grounds. See supra note 163 (discussing current state of interspousal tort immunity law). A number of courts have explicitly rejected claims that the doctrine of interspousal immunity should be abrogated on equal protection grounds. In Alfree v. Alfree, 410 A.2d 161 (Del. 1979), the Delaware Supreme Court stated that "based on current precedent, there appears to be no Federal constitutional limitation on the interspousal immunity doctrine." Id. at 163. Although Alfree was overruled in Beattie v. Beattie, 630 A.2d 1096, 1100 (Del. 1993), the Beattie court abrogated the doctrine on common law grounds only. In Nicpon ex rel. Urbanski v. Nicpon, 495 N.E.2d 1193 (Ill. App. Ct. 1986), the court rejected plaintiff's argument that the Illinois interspousal immunity statute (applicable to negligent torts only) should be analyzed under doctrines of intermediate scrutiny, and held that the statute survived equal protection challenge under standards of "minimum scrutiny." Id. at 1196; see also Locklair v. Locklair, 256 F. Supp. 530,533 (D.S.C. 1966) (upholding doctrine and reasoning that "there is no discrimination nor denial of equal protection of the laws ... inasmuch as the Georgia law applies equally to husbands as well as to wives"); State Farm Mut. Auto. Ins. Co. v. Palmer, 463 N.E.2d 129, 131 (III. App. Ct. 1984) (holding that interspousal immunity doctrine is abrogated as to intentional torts only, and that interspousal immunity is not unconstitutional on either due process or equal protection grounds); cf. Paiewonsky v. Paiewonsky, 446 F.2d 178, 182 (3d Cir. 1971) (holding that "legislative interest in promoting domestic tranquility is sufficiently compelling" and that "the immunity doctrine ... has a reasonable relationship to the interest sought to be furthered by it").

Several courts have held that interspousal immunity fails even the rational basis test. See, e.g., Moran v. Beyer, 734 F.2d 1245, 1248 (7th Cir. 1984); Jones v. Jones, 376 S.E.2d 674, 675 (Ga. 1989). Some courts, in abrogating the doctrine on common law grounds, have added a single-sentence comment about equal protection considerations. See, e.g., Burns v. Burns, 518 So. 2d 1205, 1211 (Miss. 1988); Price v. Price, 732 S.W.2d 316, 320 (Tex. 1987).

273. See Robin West, PROGRessive Constitutionalism: ReCONSTRUCTING the FourteEnTH AMENDMENT 62 (1994) (" $[\mathrm{A}]$ court conceivably could decide that, ancient history notwithstanding, a [marital rape] statute recently cleansed of gender-specific language is freed of its misogynistic heritage and that its recent legislative history provides the sole source of its constitutionality."); West, supra note 214, at 46-48, 63-68 (reviewing arguments for and against constitutionality of marital rape laws, and discussing difficulty of challenging marital rape laws, especially when they are redrafted in gender-neutral terms). For an argument that both gender-specific and gender-neutral marital rape laws discriminate against women and violate the Equal Protection Clause, see Note, To Have and to Hold: The Marital Rape Exemption and the Fourteenth Amendment, 99 HARV. L. REV. 1255, 1267-72 (1986). 
rules giving "spouses" rights to the value of labor performed in the household. ${ }^{274}$

In this way, modern doctrines of equal protection are effacing the gender(or race-) specific antecedents of state policies ${ }^{275}$ that in their current, facially neutral form may well continue to enforce relations of gender or racial inequality. While modern equal protection law has served to disestablish certain forms of status-enforcing state action, in many cases, the changes equal protection doctrines effected were at best superficial. ${ }^{276}$

Consider the domestic violence policies we have examined. The threat of equal protection litigation prompted the deletion of gender-specific references from the law; once "sanitized" in this way, such policies have become exceedingly difficult to challenge with existing constitutional tools, even when

274. In Borelli v. Brusseau, 16 Cal. Rptr. 2d 16 (Ct. App. 1993), an equal protection challenge to a gender-neutral version of the old common law doctrine of marital service was summarily rejected on the grounds that the gender neutrality of the rule cleansed it of any historical taint:

We agree with the dissent that no rule of law becomes sacrosanct by virtue of its duration, but we are not persuaded that the well-established rule that governs this case deserves to be discarded. If the rule denying compensation for support originated from considerations peculiar to women, this has no bearing on the rule's gender-neutral application today.

Id. at 20; see also Siegel, Modernization, supra note 38, at 2196-99 (discussing Borelli).

275. Obviously, domestic violence policies were not the only aspects of family law affected by the emerging sex discrimination case law of the 1970s. For example, even before the Court held in Orr v. Orr, 440 U.S. 268, 283 (1979), that gender-based alimony statutes violated the Equal Protection Clause, "about 40 states had already 'desexed' alimony and authorized its award, under appropriate circumstances, to either spouse." Doris Jonas Freed \& Henry H. Foster, Jr., Divorce in the Fifty States: An Overview, 14 FAM. L.Q. 229,252 (1981). In the years after Orr, the remaining states followed suit. See id. at 253.

In this period, some states adopted statutes that eliminated gender distinctions from whole bodies of law. See, e.g., id. (describing New York statute adopted in 1980 that removed gender distinctions from "Domestic Relations Law, Family Court Act, and other existing statutes"); Note, The Significance of Stokes v. Stokes: An Examination of Property Rights upon Divorce in Georgia, 16 GA. L. REV. 695, 705-06 n.55 (1982). The Note discusses $1979 \mathrm{Ga}$. Laws 466, which provided in pertinent part:

"It is the intent of this Act to revise and modernize certain laws of this State which relate to intrafamilial duties, rights and obligations, including laws relating to divorce, alimony, support of minors, husband and wife, parent and child, enforcement of support, and related matters, so as to comply with those standards of equal protection under the law announced in the United States Supreme Court decision in the case of Orr v. Orr ...."

276. Making a race- or gender-specific law facially neutral may have very different consequences, depending on a variety of factors, including: the nature of the law, the nature of the social practice it regulates, and the ways in which the regulated practice allocates dignitary and/or material privileges. While the topic is far too vast to explore in the present context, several examples should suffice to illustrate my point. Removing racial distinctions from a school assignment policy may facilitate the integration of a school system, but will have less of an integration effect if the policy endorses "neighborhood" school assignments under conditions of residential segregation. Removing gender distinctions from a law conscripting persons for military service will facilitate the integration of the armed forces, but will have less of an integration effect if the conscription policy specifies height, weight, and strength requirements that relatively few women can meet. Removing gender distinctions from the law of rape will not much alter the social conditions under which rapes are practiced; nor will removing gender distinctions from domestic violence law much alter the practice of "spouse beating." Making such laws facially neutral does not alter the constraints on men who assault women; rather, it extends the scope of the prohibition to include women. Presumably this reform will have a marginal deterrent effect on women's conduct, but none on men's conduct. Nor is it clear what "symbolic" message is communicated by making gender-specific laws regulating gender-salient practices into gender-neutral laws. To disrupt the subordinating practice in these cases, it is necessary to alter the norms of the laws that regulate it. In short, formal equality will disrupt certain subordinating practices, and leave others relatively undisturbed-possibly even masking the nature of the harm they are inflicting. 
their historically rooted norms remain intact and substantially unquestioned. Under the case law we have just surveyed, a municipality defending a facially neutral domestic violence policy against an equal protection claim need only show that the policy is rationally related to some legitimate state purpose and was not adopted "because of" its "adverse effects" on women. To say the least, this showing does not require municipalities to make significant changes in the structure of their policies-even if the facially neutral policies continue to treat victims of assaults by intimates differently than other victims of assault. In Siddle v. City of Cambridge, ${ }^{277}$ the court found that the city's proffered justifications did in fact pass the rational basis test:

The state puts forth several justifications for any differences that may exist. These justifications fulfill the rational basis test, and reach the level of an important state objective. The first is that the criminal area may not be the best place to resolve marital problems of this sort. The government needs flexibility so that all of its resources, including mental health agencies, can rectify the situation. Often criminal sanctions alone are ineffective. Moreover, domestic violence situation [sic] are different from other forms of criminal behavior in their complex emotional causes of behavior. . . . The government need not treat cases as the same, because it would be unproductive, and possibility counter-productive, to do so. ${ }^{278}$

The justifications accepted by this court as satisfying the rational relation (and even intermediate scrutiny) test should be quite familiar. The reasons supplied are conventional expressions of the discourse of affective privacy, which has been used to justify criminal law policies on domestic violence since the Progressive Era ${ }^{279}$-reasons for affording informal immunity to assaults between intimates that would not obtain in other contexts. The analytical framework of equal protection cases such as these merely serves to rationalize a body of laws whose normative roots can be traced to the ancient doctrine of marital chastisement. For close to two decades now, the modern feminist movement has protested the inadequacy of domestic violence policies but, in the course of this work, has received considerably less assistance from the Constitution's promise of equal protection of the laws than the lineage of the policies would seem to warrant. ${ }^{280}$

277. 761 F. Supp. 503 (S.D. Ohio 1991).

278. Id. at 512 (emphasis added).

279. See supra text accompanying notes 192-96 (discussing rise of criminal law policies that treated marital violence in therapeutic paradigm premised on assumption that "domestic trouble cases are not criminal in a legal sense").

280. An early equal protection case, Thurman v. City of Torrington, 595 F. Supp. 1521 (D. Conn. 1984), prompted public awareness of the inadequate protections afforded women by traditional domestic violence policies. See Carolyne R. Hathaway, Comment, Gender Based Discrimination in Police Reluctance to Respond to Domestic Assault Complaints, 75 GEO. L.J. 667, 669 (1986) ("Thurman v. City of Torrington was the first reported case in which a court held that police conduct treating victims of domestic violence 
There are certain modifications to equal protection doctrine that could make it supple enough to police for bias in the new forms of "facially neutral" state action it has helped bring into being. For instance, the Court might revise the doctrinal criteria that define race- and sex-based state action for purposes of triggering heightened scrutiny. ${ }^{281}$ Given the lineage of "spousal" assault policies, why should the mere use of gender-neutral language immunize the policies from heightened scrutiny? Or the Court might revise the muchcriticized doctrines of discriminatory purpose that plaintiffs must use to challenge facially neutral policies and practices. ${ }^{282}$ Given the history of marital violence regulation, why must a plaintiff show that a facially neutral spousal assault policy was adopted "because of" its "adverse effects" on women? This requirement seems especially perverse in an "equal rights" era, when policymakers conventionally supply "legitimate, nondiscriminatory" reasons for their actions.

Unfortunately, as currently constituted, the Court shows scant interest in revising equal protection doctrines of heightened scrutiny and discriminatory purpose. This body of constitutional law once served to dismantle statusenforcing state action, but, because of its very success in precipitating the reform - and modernization - of status-enforcing state action, the doctrines now serve to rationalize, rather than scrutinize, the new, facially neutral forms of status-enforcing state action they have helped bring into being.

Of course, the Court's interpretation of the Equal Protection Clause still allows advocates to seek legislative reform of facially neutral policies that perpetuate historically rooted status relationships. ${ }^{283}$ To illustrate the possibilities and limitations of such an approach, I will close this Article with a brief examination of the new Violence Against Women Act, ${ }^{284}$ which, in an attempt to effectuate constitutional mandates of equal protection, creates a federal civil rights cause of action for victims of gender-motivated violence.

differently than other assault victims constitutes gender based discrimination violative of the equal protection clause."). In Torrington, the court assumed for the purpose of denying a motion to dismiss that the plaintiff's allegations of sex discrimination were true, while observing that "[i]t may develop that the classification in the instant case is not one based on gender, but instead consists of all spouses who are victims of domestic violence-male and female." 595 F. Supp. at 1528 n.1. In litigation after Torrington, municipalities have generally been able to reduce their risk of adverse judgments by couching domestic violence policies in gender-neutral terms. See supra note 270 and accompanying text.

281. These criteria are formal, rather than historical or sociological. See, e.g., Personnel Adm'r v. Feeney, 442 U.S. 256 (1979) (characterizing veterans' preferences for civil service employment as "facially neutral" policies); Geduldig v. Aiello, 417 U.S. 484 (1974) (characterizing rules goveming pregnancydisability policy as "facially neutral"); see also Siegel, Reasoning from the Body, supra note 119, at 354 n.373 (discussing question as it bears on equal protection challenges to abortion policies); id. at 360 n.396.

282. See, e.g., LAURENCE H. TRIBE, AMERICAN ConstituTIONAL LAW $\S 16-21$, at 1514-15 (2d ed. 1988); Lawrence, supra note 256, at 317; David A. Strauss, Discriminatory Intent and the Taming of Brown, 56 U. CHI. L. REv. 935, 1014 (1989).

283. Cf. West, supra note 214 , at 76-79 (proposing federal civil rights legislation that would, inter alia, abolish marital rape exemption).

284. Pub. L. No. 103-322, § 40302, 108 Stat. 1941 (1994) (codified as amended at 42 U.S.C.A. $\S 13981$ (West 1995)). 
The new legislation has the capacity to alter the adjudication of domestic assault cases. Whether and how it will do so is a matter still to be determined by the courts-which to date have not yet applied the statute.

\section{Discourses of Affective Privacy Today: Interpreting the Violence Against Women Act}

The Violence Against Women Act (VAWA) was enacted to provide resources to local authorities attempting to combat the types of violence women commonly suffer-in particular, assaults by spouses or other intimate partners and acts of rape. Concerned that states had historically failed to provide women adequate protection from violent, sexualized assault, and that little protection was provided by existing anti-bias crime laws, the Act's proponents also sought to create a federal civil rights remedy for victims of gender-motivated violence. ${ }^{25}$ The civil rights remedy contained in Title III of the bill ${ }^{286}$ was intended to effectuate federal constitutional guarantees of equal protection. ${ }^{287}$ But the proposed civil rights remedy was soon mired in controversy, drawing opposition in Congress that for some time threatened to prevent the Title's passage. Critics of Title III did not object to providing women relief from gender-motivated violence; instead they complained that the new civil rights remedy would federalize matters that had historically been regulated by the states. ${ }^{288}$ While opponents of Title III did not succeed in blocking its passage, they did play a role in shaping the civil rights remedy that Congress ultimately enacted into law.

A brief review of the controversy attending the enactment and interpretation of VAWA's civil rights remedy provides a fitting place to conclude this Article for at least two reasons. First, a strong case can be made that the controversy over the civil rights remedy reflects the continuing power of certain modes of reasoning about marital violence that began in the

285. See S. REP. No. 138, 103d Cong., 1st Sess. 48-50 (1993).

286. The civil rights remedy appeared in Title III of the first version of VAWA, S. 2754, 101st Cong., 2d Sess. (1990), and remained in subsequent versions of the bill until its enactment as Pub. L. No. 103-322, tit. IV, subtit. C., $\$ 40302,108$ Stat. 1941 (1994) (codified at 42 U.S.C.A. $\S 13981$ (West 1995)).

287. See S. REP. No. 138 , supra note 285 , at 51 :

Title III's civil rights provision simply makes explicit what the Supreme Court has already held: that violence motivated by gender is not an individual crime or a personal injury, it is a form of discrimination. This country has been using Federal civil rights laws to fight discriminatory violence for 120 years. Title III is a logical extension of this tradition.

....

State laws do not provide, and by their nature cannot provide, a national antidiscrimination standard. While traditional criminal charges and personal injury suits focus on the harm to the individual, a civil rights claim redresses an assault on a commonly shared ideal of equality. This was Congress's understanding over 120 years ago when it passed the first civil rights laws against violent discrimination; it remains true today.

Congress viewed the statute as an exercise of its powers under Section 5 of the Fourteenth Amendment, as well as the Commerce Clause. See infra note 304 and accompanying text.

288. See infra text accompanying notes 291-99. 
nineteenth century. Second, even those readers who remain unpersuaded that discourses of affective privacy have shaped the controversy over VAWA's civil rights remedy will be able to appreciate how interpretive conflicts over the provision have prompted the renewed modernization of discourses of gender status. In short, the controversy over VAWA's civil rights remedy illustrates that, even today, the rules and rhetoric of gender status relations continue to evolve in the face of recent civil rights initiatives. In the following sections, I recount briefly the controversy surrounding the civil rights remedy, and then demonstrate how it enacts, both substantively and methodologically, the modernization dynamic explored throughout this Article.

\section{VAWA's Civil Rights Remedy for Gender-Motivated Violence}

VAWA's civil rights remedy broke new ground. Title III analyzed violence against women as a form of sex discrimination. ${ }^{289}$ It was premised on the view that "'crimes motivated by the victim's gender constitute bias crimes in violation of the victim's right to be free from discrimination on the basis of gender," that "'existing bias and discrimination in the criminal justice system often deprives victims of gender-motivated crimes of equal protection of the laws and the redress to which they are entitled,"' and that "'victims of gender-motivated violence have a right to equal protection of the laws, including a system of justice that is unaffected by bias or discrimination and that, at every relevant stage, treats such crimes as seriously as other violent crimes." 290 The bill provided victims of rape and domestic violence protection under federal civil rights laws which heretofore they had not had.

While VAWA's civil rights remedy drew many critics, not one critic of the civil rights remedy disparaged the statute's goal of protecting women from rape and domestic violence. Rather, critics argued that creating a federal cause of action to vindicate such injuries usurped a traditional regulatory interest of the states and threatened to flood the federal courts with cases the federal judiciary was ill-equipped to handle. ${ }^{291}$

289. For example, S. 15 defined "crime of violence motivated by gender" as "any crime of violence, as defined in this section, including rape, sexual assault, sexual abuse, abusive sexual contact, or any other crime of violence committed because of gender or on the basis of gender." S. 15, 102d Cong., 1st Sess. $\S 301$ (d)(1) (1991). After mark-up, the bill defined "crime of violence motivated by gender" as "any crime of violence [as defined in 18 U.S.C. $\S 16$ ] committed because of gender or on the basis of gender."” S. REP. No. 197, 102d Cong., 1st Sess. 28 (1991) (quoting S. 15, \$ 301(d)(1), as amended). For the current language of the statute, see infra text accompanying note 301.

290. S. REP. No. 197 , supra note 289 , at $27-28$ (quoting S. 15 , \& 301(a), as amended); see also S. REP. No. 138, supra note 285 , at 51 ("[V]iolence motivated by gender is not an individual crime or a personal injury, it is a form of discrimination.").

291. While there were other constitutional concerns raised about the civil rights remedy, during the 102d Congress criticism began "to coalesce around the theme of federalization." Victoria Nourse, The Violence Against Women Act: A Legislative History 37 (Sept. 6, 1995) (unpublished manuscript, on file with author). 
For example, in January of 1991, the Conference of Chief Justices announced its opposition to Title III on the grounds that the provision could "cause major state-federal jurisdictional problems and disruptions in the processing of domestic relations cases in state courts." ${ }^{292}$ The state chief justices reasoned that the "right will be invoked as a bargaining tool within the context of divorce negotiations and add a major complicating factor to an environment which is often acrimonious as it is." ${ }^{293}$ They continued:

The issue of inter-spousal litigation goes to the very core of familial relationships and is a very sensitive policy issue in most states. It does not appear that S. 15 is meant to plunge the federal government into this complex area which has been traditionally reserved to the states, but this might well be the result if the current language stands. It should be noted that the volume of domestic relations litigation in state courts is enormous.

It should also be noted that the very nature of marriage as a sexual union raises the possibility that every form of violence can be interpreted as gender-based. ${ }^{294}$

Observing that "the federal cause of action ... . would impair the ability of state courts to manage criminal and family law matters traditionally entrusted to the states," the Conference of Chief Justices resolved that the provision should be eliminated. ${ }^{295}$

By September of 1991, the Judicial Conference of the United States joined the Conference of Chief Justices in opposing Title III. The federal judges complained that the new civil rights remedy would burden an already overcrowded federal docket; they also echoed the concern voiced by the state judges that the civil rights cause of action "will be invoked as a bargaining tool within the context of divorce negotiations [complicating] an environment which is often acrimonious as it is." ${ }^{296}$ The Judicial Conference then observed that the "subject of violence based on gender and possible responses is extremely complex," and promised to work with Congress "to fashion an appropriate response to violence directed against women." ${ }^{.297}$ It was in this

292. Crimes of Violence Motivated by Gender: Hearing Before the Subcomm. on Civil and Constitutional Rights of the House Comm. on the Judiciary, 103d Cong., 1st Sess. 80 (1993) [hereinafter Crimes of Violence] (statement by Conference of Chief Justices on S. 15, Violence Against Women Act of 1991, adopted by the State-Federal Relations Committee of the Conference of Chief Justices at meeting in Scottsdale, Arizona on Jan. 31, 1991).

293. Id.

294. Id. at $80-81$ (emphasis added).

295. Id. at 83-84.

296. Id. at 75 (quoting Report of the Proceedings of the Judicial Conference of the United States, Sept. 23-24, 1991, at Asheville, North Carolina).

297. Id. In 1993, after certain modifications were made to the civil rights remedy, the Judicial Conference changed from a stance of opposition to one of taking "no position" on the provision. See $i d$. at 73 (Report of the Proceedings of the Judicial Conference of the United States, Mar. 16, 1993, Washington, D.C.). 
context that Chief Justice Rehnquist raised his objections to Title III, complaining that the "new private right of action [is] so sweeping that the legislation could involve the federal courts in a whole host of domestic relations disputes. ${ }^{\text {"298 }}$

Facing opposition to Title III, VAWA's original sponsor, Senate Judiciary Committee Chairman Senator Joseph Biden, joined with Senator Orrin Hatch (then ranking minority member of the Committee) to draft a version of the civil rights remedy that could allay the federalism concerns voiced by the bill's critics. In order to defer to the states' traditional role in regulating matters of marriage and divorce and to shield federal dockets from overcrowding, Senator Hatch sought to limit the range of assaults that might fall within the ambit of Title III's protections. ${ }^{299}$

The statute that ultimately emerged from these negotiations provides that, "All persons within the United States shall have the right to be free from crimes of violence motivated by gender." ${ }^{300}$ It then defines "motivated by gender" as follows: "[T]he term 'crime of violence motivated by gender' means a crime of violence committed because of gender or on the basis of gender, and due, at least in part, to an animus based on the victim's gender." ${ }^{301}$ Victims of gender-motivated violence are entitled to compensatory and punitive damages, as well as declaratory and injunctive relief. ${ }^{302}$ The Act requires courts to determine which instances of rape or battery the civil rights remedy covers on a case-by-case basis. (It provides: "Nothing in this section entitles a person to a cause of action ... for random acts of violence unrelated to gender or for acts that cannot be demonstrated, by a preponderance of the evidence, to be motivated by gender ...."303) Congress declared that it was enacting the new civil rights remedy pursuant to its power under Section 5 of the Fourteenth Amendment as well as its power to regulate commerce. ${ }^{304}$

The same federalism concerns that critics raised in opposition to the civil rights remedy presumably will shape its interpretation, as courts attempt to

298. See Rehnquist, supra note 216 , at 1,3 .

299. See Nourse, supra note 291, at 51-52; see also Sally F. Goldfarb, Gender-Motivation and the Violence Against Women Act: A New Chapter in Federal Civil Rights Law 23-24 (unpublished manuscript, on file with author).

300. 42 U.S.C.A. $\$ 13981$ (b) (West 1995).

301. Id. \& 13981(d)(1). Senate Report No. 138 observes:

For clarity, section 302 (d)(1) has been revised from previous versions of the act. Although discriminatory motivation has always been required by the act, this section has been amended to require that crimes of violence be "due, at least in part, to an animus based on the victim's gender." This new language elucidates the committee's intent that a victim alleging a violation under this section must have been targeted on the basis of his or her gender. The defendant must have had a specific intent or purpose, based on the victim's gender, to injure the victim.

S. REP. NO. 138 , supra note 285 , at 64 .

302. See 42 U.S.C.A. $\$ 13981$ (c) (West 1995).

303. Id. $\S 13981(\mathrm{e})(1)$.

304. See id. § 13981(a) (citing U.S. CoNST. amend. XIV, § 5 and U.S. CoNST. art. I, § 8). 
identify which acts of violence are "gender-motivated" within the meaning of the act, and which are not. But how is it that courts are to determine which acts of rape and domestic violence are "gender-motivated" and which are not? ? $^{305}$ Here the meaning given the phrase "an animus based on the victim's gender" will be pivotal in the interpretation of the new civil rights remedy. Will courts construe "animus" to mean something akin to "purpose" or "malice"? Those, such as Senator Hatch, who seek a more restrictive construction of the civil rights remedy will argue that animus means malice, while those more receptive to a federal role in remedying violence against women will construe animus as a form of purpose. To appreciate how the interpretive struggle will unfold in more concrete terms, it is helpful to consider how Senator Hatch described for the New Republic the injuries the statute covers:

"We're not opening the federal doors to all gender-motivated crimes. Say you have a man who believes a woman is attractive. He feels encouraged by her and he's so motivated by that encouragement that he rips her clothes off and has sex with her against her will. Now let's say you have another man who grabs a woman off some lonely road and in the process of raping her says words like, 'You're wearing a skirt! You're a woman! I hate women! I'm going to show you, you woman!' Now, the first one's terrible. But the other's much worse. If a man rapes a woman while telling her he loves her, that's a far cry from saying he hates her. A lust factor does not spring from animus. $\$ 306$

\section{VAWA: Rule of Love Redux}

In the controversy over the scope of VAWA's civil rights remedy, we can see the law of intimate assault undergoing modernization. The bill's proponents sought to provide women relief from intimate assault, treating it as a form of sex discrimination-as "gender-motivated violence." The bill's opponents raised a series of federalism objections to the cause of action, first resisting and then accepting with reservations, the antidiscrimination framework of the statute. Although both groups now espouse a commitment to ending gendermotivated violence, their understanding of what that violence is differs. Accordingly, there will be a struggle over the scope of the civil rights remedy,

305. The inquiry presupposes that acts of rape and domestic violence can be gender-motivated like acts of arson can be racially motivated: Some acts of arson may result from discriminatory animus, while others may not. But a strong case can be made that acts of rape and domestic violence are better analogized to white-on-black lynching-a practice employed within a historically specific status regime by statussuperiors to dominate and subdue those they considered their status-inferiors. If rape and domestic violence are more akin to lynching than arson, then it makes little sense to attempt to determine which acts of rape and domestic violence spring from a discriminatory or status-based animus and which do not.

306. Ruth Shalit, Caught in the Act, New Republic, July 12, 1993, at 12, 14 (emphasis added) (quoting Senator Orrin Hatch). 
focusing on the meaning of "crime of violence motivated by gender." What is " a crime of violence committed because of gender or on the basis of gender, and due, at least in part, to an animus based on the victim's gender"? ${ }^{307}$ The answer to this question will depend in part on the weight given the federalism arguments raised by critics of the civil rights remedy. If we examine these federalism objections, it is possible to see how they gain persuasive power as they draw on the discourse of affective privacy, using it as a basis for restricting the meaning of "gender motivated violence," and thus the protections afforded women by the Act. In short, the struggle over VAWA's civil rights remedy resembles the struggle over the tort provisions of the married women's property acts, not only in structure, but in substance: Federalism objections to the civil rights remedy acquire persuasive power as they draw on the traditional modes of reasoning about intimate assault.

There are several levels at which we can discern the discourse of affective privacy operating in disputes over the civil rights remedy. The first involves the characterization question on which the whole federalism dispute hinges. Suppose a man rapes, beats, or knifes his wife. Does a woman's ability to secure relief for such injuries bear on her status as an equal citizen of this nation? Or is this question properly of local concern, implicating matters of family law and criminal law, but not matters of sex discrimination or equal protection? The assertion that VAWA interferes with traditional state regulatory concerns implicitly, and explicitly, adopts the latter view. In these objections the issue of gender bias that prompted VAWA's enactment recedes from view, and sexualized assault appears as a problem concerning "family matters." As Chief Justice Rehnquist succinctly expressed his objections to the civil rights remedy, the statute "could involve the federal courts in a whole host of domestic relations disputes." ${ }^{\text {"308 }}$ When the Conference of Chief Justices asserted that " $[t]$ he issue of inter-spousal litigation goes to the very core of familial relationships and is a very sensitive policy issue in most states," ${ }^{309}$ it was characterizing intimate assaults in the idiom of the interspousal immunity doctrine examined in Part III of this Article. It is only by virtue of this historical tradition that significant audiences of lawmakers and jurists find it at all persuasive to characterize acts of rape or battery as matters of "domestic relations" law, or the stuff of "acrimonious" "divorce negotiations," or as "sensitive policy issue[s]," or "matters traditionally entrusted to the states." ${ }^{\text {"310 }}$ In short, it is because critics of the civil rights remedy are still reasoning within the common law tradition the statute seeks

307. See supra note 301 and accompanying text.

308. See Rehnquist, supra note 216 , at 1,3 (emphasis added).

309. Crimes of Violence, supra note 292, at 80-81 (emphasis added).

310. See supra text accompanying notes $292-95$. This tradition of reasoning about intimate assault is so powerful that it also deflects attention from the many forms of nonmarital assault the statute covers. 
to disestablish that they can characterize VAWA as intruding in regulatory domains that are not properly of federal concern.

Just as history plays a role in characterizations of VAWA's regulatory objectives, it also plays a role in the federalism story that characterization sets in motion. Under our system of federalism, states have historically regulated matters of family law. And in federalism claims about the family, that history typically assumes dispositive weight: Congress should not disturb the allocation of regulatory responsibilities that this nation has forged under the federal constitutional system. But as the paradigm case of slavery teaches us, before we defer to the weight of tradition in such matters, we need at least to consider the normative underpinnings of that initial allocation of federal and state regulatory responsibilities. In the case of family law, uncritical perpetuation of past practice is likely to prove normatively problematic for reasons that, upon reflection, are not terribly surprising: Federalism discourses about the family grew up in intimate entanglement with the common law of marital status. Indeed, as we examine the claim that marriage is a state-law concern, it begins to appear that federalism discourses about marriage bear strong family resemblances to common law privacy discourses about marriage, and in some instances are even direct descendants of the discourse of affective privacy.

The claim that marriage is properly a matter of state-law concern has important roots in nineteenth-century deliberations of Congress and the Court. ${ }^{311}$ One prominent source of this notion is the "domestic-relations exception" to federal diversity jurisdiction, announced in the 1858 case of Barber v. Barber. ${ }^{312}$ But if we read Barber closely, it turns out that the claim that husband and wife cannot be diverse for federal jurisdictional purposes was itself an outgrowth of the doctrine of marital unity. Under the common law of marital status, a wife's domicile was her husband's; thus, following the logic of the common law, the Supreme Court reasoned that husband and wife could not be diverse (i.e., citizens of different states) for federal jurisdictional purposes. Both the majority and dissenting opinions in Barber affirm that

311. While states regulated family law during the eighteenth century, the question of the federal government's power to regulate the field was not, to my knowledge, much discussed in this era. See Sylvia A. Law, The Founders on Families, 39 U. FLA. L. ReV. 583, 586 (1987) ("Virtually nothing in the original constitutional debates directly addresses the situation of women and families."). Michael Grossberg observes that state "judicial dominance of domestic relations grew out of an abiding commitment to local control that lay at the heart of nineteenth-century American family law ... [and] stemmed from the deep-seated republican aversion to centralized government in general." GROSSBERG, supra note 237, at 295.

312. 62 U.S. 582, 584 (1858) (announcing that "[w]e disclaim altogether any jurisdiction in the courts of the United States upon the subject of divorce, or for the allowance of alimony"). Judith Resnik offers a detailed account of the domestic-relations exception to federal diversity jurisdiction in her study of the gendered premises of federal jurisdiction. See Judith Resnik, "Naturally" Without Gender: Women, Jurisdiction, and the Federal Courts, 66 N.Y.U. L. REV. 1682, 1739-50 (1991). 
proposition. ${ }^{313}$ The Barber dissent then goes on to translate that precept of marital unity doctrine into the discourse of affective privacy:

It is not in accordance with the design and operation of $a$ Government having its origin in causes and necessities, political, general, and external, that it should assume to regulate the domestic relations of society; should, with a kind of inquisitorial authority, enter the habitations and even into the chambers and nurseries of private families, and inquire into and pronounce upon the morals and habits and affections or antipathies of the members of every household. .. The Federal tribunals can have no power to control the duties or the habits of the different members of private families in their domestic intercourse. This power belongs exclusively to the particular communities of which those families form parts, and is essential to the order and to the very existence of such communities. ${ }^{314}$

This passage from Barber should sound somewhat familiar. It discusses the role of the federal and state government in regulating domestic relations much as the Rhodes opinion discussed the role of state government and "family government" in regulating domestic relations. ${ }^{315}$ As this passage from Barber might suggest, much of the idiom used to designate marriage as a "local" matter within discourses of federalism either echoes or can be traced to the common law doctrines of marital privacy of the sort examined in Part III of this Article. ${ }^{316}$

The conviction that marriage is a matter for states to regulate can also be traced to efforts to protect the common law of marital status from reform in the aftermath of the Civil War, an era when Congress was first beginning to exercise its new power to regulate race discrimination in the states. As several historians have recounted, Congress sought to draft the Fourteenth Amendment and the 1866 Civil Rights Act so as to protect emancipated slaves from race

313. See 62 U.S. at 592; id. at 600-01 (Daniel, J., dissenting).

314. Id. at 602 (Daniel, J., dissenting) (emphasis added).

315. See supra text accompanying notes 133-38. To recall, in Rhodes, the North Carolina Supreme Court observed that

however great are the evils of ill temper, quarrels, and even personal conficts inflicting only temporary pain, they are not comparable with the evils which would result from raising the curtain, and exposing to public curiosity and criticism, the nursery and the bed chamber. Every household has and must have, a government of its own, modelled to suit the temper, disposition and condition of its inmates.

State v. Rhodes, 61 N.C. (Phil. Law) 453, 457 (1868).

316. For a recent domestic-relations-exception case quoting the privacy language of Barber's dissent, see Ankenbrandt v. Richards, 504 U.S. 689, 702 (1992):

[E]nforcement of ... validly obtained [divorce or alimony] orders does not "regulate the domestic relations of society" and produce an "inquisitorial authority" in which federal tribunals "enter the habitations and even into the chambers and nurseries of private families, and inquire into and pronounce upon the morals and habits and affections or antipathies of the members of every household."

Id. (quoting Barber, 62 U.S. at 602 (Daniel, J., dissenting)). 
discrimination while shielding from reform certain features of gender status law: specifically, restrictions on woman suffrage and the marital status doctrines that, for example, prohibited wives from forming contracts, filing suit, or otherwise exercising legal capacity independently of their husbands. ${ }^{317}$

Thus, the notion that family law is a matter of state, not federal, concern can be traced to gendered domicile rules of the common law of marital status, as well as to efforts to preserve other gender-specific aspects of the common law of marital status-law that is now deemed unconstitutional. ${ }^{318}$ In addition, as our examination of Barber reveals, the claim that marriage is a state-law concern acquires persuasive force at least in part because it draws upon discourses of affective privacy that grew out of the doctrine of marital

317. Ellen DuBois has provided a detailed account of the controversies about woman suffrage precipitated by the drafting of the Fourteenth Amendment. See DuBors, supra note 36, at 53-78. Similarly, Amy Stanley has described the debates about marital status law precipitated by enactment of the 1866 Civil Rights Act, which barred discrimination on the basis of race in laws governing the right to make and enforce contracts, the right to sue and to participate in litigation, and laws concerning the security of persons and property. See Amy Dru Stanley, Conjugal Bonds and Wage Labor: Rights of Contract in the Age of Emancipation, 75 J. AM. HIST. 471, 477-81 (1988). Stanley observes:

Opponents of the radical program of Reconstruction challenged every assertion that the link between freedom and contract justified federal interference with local law. Not only did they raise the specter of black suffrage; they conjured up equally dire images of federal regulation of marriage and sexuality. Radicals like Sumner and Thaddeus Stevens took pains to dissociate the project of emancipation from questions of gender. Yet the issues remained joined-not only by the arguments of states' rights men and feminists but also by the legal codes of southem states that classified master and slave and husband and wife as parallel parts of the law of domestic relations.

Id. at 477. Opponents of Reconstruction argued that "[a]s 'domestic relations' . . . both slavery and marriage were governed exclusively by state law," and that the 1866 Civil Rights Act "encroached on state codes that ordered relations between the races and fixed the terms of the marriage contract." Id. at 479. Republican proponents of Reconstruction responded by limiting the compass of emancipation, steadfastly denying that it altered either the institution of marriage or the status of wives. Rather, they drew a sharp line between race and gender distinctions at law and qualified the guarantee of "civil rights" to bar only discrimination based on "race, color or previous condition of slavery."

Id. In this spirit, one Republican pointed out to Congress that the Act permits the States to say that the wife may not testify, sue, or contract. It makes no law as to this. ... Your State may deprive women of the right to . . . contract ... [b]ut if you do so, or do not so as to one race, you shall treat the other likewise. . . . [I]f you do discriminate, it must not be "on 'account' of race, color, or former condition of slavery."

CONG. GlOBE, 39th Cong., 1st Sess. 1293 (1866) (statement of Rep. Shellabarger); see also Stanley, supra, at 479-80 (quoting Shellabarger). See generally Patricia Lucie, On Being a Free Person and a Citizen by Constitutional Amendment, 12 AM. STUD. 343, 350, 349-56 (1978) (describing efforts of Reconstruction Congress to change law of racial status without changing law of gender status, and noting that in this period Republicans "judged that when a measure went far enough to limit a state's freedom to legislate on married women's property, family law, marriage, or divorce it went too far in altering the balance between the federal govemment and the states"); Siegel, Home As Work, supra note 38, at 1148 n.271 (reviewing efforts of Reconstruction Congress to assert federal authority over questions of race discrimination, while leaving to the states prerogative to regulate matters concerning questions of women's citizenship, such as suffrage and marital status law).

318. See Orr v. Orr, 440 U.S. 268 (1979) (striking down gender-based alimony statute on federal equal protection grounds); see also supra note 275 and accompanying text (describing how equal protection decisions during 1970 s prompted states to replace gender-specific family law rules with gender-neutral family law rules). 
unity. Claims about federal intervention in domestic relations reiterate more generalized anxieties about governmental interference in family life. ${ }^{319}$

Thus far I have shown how traditions of common law reasoning have shaped federalism claims about regulating domestic relations raised by critics of VAWA's civil rights remedy. But the discourse of affective privacy plays another important role in disputes over the scope of the civil rights remedy, supplying normative criteria for identifying the types of assaults to which the cause of action applies. Here historical connection is by no means as direct, and yet some notion of affection in intimate relationships seems to be regulating intuitions about what kinds of sexualized assaults are "gendermotivated" within the meaning of the Act. It is easier to appreciate this connection once we examine the narratives that Senator Hatch and others employ to separate the acts of rape and domestic violence considered of "local" regulatory concern from those properly considered of "federal" regulatory concern.

Senator Hatch differentiates the roles of federal and state government in regulating intimate assaults by looking to the motivation animating the conduct. When such acts are motivated by hate, he reasons, they are properly matters of federal concern, but when they are motivated by love, they are not. As Senator Hatch succinctly put it: "If a man rapes a woman while telling her he loves her, that's a far cry from saying he hates her. A lust factor does not spring from animus. ${ }^{320}$ Restating this distinction, those acts of rape and domestic violence that are motivated by hate properly concern women's status as equal citizens of the United States, while those acts of rape and domestic violence that are motivated by love (or lust) are matters of purely local concern having no bearing on women's status as federal citizens or persons entitled to equal protection of the laws. The structure of this claim depends in part on an assumption that gender bias will manifest itself as race discrimination manifests itself: in an emotional state called "hate." ${ }^{\text {"321 }}$ But the claim also draws force from specifically gendered assumptions about intimate relations of the sort manifested in the discursive tradition of affective privacy. As in the nineteenth-century interspousal immunity cases, assertions about love and intimacy in a relationship rhetorically efface the violence of sexualized assault. We might distill the logic of this tradition to the following maxim: Where love

319. Cf. Naomi R. Cahn, Family Law, Federalism, and the Federal Courts, 79 IOWA L. REv. 1073, 1105 (1994) (noting similarity between Court's rhetoric confining family law to state tribunals and rhetoric confining women to private sphere).

320. See supra text accompanying note 306; see also Shalit, supra note 306, at 14 (reporting that Senator Dennis DeConcini, another Republican cosponsor of VAWA, agreed with Senator Hatch's interpretation).

321. Antidiscrimination law often refers to emotional or psychological states; but the law plays a crucial role in constructing the states of mind to which it refers. Our notions of discrimination are as importantly legal as they are psychological. 
is, law need not be. Intimacy occurs in a domain having no bearing on matters of citizenship.

I believe that federalism claims about VAWA's civil rights remedy are persuasive in significant part because they perpetuate traditional discourses of marital status in new idiomatic form. But one need not trace the lineage of these federalism claims to appreciate how the controversy over regulation of "gender-motivated violence" that we are examining will function to modernize discourses of gender status. A civil rights initiative intended to dismantle elements of a centuries-old status regime declares that violence against women is a form of sex discrimination, and soon thereafter becomes the object of political controversy. Those who wish to prevent enactment of the law raise a series of objections to it, couched in "legitimate, nondiscriminatory" reasons. They prevail to the extent of imposing an as yet indeterminate limit on the reach of the new antidiscrimination statute. Now courts are about to implement a law that requires them to determine which acts of rape and domestic violence are gender-motivated, hence violative of women's civil rights as equal citizens of this nation, and which acts of rape and domestic violence are purely local, presumably personal matters, attributable to love or lust, but not gender-based animus. The very struggle over the interpretation of VAWA's civil rights remedy will, of necessity, modernize gender status discourse, altering the rules and rhetoric governing intimate assaults in such a way as to make the distinctions VAWA draws "reasonable" for our day. Considered in larger historical perspective, controversy over the civil rights remedy contained in the Violence Against Women Act has set in motion a legal regime that will restate sexual assault law in the gender mores of American society at the dawn of the twenty-first century.

\section{CONCLUSION}

As this Article has demonstrated, status law is dynamic, and evolves in rule structure and rhetoric under the pressure of civil rights reform. In the nineteenth century, when judges repudiated a husband's common law prerogative to chastise his wife, they began to grant wife beaters a variety of formal and informal immunities from public and private prosecution. Just as the doctrine of chastisement was rationalized by rhetorics of hierarchy, this new regime of immunity rules was rationalized by rhetorics of interiority: by a discourse of affective privacy that invoked the feelings and spaces of domesticity to justify the law of marital status in an era of companionate marriage.

In short, as this Article has illustrated, emotions have a history, and their discursive roots can be traced-if only in small part- to the nineteenth-century courtroom, where the discourse of affective privacy served to make "reasonable" marital status doctrines when talk of marital unity no longer 
could. There, judges invoking the discourse of affective privacy translated the hierarchy-based chastisement doctrine into immunity rules couched in a more modern idiom: "If no permanent injury has been inflicted, nor malice, cruelty nor dangerous violence shown by the husband, it is better to draw the curtain, shut out the public gaze, and leave the parties to forget and forgive."322 The American antidiscrimination tradition pays scant attention to these chameleonlike qualities of status talk; it has reified the phenomena it calls "sex discrimination" and "race discrimination," without attending to their dynamic character. But this study of marital violence law from the days of Blackstone to current debates over the Violence Against Women Act demonstrates that status discourse is mutable, evolving as it is contested over the course of the centuries. If civil rights reform is to be effective, civil rights law must continually adapt, striving to remain in critical dialogue with the evolving rules and rhetoric of any status regime it aspires to disestablish. 67 Me. 304, 307 (1877) (tort immunity case). 
HeinOnline -- 105 Yale L.J. 2208 1995-1996 